







Memoirs of the Jboston Foctety of Matural bistory.

Volume 8, Number 3.

IDonograpbs on the Matural Distory of Thew Englano.

THE TURTLES OF NEW ENGLAND.

$e^{\text {tey }}$

BY HAROLD L. BABCOCK, M. D.

(1)

WITH SIXTEEN PLATES.

o $328557^{\text {sing }}$

tyational Hus

BOSTON:

PRINTED FOR THE SOCIETY WITH AID FROM

THE GURDON SALTONSTALL FUND.

APRIL, 1919. 



\section{CONTENTS.}

Leather-Back Turtle, Dermochelys coriacca (Linné) . . . . . . . . . . 333

Green Turtle, Chelonia mydas (Linné) . . . . . . . . . . . . . . . 338

Hawksbill Turtle, Eretmochelys imbricata (Linné) . . . . . . . . . . . . . . 342

Loggerhead Turtle, Caretta caretta (Linné) . . . . . . . . . . . . . 346

Snapping Turtle, Chelydra serpentina (Linné) . . . . . . . . . . . . . . 354

Musk Turtle, Kinosternon odoratum (Latreille) . . . . . . . . . . . . . . 359

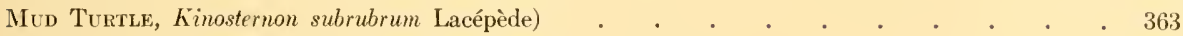

Painted Turtle, Chrysemys picta (Schneider) . . . . . . . . . . . . . . 368

Red-belited Terrapin, Pseudemys rubriventris (Le Conte) . . . . . . . . . 374

Geographical Terrapin, Graptemys geographica (Le Sueur) . . . . . . . . . 378

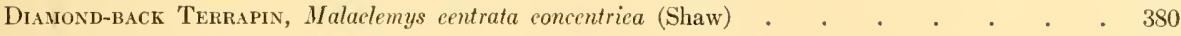

Spotted Turtle, Clemmys guttata (Schneider) . . . . . . . . . . . . . . . . . 397

Muhlenberg's Turtle, Clemmys muhlenbergï (Schoepfi) . . . . . . . . . . . . 401

Wood Tortoise, Clemmys insculpta (Le Conte) . . . . . . . . . . . . 403

Blanding's Tortolse, Emys blandingii (Holbrook) . . . . . . . . . . . . . 407

Box Tortoise, Terrapene carolina (Linné) . . . . . . . . . . . . . . . 411

Spiny Soft-shelled Turtle, Amyda spinifera (Le Sueur) . . . . . . . . . . . 419

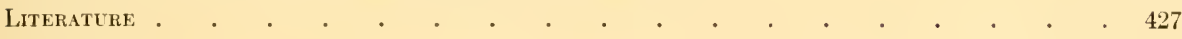





\section{INTRODUCTION.}

IN 1857, Agassiz wrote: "To tell American students that little is known of the habits of Turtles, the laying of their eggs, the growth of their young, etc., would perhaps excite a smile in those who, as boys, have been in the habit of collecting Turtles' eggs, egg-hunting being an occupation of which boys are fond all the world over. Yet so it is: what every inhabitant of the country may have seen again and again has not yet been collected in scientific works." The same conditions, although to a far less extent, still exist, and my aim in the present monograph has been to collect and classify what is known today of the life histories of New England Chelonians.

Mr. Samuel Henshaw, in 1904, prepared for the Boston Society of Natural History a list of the Reptilia of New England in which he recognized thirteen species of turtles. To that list I have here added four more: (1) Muhlenberg's Turtle, Clemmys muhlenbergii (Schoepf); (2) the Red-bellied Terrapin, Pseudemys rubriventris (Le Conte); (3) the Hawksbill Turtle, Erctmochelys imbricata (Linné); and (4) the Mud Turtle or Box Terrapin, Kinosternon subrubrum (Lacépède); making a total of seventeen species for New England. Caretta kempii, the so-called Bastard Turtle of Garman, whose range is given in Stejneger and Barbour's Check List of North American Amphibians and Reptiles (1917, p. 123) as extending "accidentally to the coast of Massachusetts," is not included in this monograph; neither is Chrysemys marginata, reported by Bumpus from Middleboro, Mass.

Three specimens of Clemmys muhlenbergii were collected by Alexander Agassiz at Newport, R. I., and presented on September 23, 1902, to the Museum of Comparative Zoölogy at Cambridge, where they now are. This record has never before been published. While it is possible that these were escaped caged animals, it is not at all likely. This turtle is not generally abundant throughout its range and often occurs locally as in this instance. "Pseudemys rubriventris occurs in certain fresh-water ponds in Plymouth County, Massachusetts, where it seems to remain isolated. This record I reported (Babcock, 1916a) in Copeia, in December, 1916. Eretmochelys imbricata was reported from Woods Hole, Massachusetts, in 1909, by F. B. Sumner (1909). Kinosternon subrubrum is of doubtful occurrence in New England, although it should be found in the southern part. Hitchcock (1833) includes it in his Catalogue of Reptiles of Massachusetts. This record is questioned by Holbrook (1842, vol. 1) who thinks he confused it with Kinosternon odoratum. Linsley reports one specimen taken at Stratford, Conn., in 1843. I, therefore, include it provisionally. As the total number of species of turtles recognized in North Anerica is sixty-one, New England is well represented.

Turtles constitute the order Testudinata of the Class Reptilia, (subclass synapsida) 
representatives of which in the present age are but pigmies as compared with the huge reptilian forms that roamed the earth during the Mesozoic and earlier Tertiary periods when they reached their greatest development. In fact, there are only two groups of living turtles that at all suggest this wonderful reptilian age: (1) the Giant Land Tortoises of the Galapagos Islands (named Galapagos = Tortoise Islands by early Spanish explorers) and of the Aldabra Islands, adult specimens of which have been known to weigh several hundred pounds; and (2) the Leatherback or Trunk Turtle (a marine species) which is included in the New England fauna. Speaking of the order as a whole, Williston (1914, p. 216) says: "No order of reptiles of the past or present is more sharply and unequivocally distinguished from all others than the Chelonia or Testudinata. No order has had a more uniformly continuous and uneventful history. None now in existence has had a longer known history, and of none is the origin more obscure. The first known members of the order, in Triassic times, were turtles in all respects, as well or nearly as well adapted for their peculiar mode of life as are those now living, and were they now living they would attract no especial attention from the ordinary observer and but little from the naturalist. From time to time some have gone after better things, and have come to grief, but the main line has remained with fewer improvements, fewer evolutional changes, than any other group of higher vertebrates."

Gadow (1901, p. 312) describes turtles as "terrestrial or aquatic, pentadactyle reptiles, with walking limbs or with paddles; ribs with capitular portions only, two sacral vertebrae, humerus with entepicondylar foramen, pubes and ischia forming symphyses, quadrate bones fixed, jaws without teeth, but with cutting horny sheaths. Trunk encased in a bony shell, composed of numerous dorsal and ventral dermal bones, forming a carapace and a plastron, which may or may not be covered with horny shields. Copulatory organ unpaired, cloacal opening more longitudinal than round, never transverse. Oviparous." The skull is more solid and compact than in other reptilian orders. The carapace (upper half of shell) and plastron (lower half of shell) are usually connected by a bony bridge. In some species, however, a ligamentous hinge divides the plastron so that one or both parts are movable as in the Box Tortoise. In the genus Cinixys (of the Old World) a similar hinge extends across the carapace, the posterior portion being movable. The neck, which may be completely or only partially withdrawn into the shell, is an important factor in classification, for in some forms it is simply folded sideways (Pleurodira) while in others it is retracted in a sigmoid curve in the vertical plane. The various shades and degrees of colors (black, yellow, or red) in turtles are due to a pigment formed in the Malpighian layer of the skin. The digestive apparatus is simple. The relative length of the different portions of the intestinal tract in different species varies to a considerable extent, so much so that it also becomes a factor in classification. Louis Agassiz in his Contributions to the Natural History of the United States of America (1857, vol. 1, p. 279) gives an interesting table illustrating some of these variations. Agassiz calls 
especial attention to "Cistudo" which, while superficially a land tortoise, is classed by him as an Emydian by means of its intestinal measurements. The length of the whole intestine in comparison with the length of the shell of the animal is proportionately greater in herbivorous than in carnivorous turtles. The heart is three-chambered and its rate of contraction slow. The roice in most turtles is only slightly developed, a faint piping note being emitted, chiefly during the mating seasons. The sea turtles are more efficiently equipped, especially the Lcatherback Turtle, one of whose Latin names is sphargis (coming from the Greek, $\sigma \phi$ a préc, to make a noise) since it is said to give vent to loud cries or barks when wounded or being captured (Sears, 1Ss6).

The respiration of turtes is interesting in that owing to the bony and unyielding chest wall there can be no expansion and contraction, necessitating the pa-age of air under pressure into the lungs. This is accomplished partly by means of the hich!y deteloped hyoidean apparatus (the air being swallowed or pumped into the lungs) and partly by the neek and limbs which act as pistons when drawn in or out. The fullowing is a very interesting table showing the capracity of the lungs as cmpared with the weight of the body in various species of turtles, after L. Agassiz (1857, vol. 1, p. 283).

Capacity of the Lungs compared with the IVeigle of the Body.

\begin{tabular}{|c|c|c|c|c|}
\hline Species & Mode of Life & $\begin{array}{l}\text { Wt. of the } \\
\text { borly }\end{array}$ & $\begin{array}{l}\text { Capacity of } \\
\text { the lungs }\end{array}$ & $\begin{array}{l}\text { Length } \\
\text { of the } \\
\text { Carapace }\end{array}$ \\
\hline Testudo polyphomus (Gopher). Female & $\begin{array}{l}\text { On dry ground and in sand- } \\
\text { holes }\end{array}$ & 9.5 ounces & $35 \mathrm{cu}$. in. & $101 \frac{1}{2}$ inches \\
\hline $\begin{array}{l}\text { Cistudo trimguis (Three-toed Box- } \\
\text { Turtle). Female }\end{array}$ & $\begin{array}{l}\text { In dry woods, under leaves, } \\
\text { etc. }\end{array}$ & 19 & $17 \frac{3}{4}$ & $6 \frac{3}{4}$ \\
\hline $\begin{array}{l}\text { Ptychemys rugnsa (Emys rubrientris) } \\
\text { (Red Terrapin). Female }\end{array}$ & In water and on land & 62 & $22 \frac{1}{2}$ & 11 \\
\hline $\begin{array}{l}\text { Cinosternon pennsylvanicum (Mul } \\
\text { Turtle). I'emale }\end{array}$ & In water and mud & 8 & $\frac{1}{2}$ & "* \\
\hline $\begin{array}{l}\text { Chelydra serpentina (Anapping Turtle) } \\
\text { Iale. }\end{array}$ & In water and mud & 65 & 7 & 10 \\
\hline $\begin{array}{l}\text { Trionyx ferox (Soft-shelled Turtle). } \\
\text { Fenale }\end{array}$ & In water and mud & 76 & $1^{\frac{1}{2}}$ & 13 \\
\hline
\end{tabular}

Pulmonary respiration is supplemented by two accessory systems: (1) a pair of thinwalled, highly vascularized anal sacs which are from time to time emptied and refilled with water, and (2) in some aquatic turtles by vascularized areas suggestive of gills, in the pharyngeal region. During hibernation (regularly performed in this latitude) pulmonary respiration is entirely suspended. ${ }^{1}$

\footnotetext{
Turtle").

${ }^{1}$ Aestivation has also been observed in eertain species (see G. P. Engelhardt, 1916, on "Burrowing Habits of the Box
} 
In view of the fact that the terms "turtle," "terrapin," and "tortoise" are used loosely and more or less interchangeably, Hornaday (1914) has suggested that: (1) all Chelonians of the land only should be called tortoises; (2) all Chelonians of fresh water should be called terrapins; (3) all Chelonians of the sea should be called turtles.

In "psychological development" or intelligence turtles stand at the head of their class, occupying a position between birds and batrachians. As this is also true of their structure, the formula that the rank of an order structurally, expresses at the same time the range of its mental development, is here illustrated.

The limits of distribution for turtles are roughly between 50 degrees North latitude in the western hemisphere, 56 degrees North latitude in the eastern hemisphere, and 36 degrees South latitude. Marine turtles, however, have been known to pass beyond these limits. New England includes the northern limit of distribution of most of the Chelonia of eastern North America, only a few species extending still farther northward.

In their habits turtles are diurnal, except during oviposition. Land tortoises are very slow and deliberate in their movements while many aquatic species are very agile and very shy. Turtles remain throughout their life in the same general locality, with the notable exceptions of the marine species, which are great wanderers. Their tenacity of life is remarkable. Specimens have been kept alive for a year without food or water; others have been frozen solid in ice, thawed out, and still survived. They attain to great age. Gilbert White's famous tortoise (Testudo ibera) lived nearly sixty years. A giant tortoise (T. sumerrei) was in captivity at Port Louis when the island of Mauritius became a British possession in 1810 . It was still alive in 1909, although nearly blind, being kept in the grounds of the barracks of the garrison. Undoubtedly some of the giant land tortoises of the Galapagos and Aldabra Islands are the oldest living animals on earth. Determining the age of turtles from dates previously cut in their shells may be very misleading.

The food of the Chelonia varies with the species. Land tortoises and some marine turtles are strictly herbivorous, while other groups are carnivorous or omnivorous.

All Chelonians are oviparous, the eggs being white in color, round or oval in shape. They are deposited in the ground, and are hatched by the heat from the sun. The young are entirely self-supporting from birth.

The natural enemies of turtles are comparatively few in number and it is a continual source of wonder to naturalists that the fresh-water terrapins, especially, should be so shy and eternally vigilant. In the South, crocodiles and alligators devour them, and in South America the large cats hunt them. Sea turtles are subject to attacks from sharks and other predaceous fish. By far the greatest factor in depleting the number of these animals is the destruction of their eggs. These constitute a rare delicacy for skunks, raccoons, weasels, to say nothing of the tremendous inroads made each year in certain parts of the world by man. 
The following is a striking account illustrating the degree of egg destruction for food and oil by the natives on the River Amazons, from the intensely interesting work by $\mathrm{H}$. W. Bates (1863, vol. 2, p. 270): "By the morning of the 17 th, some 400 persons were assembled on the borders of the sandbank; each family having erected a rude temporary shed of poles and palm leaves to protect themselves from the sun and rain. Large copper kettles to prepare the oil, and hundreds of red earthenware jars, were scattered about on the sand.

"The excavation of the taboleiro, collecting the eggs and purifying the oil, occupied four days. All was done on a system established by the old Portuguese governors, probably more than a century ago. The commandante first took down the names of all the masters of households, with the number of persons each intended to employ in digging; he then exacted a payment of 140 reis (about fourpence) a head, towards defraying the expense of sentinels. The whole were then allowed to go to the taboleiro. They ranged themselves round the circle, each person armed with a paddle, to be used as a spade, and then all began simultaneously to dig on a signal being given - the roll of drums - by order of the commandante. It was an animating sight to behold the wide circle of rival diggers throwing up clouds of sand in their energetic labours, and working gradually towards the centre of the ring. A little rest was taken during the great heat of mid-day, and in the evening the eggs were carried to the huts in baskets. By the end of the second day, the taboleiro was exhausted: large mounds of eggs, some of them four to five feet in height, were then seen by the side of each hut, the produce of the labours of the family.

"In the hurry of digging some of the deeper nests are passed over; to find these out the people go about provided with a long steel or wooden probe, the presence of the eggs being discoverable by the ease with which the spit enters the sand. When no more eggs are to be found, the mashing process begins. The egg, it may be here mentioned, has a flexible or leathery shell; it is quite round, and somewhat larger than a hen's egg. The whole heap is thrown into an empty canoe and mashed with wooden prongs; but sometimes naked Indians and children jump into the mass and tread it down, besmearing themselves with yolk and making about as filthy a scene as can well be imagined. This being finished, water is poured into the canoe, and the fatty mess then left for a few hours to be heated by the sun, on which the oil separates and rises to the surface. The floating oil is afterwards skimmed off with long spoons, made by tying large mussel-shells to the end of rods, and purified over the fire in copper kettles.

"The destruction of turtle eggs every year by these proceedings is enormous. At least 6000 jars, holding each three gallons of the oil, are exported annually from the Upper Amazons and the Madeira to Pará, where it is used for lighting, frying fish, and other purposes. It may be fairly estimated that 2000 more jars-full are consumed by the inhabitants of the villages on the river. Now, it takes at least twelve baskets-full of eggs, or about 6000 , by the wasteful process followed, to make one jar of oil. The total number of eggs annually destroyed 
amounts, therefore, to $48,000,000$. As each turtle lays about 120 , it follows that the yearly offspring of 400,000 turtles is thus annihilated."

Certain large birds of prey have been observed to drop turtles from a great height on rocks in order to break the shell. This fact may have been the foundation for the ancient fable of the unfortunate poet Eschylus, who was said to have been killed by a tortoise which was dropped on his head from a great height by an eagle.

The turtle occupied an important place in the life and superstitions of the North American Indians. The flesh was used for food and the shells as receptacles. The eggs were also eaten. The "tortoise-shell drum" was used by the medicine men of the tribes as an instrument of magic (Thwaites, ed., 1901, vol, 20, p. 306). With it they attempted to prolong life and heal the sick. This drum was made by cleaning and drying the shell with the head, limbs, and tail intact. Porcelain beads or pebbles were then put inside and the shell pierced with a stick which served as a handle when shaking it. The Missionary Monks of Brazil ate turtle during Lent in recognition of the virtue of its amphibious habits. On the other hand, in China, to be called a "turtle" is one of the greatest of insuits, because of the supposed infidelity of the animal.

From an economic standpoint, turtles are becoming increasingly important in the modern world. A description of egg collecting for oil manufacture has been given. Oil is also obtained from the fat taken from certain large land tortoises. The fles of certain species of sea turtles and fresh-water terrapins is coming rapidly into favor as food, notwithstanding the Biblical mandate to Moses and Aaron that the flesh of the tortoise is "unclean" (Lev. 11:29). The artificial propagation of the Soft-shelled Turtle (Amyda japonica) has been successfully carried on in Japan for years and has more recently been attempted in the L'nited States along the South Atlantic coast with several forms of the Diamond-back Terrapin. The sea turtle, Eretmochelys imbricata, furnishes the popular "tortoise-shell" of commerce, an account of which will be found in the subject matter dealing with that species.

I have adopted the nomenclature of the recently published Check List of North American Amphibians and Reptiles by Stejneger and Barbour (1917).

To Dr. Glover M. Allen of the Boston Society of Natural History, and to Dr. Thomas Barbour of the Museum of Comparative Zoölogy at Cambridge, I wish to express my thanks for their help and interest. 


\title{
Family DERMOCHELYDID_E.
}

Dermochelys coriacea (Linné).

Marine Leather Turtee; Luth: Leathery Turtle; Leather-back Turtee; Trunk Turtle; Harp Turtle; Lyre Turtle.

\author{
Plate 17, Figs. 1-4.
}

Testudo coriace Linné, Syst. Nat., ed. 12, 1766, vol. 1, p. 350.

Dermochelys coriace Boulenger, Cat. Chel. Brit. Mus., 1s.59, p. 10.

The Leatherback Turtle is the largest of the living Chelonians. It is unique among turtles in that the vertebrae and ribs are not fused with the carapace, but are free within it, thus constituting it a distinet suborder. Igassiz compares its form to a "flattened eone with angular sides, to which are appended in front a large head with a pair of larger naked paddles, and behind a smaller pair of rery broad rudders." . Inhn Ford has related the experiences of some seamen who onee captured a Leathrback Turtle and could not identify it, the eaptain maintaining that it was "Old Nick" himself. "Lnfortunately, horrever, for their future prospects," he says, "it proved to belong to the species under" consideration, 'more's the pity,' perhaps."

Size.- Turtles measuring nine feet in total length have been reported by fishermen, but doubtless these measurement were somewhat exaggeraterl. Six or seven feet is prohably a reliable average for most adults. Gador: (1901, p. 333) states that the liggest specimen in the British Jiuseum is about six and one-half feet long from the nose to the end of the shell, which latter is about four feet. Ditmars $(1907$, p. (i) describes one in the American NIuseum of Natural History with a total length from snout to end of tail of six feet, length of carapace five feet one inch. Sears (1S56) measured one with a total length of seren feet thice inches. The largest specimen in the Museum of the Boston sinciety of Natural History has a total length of eighty-three inches and carapace of fifty-seren inches; outer curve of arm from corner of earapace, forty-one inches.

Weight.-Numerous weight records exist, but as many of these are estimated, they are of relative value only. I have omitted weight records approximated by fichermen and quoted in the newspapers from time to time as being unreliable and too high. Even Agassiz's statement that he has "scen specimens weighing over a ton," I believe to be exaggerated. Three Leatherbacks taken in Long Island sound during the summer of 187.5 wcre all said to weigh "about 1000 pounds." Definite and reliable records do exist, however, such as the following: a specimen weighing 740 pounds by Hornaday (1914, vol. 4, p. 51); one by Ditmars (1907, p. 6) weighing 715 pounds; one by Boulenger (1914, p. 15) weighing "just orer 1,500 pounds." 
The weight of the specimen from No Man's Land in the Museum of the Boston Society of Natural History was about 600 pounds.

Color:- Dark brown, greenish, or blackish, sometimes uniform, sometimes spotted with yellow.

Description.- The vertebrae and ribs are not fused with the carapace. There are no epidermal shields, but the body is covered with a thick, smooth, leathery skin. The limbs are transformed into paddles. The neck is not retractile. The shell has twelve longitudinal ridges, seven above and five beneath.

The chief peculiarity of this turtle consists in the structure of the shell and arrangement of the plates. The dorsal and ventral halves are continuous, forming one unbroken case. This is composed of many irregular bony plates, fitting closely together and giving the shell a "beautiful mosaic appearance." The converging longitudinal ridges are formed by lateral rows of larger plates, forming angles in the bony shell. There is no contact between the shell and the internal skeleton except in an articulation between the nuchal bone and the eighth cervical vertebra. Between the epidermis and the shell there is a one-inch layer of fatty tissue. The tail is short, although containing about twenty vertebrae. The front flippers are very long and large. None of the fingers projects free, hence none has a nail. In another important respect the Leatherback and its few fossil relatives differ from all other turtles. This is in the fact that the parietal bone does not send a plate clownward in front of the exit of the trigeminal nerve to join the pterygoid (Hay). For a very detailed work on the skull characters, see Das Kopfskelet von Dermochelys coriacea L., by Ludwig Nick (1912).

Origin and Development.-The position of this species in the evolutionary system has been a much debated subject. One group of naturalists considers it the sole remnant of a primitive group, while another looks upon it as a most highly specialized descendant of the Chelonidae.

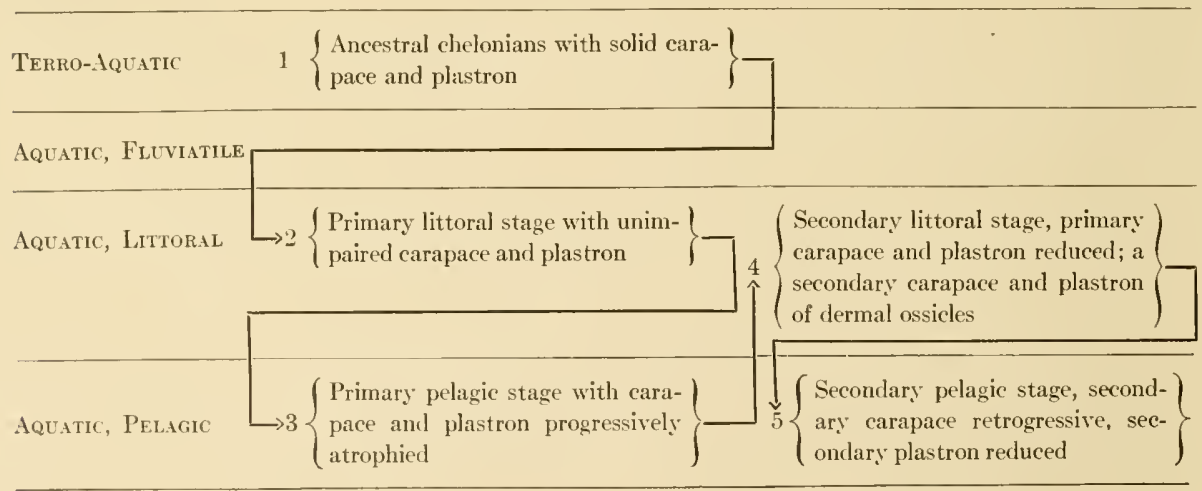


The foregoing diagram (after Osborn) illustrates the theory of Dollo in regard to the origin of the Leatherback. This theory as explained by Osborn is, "that these animals originate in armoured land forms with a solid bony shell, and pass from the terrestrio-aquatic into the littoral and then into the pelagic zone, in which the solid bony shell, being no longer of use, is gradually atrophied. After prolonged marine pelagic existence these animals return secondarily to the littoral zone and acquire a new armature of rounded dermal ossicles which develop on the upper and lower shields of the body. The animals (Sphargis) then for a second time take up existence in the pelagic zone, during which the dermal ossicles again tend to disappear."

Geographic Distribution.- Holbrook (1842, vol. 2, p. 47) dismisses this subject with the simple statement: "The Sphargis coriacea inhabits the Atlantic Ocean." It is certainly pelagic, ranging over all the tropical and semitropical seas. It occasionally visits the coasts of Great Britain, France, and the Mediterranean, but is more common in the western Atlantic from Florida to Brazil, - the West Indies, according to Agassiz, being its home. It has been taken off the coast of Japan and in the Indian Ocean.

New England Records. - These turtles from time to time travel north in the Gulf Stream, leaving it as it turns eastward, thus coming in contact with colder waters, and so appear occasionally along our middle Atlantic and New England coasts, often in a chilled and benumbed condition. Hence it becomes of faunistic importance in this region. It has been recorded as follows ${ }^{1}$ :-

1811 - Location uncertain.

1816 - Sandy Hook (Barnum's American Museum).

1824 - Massachusetts Bay (first New England record; specimen now in Society's Museum).

1826 - Long Island Sound.

1848 - Near Cape Cod.

1852 - One washed ashore at Nahant, Mass.

1866 - One captured off coast of Maine.

1875 - One at Stonington, Coun. (July). It was seven feet long and weighed about 1000 pounds. Sent to the Smithsonian Institution.

One at Long Branch. Taken with a harpoon as it lay asleep in the water, "and by it he dragged the boat several miles."

One taken between New London and Montauk Point.

1876 - One at Stonington, Conn. (July).

1877 - One at Naskeag Point, Maine.

1878 - One at Narragansett Bay (Brown Univ.).

1878 - One off Cape Elizabeth, Maine (Sept.).

1879 - One off Marion, Buzzards Bay, Mass.

1850 - One at Annisquam, Mass.

One off Cape Ann, Mass.

1882 - One at Gloucester, Mass.

One "near the coast of Essex Co.," Mass. (Peabody Museum, Salem).

${ }^{1}$ Certain doubtful records made by fishermen and others have not been included in this list. 
1885 - One "near Boston," Mass.

One at Portland, Maine.

One at Rockport, MIass. (Aug. 25) (Peabody Museum, Salem).

$18 \$ 6$ - Two in the ricinity of Southeast Point, Block Island, R. I. (about July 30).

1 \$. 91 - (?) One taken in fish trap in Buzzards Bay, near Woods Hole (wt. 1400 pounds).

1907.-- One taken a few miles south of No MLan's Land, Mass.- "Got fouled in a fishing dory's anchor rope."

(Early July.) Specimen now in Museum of Boston Society of Natural History.

1908 - One taken off Rockport, Mass. (.Jug.).

One landed at Bath, Maine.

1909 - One near Portland, Me. (Now in Academy of Natural Sciences, Philadelphia, Pa.)

1917 - One at Corporation Point, Cape Cod, Mass. Weight 550 pounds.

In the Museum of the Boston Society of Natural History, in addition to the specimens from No Man's Land and Massachusetts Bay, is one labeled Buzzards Bay, but with no additional data.

Individual Range.- Its wide distribution taken together with its great powers of locomotion have led to the belief that single individuals wander over tremendous areas.

Numbers.- It is nowhere common.

Breeding.-Agassiz (1557, vol. 1, p. 373) says: "It breeds regularly every year in the spring, on the Bahamas, on the Tortugas, and on the coast of Brazil." It also breeds, according to Boulenger, off the coast of Tenasserim, and at the entrance to the Klang Straits, where "they congregate in orcler to deposit their eggs, each female depositing some three or four hundred."

Habits. - The great powers of locomotion of this turtle have been spoken of, it being the most thoroughly aquatic turtle known. It apparently approaches the shore only to deposit its eggs; otherwise it is entirely marine. Its strength is illustrated by the following interesting account of the capture of a specimen at Santa Barbara in 1905, by G. W. Gourley: "The turtle was first seen swimming on the surface about two miles off shore. I went after it, accompanied by a boy, in an eighteen-foot sailing boat. On approaching the turtle I dropped the tiller and got forward with the gaff hook, swung over the side, and got the hook fast in the leathery part of his neck. He immediately sounded, and ran out the full length of the line about two hundred feet - towing the boat about half a mile further out to sea. He then came to the surface and we pulled up close to hin again. When he caught sight of the boat he turned and came toward us and threw his flippers over the gunwale of the boat, nearly capsizing her. I climbed up on the upper side, and shoved him off with an oar, the end of which he grabbed and bit off like a piece of cheese. His movements were very swift; using his foreflipper he could turn almost instantly from one side to the other and his head would project about eighteen inches from the body. I succeeded at last in throwing a noose over his head, and later, by attracting his attention in the opposite direction, got ropes round both flippers, finally having five lines on him, and started to tow him towards the shore. We were from 
11:30 A. M. until 4 P. MI. in finally landing him. When about half way to shore he suddenly turned, and made a break out to sea, towing the boat stern first, with all sail drawing full, for several hundred yards, with little effort. He emitted at intervals a noise somewhat resembling the grunt of a wild boar" (E. G. Boulenger, 1914, p. 14).

Sears (1886) describes the behavior of a captured specimen as follows: "The motions of this turtle were remarkably quick for so large a creature when out of its natural element; it moved around the room in which it was confined, unsetting barrels, tables and the stove as easily and as quickly as a Texas wild steer would have done, causing a general commotion. In its struggles while being secured (which was accomplished by lashing the anterior flippers together on the under side) it uttered a sound of great volume, an indescribable kind of noise such as is heard sometimes at a menagerie. Its eyelids open vertically or in the opposite direction to that of other turtles. Unlike other turtles, this species cannot turn their head sidewise or move it up or down, so that we were perfectly safe from his vicious snaps while securing his flippers."

The fact that only large, adult, or very young individuals of this species have been taken would suggest that during growth these turtles either remain far out to sea or else are so shy that they dive at the slightest sign of danger.

Food.- Sea-weeds, crustaceans, mollusks, and fishes are considered its ehief diet. Agassiz assumed the species was carnivorous from the form of the jaws. Gadow is inclined to this view. Nothing, apparently, is definitely known regarding its food habits. It.is probably omnivorous.

Enemies.- It is difficult to imagine this giant of the seas in danger from any but the largest predaceous fish. Man does not persistently hunt it.

Economic Importance.- Its flesh has no market value, being considered unfit for food. The thick fatty blubber-like coating, overlying the bony carapace contains about one pint of oil for every square foot (Hornaday).

It may be of interest to note that one of the early names suggested for this turtle, Testudo lyra, is said to have reference to the myth that the shell was used by Mereury in his construction of the lyre. 


\title{
Family CHELONIIDAE.
}

\author{
Chelonia mydas (LINNÉ). \\ Green Turtle; Edible Turtle. \\ Plate 18, Figs. 1, 2.
}

Testudo mydas Linné, Syst. Nat., ed. 10, 175S, vol. 1, p. 197.

Chelonia mydas Schweigger, Arch. Naturw. Math., Königsberg, 1812, vol. 1, pt. 3, p. 412.

The Green Turtle, so called because of the greenish color of its fatty tissue, is the most highly prized of all our sea turtles as an article of food.

In appearance it in no way resembles the Leatherback Turtle, belonging to an entirely separate family, and from the Loggerhead Turtle it is easily distinguished by its smaller head and more cleanly-cut lines. Its form is that of a "heart flattened on one side, from the broad end of which projects the ... head . . ., and from the widening side of which protrude, in front, wing-like, scaly flappers, and below the narrow part of which hang another pair of broad, short, scaly rudders" (Agassiz).

Size.- Large specimens of this species have weighed five or six hundred pounds, but of late the average weight of turtles received in the American markets is said to be about fifty pounds. The shell of a large specimen will reach nearly four feet in length.

Color.- The carapace is pale olive or brownish, mottled or banded with yellow. The plastron is light yellow or lemon.

Description.- This turtle belongs to an entirely separate suborder (Thecophora) from the Leatherback. In this group the thoracic vertebrae and ribs are united, and covered with a series of median (neural) and a paired series of lateral (costal) plates. Also the parietals are prolonged downward, meeting the pterygoids either directly or by the interposition of an epipterygoid. In this family the pelvis is not fused with the shell. The carapace is quite smooth in adult specimens, (keeled in young ones), the twenty-five marginal shields forming a smooth or slightly serrated border. Four pairs of costal shields are present. The head is covered with smaller shields, brownish or olive in color. The horny beaks of the jaws have denticulated outer edges. The extremities are covered with shields and with (usually) one blunt claw on the first digit. The neck is only slightly retractile and bends in an S-shaped curve in the vertical plane.

Geographic Distribution.- This turtle has a wide range, inhabiting tropical and semitropical waters throughout the world. It has been reported as especially numerous about the West Indies, the Island of Ascension, Mosquito Coast, the Bahamas, Bay of Honduras, 
along the coasts of Guiana and Brazil, within the Gulf of Mexico, and off the coast of Florida. Like the Leatherback Turtle it wanders north in the Gulf Stream and is an occasional visitor to our northern coasts.

New England Records.- Henshaw (1904) gives no records, but states: "Massachusetts to Connecticut." They are occasionally reported along the southern New England coast. One was taken in New Bedford Harbor, Mass., in late September, 1878, and another reported off Cohasset, Mass., in October of the same year. The weight of the latter was estimated at seventy-five pounds (Forest and Stream, 1878, vol. 11, p. 244).

Linsley (1843) reports two specimens taken in the Housatonic River, one at its mouth and one "seven miles up." Numerous Long Island Sound records exist, one by DeKay (1842) being in September, 1840. It might be expected to occur in Buzzards Bay, but is not mentioned in the Biological Survey of Woods Hole and Vicinity by Sumner, Osburn, and Cole (1913). There is no specimen of this species in the museum of the Boston Society of Natural History.

Environment.- While the turtle is known to frequent deep seas, it is also taken in shallow channels where it feeds in the quiet waters.

Numbers.- These turtles were formerly common about their favorite haunts, but owing to the continual onslaught of turtle-hunters, their numbers (especially of large specimens) are rapidly decreasing.

Breeding.- Approaching shore for breeding purposes only, the females deposit their eggs on "sandy shores of desolate islands or uninhabited banks of certain rivers." They have been observed to breed at the Tortugas Islands. Audubon (Ornithological Biography, 1835, vol. 2, p. 371) gives the following account of their actions at such times: The female arrives by night, slowly and cautiously she approaches the shore, and if undisturbed, crawls at once over the sand above high water mark; here with her fius she digs a hole one or two feet deep, in which she lays her eggs, between one and two hundred in number. These she arranges in the most careful manner, and then "scrapes the loose sand back over the eggs, and so levels and smooths the surface, that few persons on seeing the spot could imagine any thing had been done to it." The nest is not revisited by the turtle, the eggs being incubated by the sun's rays and the young instinctively seeking the water as soon as hatched. They are entirely selfsupporting from birth.

Holbrook (1842, vol. 2, p. 29) makes the statement that "two or three times in the season does the female return to nearly the same spot and $d_{c}$. osit nearly the same number of eggs, so that the whole amount annually would be four or five hundred"; a statement which is quite properly challenged by Agassiz as being incorrect. The whole operation of digging, laying, and filling up the nest is said to last about two hours. The season for breeding varies with the geographical location. In the West Indies and Straits of Malacca it occurs from April 
to June; on the coast of West Africa, from September to January. The young of this species are sometimes called "chicken turtles."

Habits.- This turtle is very graceful in the water and is fond of sleeping on the surface, in which condition it is often captured by turtle hunters. Holbrook was impressed with the fact that "animals so low in the scale of creation, should have the instinct to return to their haunts from great distances, hundreds and even thousands of miles." He says: "Dr. Strobel informed me that several Turtles were captured at Tortugas, marked, and carried to Key West, there confined in a turtle-pen or 'crawl,' which was destroyed by a storm; the animals escaped, and in a few days were recaptured at the Tortugas." Ditmars (1907, p. 9) relates the following regarding the actions of a captive Green Turtle: "From a lot of turtles that had been shipped north and were lying upon their backs for fully a week, the writer selected a specimen weighing forty-five pounds and placed it in a large tank containing manufactured salt water enough salt added to fresh water to give it a brackish taste. On the second day in the tank the turtle began feeding, greedily taking large pieces of raw fish; it also ate the commoner kinds of sea-weed. Under these conditions it lived for nearly two years and would have thrived longer had it not been attacked by a small crocodile. The tank was ten feet long and eight feet wide and the animal swam about freely and gracefully; its deliberate motions, slow turns, the occasional stroke of the flippers and slow, gliding progress, were movements strikingly suggestive of the leisurely flight of a hawk or a turkey buzzard. The reptile seldom crawled upon the bottom of the tank, but skimmed over the gravel by a few inches; occasionally it came to the top, when it would expel the air in its lungs with a sharp hiss; the intake of air was more leisurely."

Food.- From the above account it appears that this turtle under certain conditions is omnivorous, but in its natural state is probably herbivorous. Audubon (Ornithological Biography, 1835, vol. 2, p. 374) describes their feeding on marine plants, especially one called turtle-grass (Zostera marina); this they cut near the roots to procure the most tender and succulent part, which alone is eaten, while the rest of the plant floats to the surface and is there collected in large fields, "a sure indication that the feeding ground of the Green Turtle is near." They are said to roll these plants, together with the adherent mud, into balls "of the size of a head, and these balls, receding with the tide, are followed by the turtles." Purslane (Portulacca oleracea) and various marine plants have formed the diet of captive specimens.

Enemies.- Man is their greatest enemy. The turtles are hunted at all seasons of the year, but during the breeding season the greatest inroads are made. Owing to the fact that while laying their eggs the turtles can be approached without caution, they have been taken at these times by the hundreds. Audubon cites an instance of 800 having been taken in one year by one man to be sold for food. When taken in this way, the animals are turned on their back, and are then unable to re-turn. This turning of turtles has been described as a "cruel 
and wanton operation," as doubtless it is in cases where the turtles are left to perish, but the following quotation explains its necessity from an anatomical standpoint: "Although the treatment has been generally condemned as cruel, it is a necessity in keeping the turtles alive unless they can be placed in capacious tanks of sea water-an expensive process for the markets. The plastron is not so rigidly constructed as with the fresh-water turtles. If examined, it will be found quite pliable, offering little of the bony support of most chelonians. This is not a defect in the structure, as the sea turtles never find it necessary to rest their weight upon the plastron except in the brief trips shoreward to lay their eggs. Thus, if these animals are placed in a 'normal' position when out of the water their great weight presses the plastron upwards against the lungs and other internal organs, causing speedy death" (Ditmars, 1910, p. 48). These turtles are taken while in the water, with nets, harpoons, and in various other ways.

"In some parts of the world the natives follow them in a boat, and when they espy a turtle crawling along the bottom, a man, attached to a rope, dives in, clasps it, and is brought up by his companions together with his prey. Turtles are fond of basking asleep, floating on the surface, and they are then harpooned from a stealthily approaching boat. The most original mode of catching them is that used by the natives of Torres Straits, Madagascar, and Cuba. The turtle-fishers go out in the boat to a spot frequented by grazing turtles; a long string is tied to the tail of a fish, Echeneis, a member of the Mackerel family, and the Echeneis, anxious to get away to protective shelter, makes for a turtle, and attaches itself to the turtle's plastron by means of the large sucking apparatus on the top of its head and neck-region. The men are guided by the string, and the turtle is gently coaxed up towards the surface or followed into shallow water, where it is either harpooned or dived for. It is curious that this use of the Echeneis exists in such widely separated parts of the world, the natives of which cannot have any knowledge of each other" (Gadow, 1901, p. 382).

The nests are also robbed. These are discovered by probing in the sand with rods. In this way thousands of eggs are obtained. Besides man, raccoons have been known to uncover and destroy the eggs. Enemies of young turtles are rapacious aquatic birds and ravenous fishes.

Economic Importance. - The flesh of this turtle is highly esteemed as food practically the world over, at least, wherever it can be obtained. It is used not only in the famous "turtle soups" but as steaks and in other forms. It has an agreeable flavor, is tender, and fine-grained. The ineat is dark colored. The shell has no commercial value. Oil is produced from the eggs. 


\section{Eretmochelys imbricata (LINNE). \\ Hawksbill Turtle; Shell Turtle. \\ Plate 19.}

T'estudo imbricata Linné, Syst. Nat., ed. 12, 1766, vol. 1, p. 350.

Eretmochelys imbricata Agassiz, Contr. Nat. Hist. U. S., 1857, vol. 1, p. 381.

The Hawksbill Turtle is the smallest, ${ }^{1}$ most beautiful, and most valuable of the sea turtles. It is unique in that the shields of the carapace are imbricated.

Size.- The average length for the carapace itself is about two feet, specimens measuring two and one-half feet being considered large. The length of the largest shell in the British Museum is $85 \mathrm{~cm}$. or 34 inches.

Weight.- An average turtle will weigh twenty or thirty pounds.

Color.- The shields of the carapace are colored a "rich, warm, translucent yellow, dashed and spotted with rich brown tints." The plastron is light yellow. The head and flippers are covered with small shields of browu or black with narrow margins of yellow.

Description.- This turtle is characterized by the imbricated shields of the carapace, which overlap from before backward, except in very old specimens where the shields are juxtaposed. The neural and costal shields are strongly keeled in young specimens. The marginal shields form a sharply serrated edge, more pronounced in the posterior portion of the shell. The horny jaws with feebly denticulated margins form a hooked beak (from which the turtle derives its name). The fore and hind flippers are well covered with small shields and are provided with two claws. The tail is very short. The body is long, narrow, and somewhat oval.

Geographic Distribution. - The home range of this species seems to be centered about the West Indies, extending north to Florida and the Gulf of Mexico, and south to Guiana and Brazil.

New England Records. - Until within a few years this turtle had not been recorded north of North Carolina. In 1909, however, Dr. F. B. Sumner (1909, p. 985) reported it from the region of Buzzards Bay, Mass. He says: "The fact does not seem to have been hitherto recorded that the 'hawk-bill' or tortoise-shell turtle (Eretmochelys imbricata) not infrequently reaches the coast of southern New England. Its occurrence has not been mentioned in any list of the reptiles of Massachusetts, and I have found no reference to its having been observed

${ }^{1}$ Carettochelys insculpta, the single species of an entirely different family and the superfamily Pleurodira, or sidenecked turtles, which resemble the sea turtles in having paddle-shaped extremities, is only eighteen inches in length (carapace). This turtle is recorded from Fly River, New Guinea. 
north of North Carolina. Small specimens of both the Loggerhead and hawk-bill are, however, occasionally taken in local fish traps, and one or two of the latter have been preserved in the museum of the laboratory. A specimen ten or twelve inches long was taken among floating sargassum by Mr. Édwards in August, 1908, and was kept for some time in the shark pool of the station. ${ }^{1}$ I learn from Mr. Edwards that individuals as large as eighteen inches long are not infrequently captured. This species is readily distinguished from the loggerhead (Caretta caretta) by the presence of four costal shields, instead of five as in the latter, and from the green turtle (Chelonia mydas) by the presence of two prefrontal plates on each side of the head." It is now, therefore, included in the fauna of the "waters of Woods Hole and Vicinity" (Sumner, Osburn and Cole, 1913, pt. 2, p. 774).

There is a small specimen under six inches in length from the vicinity of Woods Hole in the Biological Laboratory Museum. It is reported to be more common in Buzzards Bay than the Loggerhead.

Individual Range.- Probably not as great as that of the larger sea turtles.

Numbers.-Formerly common within its home range, this species has been so persistently hunted that it is surely being exterminated. Large specimens are rarely taken today.

Breeding.- Similar to, although more cautious than some of the other sea turtles, they approach the sandy shores of tropical and semitropical islands to deposit their eggs in May or June (West Indies). The eggs are not perfectly spherical, but more or less irregular. These turtles are believed to return again and again to the same spot for laying. In 1626 a Hawksbill Turtle was taken from Hambangtotte which bore a ring attached to one of its flippers that had been placed there by a Dutch officer thirty year's before, with a view to establishing the fact of the recurrence of visits to the same beach.

Habits.- While sea turtles of this family are shy and inoffensive, defending themselves with their flippers rather than by biting, this species seems to be more pugnacious than the others. It has been known to attack the Green Turtle (in confinement). It has been taken among floating sargassum and has been found in Long Island Sound as late as the Thanksgiving season (late November) exhausted by the cold. Its favorite haunts are the clear tropical seas with their abundance of marine life.

Food.- These turtles are considered chiefly carnivorous. In confinement, at least, they are "voraciously fond of cut-up fish, taking the food from one's fingers" (Ditmars, 1910, p. 49). Their heavy beaks enable them to break the shells of mollusks and crustaceans which also form part of their diet.

Enemies.-Again in this species man is the chief enemy. A certain number of animals are taken with hook, net, spear, or trap. Audubon, ${ }^{2}$ who visited the Tortugas Islands on the

${ }^{1}$ This specimen was to have been presented to the Boston Society of Natural History, but in some way escaped. - H. L. B.

${ }^{2}$ Audubon, J. J. Ornithological Biography, 1835, vol. 2, p. 375. 
Marion, gives the following account of one method of capturing these turtles: "An iron instrument, which he called a peg [is used], and which at each end had a point not unlike what nail-makers call a brad, it being four-cornered but flattish, and of a shape somewhat resembling the beak of an Ivory-billed Woodpecker, together with a neck and shoulder. Between the two shoulders of this instrument a fine tough line, fifty or more fathoms in length, was fastened by one end being passed through a hole in the centre of the peg, and the line itself was carefully coiled and placed in a convenient part of the canoe. One extremity of this peg enters a sheath of iron that loosely attaches it to a long wooden spear, until a turtle has been pierced through the shell by the other extremity. He of the canoe paddles away as silently as possible whenever he spies a turtle basking on the water, until he gets within a distance of ten or twelve yards, when he throws the spear so as to hit the animal about the place which an entomologist would choose, were it a large insect, for pinning it to a piece of cork. As soon as the turtle is struck, the wooden handle separates from the peg, in consequence of the looseness of its attachment." Later the exhansted turtle is drawn in by hauling on the line. The great majority, however, are captured when they approach the beaches to deposit their eggs. Oftentimes the turtles are killed before laying, a custom which does not tend toward the preservation of the race. The young turtles and eggs are exposed to danger from predaceous fish, birds, and mammals, as in other species.

Economic Importance.- This turtle furnishes the "tortoise shell" of commerce, hence its high economic value. The thirteen neural and costal shields are used, the marginals being of inferior quality. The shields take a very high polish. Formerly the process of removing the shields was a very cruel one, involving a living turtle. Tennent (1861, p. 293) thus describes it: "If taken from the animal after death and decomposition, the colour of the shell becomes clouded and milky, and hence the cruel expedient is resorted to of seizing the turtles as they repair to the shore to deposit their eggs, and suspending them over fires till heat makes the plates on the dorsal shields start from the bone of the carapace, after which the creature is permitted to escape to the water. . . A At Celebes, whence the finest tortoise-shell is exported to China, the natives kill the turtle by blows on the head, and immerse the shell in boiling water to detach the plates. Dry heat is only resorted to by the unskilful, who frequently destroy the tortoise-shell in the operation." The method described by Tennent was resorted to in the belief that a new set of shields would be produced. As a matter of fact, however, new shields are formed only if the Malpighian layer ${ }^{1}$ of the skin has not been destroyed by the heat; and these new shields are very thin, brittle, and of no commercial value. Presentday methods of removing the shields are more humane: the turtle is first killed, then

${ }^{1}$ The Malpighian layer is vital to regeneration of the more superficial structures. When this layer is destroyed the entire affected area becomes necrotic and sloughs off. New tissue then forms through the multiplication of Malpighian cells from the surrounding healthy portions. In turtles this is a very slow process. 
immersed in boiling water until the shields loosen, or buried in the sand for about a week, when the shields can be easily detached. Large specimens yield as much as eight or ten pounds of "shell." "Tortoise-shell is worked precisely as horn; but owing to the high value of the material, care is taken to prevent any waste in its working. The plates, as separated by heat from the bony skeleton, are keeled, curved, and irregular in form. They are first flattened by heat and pressure, and superficial inequalities are rasped away. Being harder and more brittle than horn, tortoise-shell requires careful treatment in molding it into any form, and as high heat tends to darken and obscure the material, it is treated at as low a heat as practicable. For many purposes it is necessary to increase the thickness or to add to the superficial size of tortoise-shell, and this is readily done by careful cleaning and rasping of the surfaces to be united, softening the plates in boiling water, or sometimes by dry heat, and then pressing them tightly together by means of heated pincers or a vise. The heat softens and liquefies a superficial film of the horny material, and that with the pressure effeets a perfect union of the surfaces brought together. Heat and pressure are also employed to mold the substance into boxes and the numerous artificial forms into which it is made up.

"Tortoise-shell has been a prized ornamental material from very early times. It was one of the highly esteemed treasures of the far East brought to ancient Rome by way of Egypt, and it was eagerly sought by wealthy Romans as a veneer for their rich furniture. In modern times it is most characteristically used in the elaborate inlaying of cabinet work known as buhl furniture. It is also employed as a veneer for small boxes and frames. It is cut into combs, molded into snuff-boxes and other small boxes, formed into knife-handles, and worked up into many other similar minor articles. The plates from certain other tortoises, known commercially as turtle-shell, possess a certain industrial value, but they are either opaque or soft and leathery, and cannot be mistaken for tortoise-shell. A close imitation of tortoiseshell can be made by staining translucent horn." I

In 1909, 2,040 kilograms of tortoise-shell were exported from the Philippines. The finest quality "shell" is said to come from the Eastern Archipelago, but large quantities are obtained in the West Indies and off the coast of Brazil.

In spite of Audubon's assertion that it is good, the flesh of this turtle is not generally used for food. 
Curetta caretta (Linné).

LOGgerheAd TURTLE.

Plate 18, Figs. 3, 4.

Testudo caretta Linné, Syvst. Nat., ed. 10, 1758, vol. 1, p. 197.

Caretta caretta Stejneger, Ann. Rept. U. S. Nat. Mus. for 1902, 1904, p. 715.

The Loggerhead Turtle is at once conspicuous by its relatively large head.

Size.- These turtles not uncommonly reach three and one-half feet in length of carapace and weigh over three hundred pounds. Very large specimens having a carapace four feet long and weighing nearly five hundred pounds have been reported.

Color.- The general color is brownish or black above and a pale yellow beneath.

Description.- As above stated the head is very large and covered with small shields. There are normally five pairs of costal shields instead of four as in other Cheloniidae and in the adult the carapace, which is highly arched and heavy, is completely ossified. There are twenty-seven marginals. The front flippers are covered with plates and usually (always in young) possess two nails. The anatomical variations in this species, especially in the number of horny shields of the carapace, is great. From the normal number, sixteen (six neurals and five pairs of costals), they increase to twenty-four, with various intermediate combinations. These shields vary greatly in size, pattern, and color. Young specimens have three distinct keels above and the shields of the carapace are slightly imbricated.

Geographic Distribution.- The Loggerhead Turtle has a somewhat wider range than the Green or the Hawksbill Turtles. Its home is in tropical and intertropical seas, from which it pccasionally wanders great distances. It is a frequent visitor along our North Atlantic coast and is well known in the Mediterranean and on the western coast of Europe and the British Isles. There is a record of a turtle of this species land-locked in Loch Lomond. ${ }^{1}$

New England Records.- Travelling northward in the Gulf Stream, Loggerhead Turtles not uncommonly visit Long Island Sound and the Massachusetts coast. Sumner, Osburn, and Cole (1913, pt. 2, p. 774) report it from the vicinity of Woods Hole. They say: "Menemsha Bight in traps; a number of specimens usually about two feet in length taken every year." They have been taken in Long Island Sound in a benumbed conclition as late as December 4. One came ashore "drowned in the surf" at East Saudwich, Mass., (1886). There are three specimens of this turtle in the Museum of the Boston Society of Natural His-

${ }^{1}$ Notes Leyden Mus., 1895, rol. 16, p. 211 (quoted by Gadow, 1901). 
tory: two from the vicinity of Woods Hole and one from No Man's Land, Mass. Two of these are quite young.

Numbers. - This is the commonest as well as the largest of the Cheloniidae. The region throughout the West Indies, north to the Gulf of Mexico, and south to Brazil, represents the area of greatest abundance.

Breeding.- The Loggerhead Turtle is, perhaps, most widely known in connection with its breeding habits. Owing to the fact that it comes farther north to make its nest than any of the other sea turtles, its eggs have been more available and hence most commonly used in embryological researches in this class of animals. ${ }^{1}$

The nests are found along the Atlantic coast from Florida northward through Georgia, South and North Carolina, even to Virginia. Coker (1906) from the Laboratory of the United States Bureau of Fisheries at Beaufort, North Carolina, has made the following interesting observations regarding its breeding habits: "The laying season, beginning the latter part of May, extends into August.

"The nests seem to be made at night, for the sign by which a nest is located is the fresh track found in the early morning leading from the edge of the water to the point where the eggs were laid. Not infrequently the course of the tracks shows that the turtle returned to the water without depositing eggs, and thus there may or may not be indications that a nest was started. Sometimes, in such cases, another track will be found not far away leading to an actual nest.

"Early in the morning the nests are sought by a few fishermen who value the eggs to eat or to sell for that purpose at five cents per dozen. A sharp stick is carried with which to probe into suspected places. If the end of the probe, when withdrawn, is smeared with yolk, a nest has been located. Sometimes they are destroyed by hogs; and nests have been found with only fragments of shell and yolk strewn about. During the day the tracks are liable to be obliterated by tide and wind, and sometimes by rain, so that nests that are not found on the following day are usually safe from molestation, at least, by man.

"In 1905 eggs were taken on the following dates: June 14th (2 nests), 15th, 19th, 27th (2 nests), 29th, 30th, July 8 th (2 nests), 10th ( 2 nests and signs observed of 2 others destroyed by hogs), 22nd (2 nests), and 2Sth. On May 31st, I was reliably informed of nests found during the preceding week, May 21-27, and, later, of a nest dug about June 5 th; but collecting trips on the 6 th and 10th were fruitless. In 1903 nests were reported a few days before and after June 14th, and I dug one on July 9th. In 1904 nests were reported July 24th and on August 5th eggs were brought by a fisherman, who reported the finding of four nests, two of which had been destroyed by hogs. The laying season near Beaufort probably begins in May and may extend into August, but is chiefly June and July.

"Agassiz's "Comparison of the growth of the Chelonii with that of the Amydae" is based on the embryology of this species and Chrysemys picta. 
"In 7 nests the following number of eggs were counted respectively: 118, 123, 128, 143, $136,152 .^{1}$ Various other numbers were reported by a fisherman who brought eggs to the laboratory. In one case he brought 42 eggs, and reported 60 as the number found in the nest.

"Form of nests. - The top eggs were about 13 inches below the surface $\left(12,12,12 \frac{1}{2}, 13,13\right.$, and 15 inches being the actual measurements in 6 nests). The mass of eggs, being from 8 to 12 or more inches deep, the lowest eggs were from 20 to 26 inches below the surface. In one instance the eggs were removed without destroying the shape of the hole. The space occupied by the eggs was sub-spherical with flat top, and was 10 inches in diameter by 8 inches deep. This nest contained only 123 eggs.

"The changes of temperature at such a depth during the course of a day were not followed, but, when the nests were taken - time of day varying from 6 to $11 \mathrm{~A}$. M.- the temperatures noted showed little difference, varying from $26 \frac{1}{2}$ to 28 degrees centigrade. Sand taken from the side of one nest was found to contain 3.8 percent of water.

"Location of nests. - In the cases of about eight nests observed by the writer, and in every other case, so far as known, the nests were located either just below or just on the foot of the slopes of the steep sand-dunes that line the beach on Bogue Banks. Hence the distance of nests from the water varied considerably. The elevation of the nests above the water level also varied considerably. Without means of making accurate observations from a fixed bench-mark, a spirit level and vertical rod were used to measure the approximate elevations of these nests. For three elevations taken the same day, a distinct line on the beach made by a recent very high tide was used as a base. The elevation of the surface of the ground at the nest, above the base line, was found to be in one case 4.75 feet, in a second, 5.7 feet, and in a third, 6.3 feet. The lowest eggs in these nests would thus be from 2.75 to 4.3 feet, roughly, above the level of a very high tide. The surface of the ground at another nest was washed by a very high tide, while I was present; yet the eggs from this nest, marked and left, hatched very successfully. The base of the sand-dunes, and not the distance above water, seemed to be the chief factor in determining the location of the nest. Almost all of the nests were made, however, in regions where this location would be not very distant from the edge of the water.

"The nests were found along the beach from the region of Hoop Hole Camp ( 5 miles west of Fort Macon) to about four miles west of the 'Old Steamer' (a local landmark formed by a wreck situated about 10 miles west of Fort Macon). The search was not continued farther west.

"Thus, the conditions at the various nests were rather uniform as regards:

Location at foot of dunes.

Depth and form of nest.

Time of laying, in so far as all nests were probably made at night.

${ }^{1}$ Gadow $(1901$, p. 387 ) cites a specimen captured on the Dutch coast in 1894 that contained 1150 eggs. 
"They were variable, however, in respect to:

Elevation above water-level.

Distance from water-line on beach.

Number of eggs laid.

Date of laying (May to August)."

Another observer (Coles, 1914) states that the laying of each egg at intervals of from ten to fifteen seconds is accompanied by a convulsive movement; that the turtle appears not to notice the presence of an intruder while laying and that on one occasion he received about thirty of the eggs in his hand as they were laid. He also states that the turtle later showed a disposition to defend her nest.

Mast (1911) has described the behavior of the Loggerhead Turtle in depositing its eggs, as follows: "The loggerhead turtle ordinarily comes out of the sea in the early part of the night and lays its eggs in the sand on the beach above high-tide water-mark. On July 11, 1910, I was fortunate enough to be present when a turtle came out to lay on Loggerhead Key, Florida, while it was still daylight $\left(7^{\mathrm{h}} 5^{\mathrm{m}}\right.$ P. MI.). This individual was about 3 feet long and 2 feet wide. She came out at right angles to the water line and proceeded directly up the beach 50 to 60 feet, where she immediately began to make her nest. There was no indication whatever of a process of selection of the place for the nest, as some have asserted in describing the breeding habits of this turtle. When the turtle reached the nesting-place she stopped and began at once to move the posterior end from side to side, throwing the sand out sidewise and forward alternately, with the two hind flippers, to a distance of 5 to 6 feet. Thus a crescentshaped trench was made, wide and deep in the middle and narrow and shallow at either end. This trench was over 4 feet long and nearly 10 inches deep in the middle. The lateral movement of the turtle during this process of digging was largely due to the action of the nuscles connected with the front flippers, which remained stationary as the body turned on them.

"After the trench was finished the turtle took a position so that the right hind leg was very nearly over the middle of the bottom of it. This flipper was then thrust vertically down into the sand (the flat surface being nearly parallel with the long axis of the body) and the end turned in under the sand so as to form a cup much like one formed by a human hand partly closed. The posterior end of the animal was then raised by the action of the left leg and pushed to the right. During this process the right flipper, containing a fair-sized handful of sand, was of course raised and as the posterior end of the body moved to the right the flipper gradually rotated so as to face backward; it was then thrust out to the side and inverted so as to empty the sand in a heap, just in front of which the foot was placed on the ground in the customary position. The left flipper was now directly over the hole made by the right one and used in removing sand just as described, except that it took the sand from the right side of 
the hole while the right flipper took it from the left side. Before the body was pushed back to the left by the right leg it made a sudden movement forward and threw out a considerable bit of sand, making a hole just in front of the place where the sand taken from the nest had been deposited. This sand was pushed into the hole in front of it when the turtle moved back to the right again and thrown out just before it moved to the left the following time. Thus the two hind flippers alternated in scooping the sand from the nest until a cylindrical hole was dug nearly as deep as their length. The alternation from right to left was perfectly regular. Neither flipper ever took sand from the hole twice in succession.

"After the hole was completed the turtle assumed a position so that the cloaca was very nearly over the center of it and began to lay at once. The cloaca projected fully 2 inches during the process of laying. The head was well extended and flat on the ground. The anterior end of the body was raised so that the ventral surface made an angle of about $20^{\circ}$ with the horizontal. There was no arrangement of the eggs in the nest as fishermen sometimes assert. The eggs were dropped from the cloaca into the hole in a series of one or two at a time at intervals of from 4 to 8 seconds. Two were deposited together about every fourth time. During the discharge of the eggs the hind flippers were slightly raised, and in one case (witnessed at night earlier in the summer) there was heavy breathing which was very distinctly heard. In the turtle under present consideration, however, not the slightest sound was detected.

"Fishermen often say that after a turtle begins to lay it will continue even if it is turned on its back. I did not try this, but I did strike the turtle a sound blow on the head with a heavy stick, using both hands, at two different times while she was laying. She withdrew her head, moved slightly to one side and stopped laying, but only for a few moments. Noise and gentle contact did not appear to affect her in the least.

"It is commonly thought that the loggerhead turtle ordinarily lays three times during each summer, about 150 eggs the first time, fewer the second time, and about 80 the third. I did not ascertain precisely how many eggs were laid by the turtle under observation. It is almost impossible to remove the eggs from the nest without killing the embryos, and, since there have been many trustworthy observations on the number of eggs laid, it seemed unnecessary to destroy the young for the sake of learning the exact number in this particular nest.

"Immediately after the eggs were discharged the turtle began to cover them. In doing this she moved the posterior end back and forth much as she did in digging the hole. As this end proceeded to the right the left flipper was thrust backward into the sand and then suddenly moved inward so as to throw and scrape the sand on to the eggs immediately back of it. As it proceeded to the left the right flipper acted in the same way, but of course it threw the sand in the opposite direction. Thus the turtle filled the trench as well as the hole, stopping frequently to pack the sand, especially that over the eggs. This she did by placing the posterior pointed end of the body on the sand and elevating the anterior end so as to bring her 
full weight to bear upon it. After the trench was nearly filled she turned about over the region several times and threw and scattered the sand in every direction with all four flippers so as to conceal the place, especially that where the eggs were laid. This completed she returned to the sea and entered only a few feet from the spot where she came out. On the way down the beach I stood on her back and she carried me (165 lbs.) apparently with but little effort. From what has been said regarding the concealment of the nest of the loggerhead turtle it must not be assumed that the nesting-place is difficult to find - quite the contrary, for the turtle-tracks leading to and from it are very conspicuous and can not be mistaken. The place where the eggs are buried is, however, not easy to find. In case of the nest described I had considerable difficulty in finding the eggs, even after carefully watching the whole process of laying and noting the position of the turtle in detail; and this is quite in harmony with the experience related to me by several fishermen who collect the eggs for food.

"The eggs in this nest were 11 inches below the surface, and they occupied a space 6.5 inches in depth and 9 inches in diameter, making the bottom of the nest 17.5 inches from the surface. The turtle under observation was out of water 42 minutes, approximately, 3 of which were required to come from the water to the nest, 4 to make the trench, 8 to dig the hole, 12 to lay the eggs, and 15 to fill the hole and trench, smooth off the place and get back to the sea. The rate of locomotion on land is about half a mile an hour."

The eggs are roughly spherical. The shells are calcareous, but soft. As incubation progresses the shells may become very distended. The incubation period in the natural state is about two months, but if the eggs are transferred, it nay cover nearly three months.

The young when hatched measure two and one-half inches and remain in warm shallow inlets while in a small and defenseless state. They seek the water instinctively as soon as hatched.

From a study of certain reactions to color in the young Loggerhead Turtle, Hooker (1911) draws the following conclusions:

"(1) The newly-hatched loggerhead turtle moves away from transparent and opaque red, orange, and green, and from green bay-cedar bushes, and moves toward transparent or opaque blue.

"(2) After entering the water, the animal swims out to sea, apparently attracted by the darker blue of the deeper water. The position of the sun is an entirely negligible quantity.

"(3) When on the beach in a large sand-pit with level floor, from which pit sight of the bushes and the ocean is excluded, but into which the sun's rays shine directly, there is exhilbited no definite tendency to move in any definite direction.

"(4) Young loggerhead turtles are negatively geotropic, but when all possible downward inclines have been exhausted they become positively geotropic.

"(5) Under a restricted environment the young turtle is photophilous and responds to 
a large surface of light of low intensity rather than to an illuminated point of high intensity.

"(6) The reactions of the young turtle are not modified by sound or odor of the sea, nor by a tank of sea-water in which there is not sufficient quantity to give color.

"It might be well to state here that the colors used, both glass and paints, were far from monochromatic, so that their exact values are not known, but at the same time it should be remembered that most or all of the colors in nature are polychromatic. An excess of any particular color seems to give the effect. That we are dealing here with a case of true chromotropism is, perhaps, somewhat doubtful. Indeed, true chromotropism is so rarely met with and so many other factors, as intensity, the "color-blindness" of lower eyes, etc., contribute to it or to startlingly similar reactions, that I have studiously avoided the term. I must also confess myself unable to satisfactorily explain the cause of the response obtained at night on the beach. While the moon shone brightly the differences in colors were much reduced to the human eye, so much so that, as far as color was concerned, the bushes and the water were practically the same. However, the sea was shiny and the bushes were not. This reaction seems to me to be, as I have before stated, a transitional stage between the color reaction and the photophilous response, but this helps us little in explanation of its ultimate factors.

"In regard to the responses in the daytime, we may speak with a little more certainty, although here, too, the intensity of the colors is a bothering element. Practically all tlie investigators who have worked on color responses have found that blue or the blue end of the spectrum acts as white light and the red end of the spectrum as shadows would in phototropic responses. In the case of these loggerhead turtles we find blue chosen in preference to the directive rays of the sun. Whether this indicates a true chromotropism or not we can not be entirely sure.

"The application of the bare facts obtained to their biological significance in the life of the animal, is, I think, clear. Bushes, green in color, grow on all islands of any size, above the high-water mark. The shores of all islands slope down to the water. All turtles' nests are laid just above the high-tide mark, at or near the bush line. The young turtle, hatching out and crawling up to the surface of the sand, aroids the bushes, goes down the shore, and easily finds the water. Once in, the darker blue of the deeper water attracts it out of the dangerous fish-infested shoals of the reefs."

Habits. - The Loggerhead Turtle is a strong swimmer and has been taken in mid-ocean, apparently asleep on the surface of the water. It also enters the mouths of rivers, sometimes travelling several miles upstream. Adult specimens are often caught which are covered with barnacles, even inside the mouth. Ditmars (1910, p. 45) thus describes its actions when on shore: "To discover one of these sea monsters on the beach is to experience a certain feeling of awe. The great, floundering brute, in the fulfillment of parental duties, is practically at 
man's mercy, yet clumsily alert. It suddenly exhales the breath with a decp, roaring sound, while the bleary, seal-like eyes stare in a secmingly vacant fashion. If a big conch shell is shoved within reach of the jaws, it is seized and crushed in a single grasp. Turned on its back, the giant is helpless. If not hindered, it makes for the sea, causing a great commotion in reaching the water, as it flounders for sufficient depth where it may find purchase for the paddlelike limbs." In swimming it carries its front flippers well up over the back, in a manner suggestive of the mings of a bird.

Food.-- This turtle is consiclered chiefly carnivorous in its natural state. It has been known to eat blue crabs (Mellita), shellfish such as "the various Buccinii and Trochi, especially a large conch (Strombus) which it breaks easily between its stout mandibles" (Holbrook, 1842, vol. 2, p. 37). Fowler (1914) found the stomach contents of one to consist entirely of the remains of the hermit crab (Pagurus pollicaris) and borers (Natica duplicata).

Enemies. - The greatest depletion in numbers comes cluring early growth, while the young turtles remain in shallow waters. There they become victims to predaceous fish, birds, and mammals. The eggs are sporadically hunted by natives and fishermen. Raccoons and hogs have also been known to destroy the nests. The adult turtles are not persistently hunted by man.

Economic Importance.- This turtle has a far less commercial value than either the Green or the Hawksbill Turtles, although it is brought to American markets in considerable numbers to be sold for food. The flesh is dark colored and coarser than that of the Green Turtle, and resembles beef in color and flavor. In this connection Hornaday (1914, vol. 4, p. 48) relates the following incident: "The flesh of this animal bears so close a resemblance to beefsteak that even a butcher can not always detect the difference. One Christmas morning, at Key West, I dissected a large Loggerhead. The flesh was fresh, and very tempting, and when a choice lot of steaks were offered to the landlady of a certain small hotel, they were gratefully accepted.

"It happened that the butcher" who supplied the hotel with beef and mutton was a boarder thereat; and as became his calling, he sat at the head of the long table, and served the meat. Although he was an able butcher, he had one weakness; and it lay in the fact that he 'could not eat turtle-meat'; it was 'too oily,' 'too musty,' and too far removed from beefsteak.

"With no unnecessary announcements, the turtle-steaks were fried, $\grave{a}$ la bcefsteak, and set before the butcher. He served them as beefsteak, ate his own portion with evident relish, and all the other guests ate theirs. The butcher had nearly finished his second instalment, without having discovered the substitution, when he was asked how he liked turtle-steaks for a change."

Near its breeding grounds, the eggs are sometimes sold locally to be used for food. 


\section{Family CHELYDRIDE. \\ Chelydra serpentina (LinNé). \\ Snapping Turtle; Snake Tortoise; Torup.}

Plate 20.

Testudo serpentina Linné, Syst. Nat., ed. 10, 1758, vol. 1, p. 199.

Chelydra serpentina Schweigger, Arch. Naturw. Math., Königsberg, 1812, vol. 1, pt. 3, p. 293.

The Snapping Turtle is the largest of our New England fresh-water Chelonians.

Size.- Large individuals attain a total length of about three feet. Of this the carapace will average only slightly over one-third owing to the very long neck and tail. Such a turtle will weigh about fifty pounds. These large specimens, however, are not common. Measurements of the shell of a male specimen in my collection are: length of carapace, 12 inches; width of carapace, $9 \frac{1}{4}$ inches; length of plastron, $4 \frac{1}{2}$ inches; width of bridge, 2 inches, tapering to $\frac{3}{4}$ of an inch at center. A mounted specimen in the collection of the Boston Society of Natural History with a carapace length of $14 \frac{1}{4}$ inches, shows a width of head of $3 \frac{1}{2}$ inches.

Color. - The carapace and upper parts vary from light to dark brown, sometimes black. The carapace is often covered with an algal growth, which gives it a distinctly greenish tint. The plastron and under parts are pale yellow.

Description.- The head is very large and pointed. The upper and lower jaws terminate in strong hooked beaks. Owing to the low arch of the skull the eyes are placed at such an angle that the range of vision extends upward as well as to the side. The neck, which is covered with loose, warty skin, is of such length that the head can not be completely withdrawn into the shell. The carapace has three blunt, irregular keels, very pronounced in young individuals, but which gradually disappear with age, until in very old specimens the shell is quite smooth. ${ }^{1}$ It is sharply serrated posteriorly. The plastron is small and cruciform in shape, thus leaving the under fleshy parts exposed. The tail is long and has on its superior surface a series of blunt horny crests. There are also two smaller lateral rows. The under surface of the tail is covered with large shields. The feet are broad and webbed, the toes being provided with large coarse nails, five anteriorly and four posteriorly. ${ }^{2}$

Geographic Distribution. - This turtle has the widest range of any fresh-water Chelonian under consideration. It extends from southern Canada, through the United States east of the Rocky Mountains, into Central America.

${ }^{1} \mathrm{H}$. W. Fowler (1913) describes three large ones in the Philadelphia Aquarium in which the three keels on the carapace were very prominent and did not get smoother.

${ }^{2} \mathrm{H}$. Garman (1892), speaks of a pair "attached side by side for most of their lengths," a peculiar malformation. 
New England Records. - It has been reported from every New England State and is considered common throughout most of the region. In the collection of the Boston Society of Natural History, there are five specimens: one from Wellesley, one from Gloucester (juv.), one from Riverview, Charles River, Mass., and two from the vicinity of Augusta, Maine.

Breeding Habits.- Agassiz (1857, vol. 2, p. 496) found that in New England the Snapping Turtle always laid its eggs between June 10th and 25th. I have never found it laying outside of these time limits. During this season the female is commonly seen travelling about, often at a considerable distance (one-eighth of a mile or more) from any body of water. The nests are often made in the side of a bank and in scooping out the earth with her hind legs, the turtle often loosens it above so that she is partially or almost completely buried while laying. Upon crawling out, this earth falls over the eggs and covers them. The following is an amusing account of the actions of a female in selecting a nest site as observed by the late Professor J. W. P. Jenks, and related by Dallas Lore Sharp (Face of the Fields, 1911, p. 40):

"Leaving my horse unhitched, as if he, too, understood, I slipped eagerly into my covert for a look at the pond. As I did so, a large pickerel ploughed a furrow out through the spatterdocks, and in his wake rose the head of an enormous turtle. Swinging slowly around, the creature headed straight for the shore, and without a pause scrambled out on the sand.

"She was about the size of a big scoop-shovel; but that was not what excited me, so much as her manner, and the gait at which she moved; for there was method in it and fixed purpose. On she came, shuffling over the sand toward the higher open fields, with a hurried, determined seesaw that was taking her somewhere in particular, and that was bound to get her there on time.

"I held my breath. Had she been a dinosaurian making Mesozoic footprints, I could not have been more fearful. For footprints on the Mesozoic mud, or on the sands of time, were as nothing to me when compared with fresh turtle eggs on the sands of this pond.

"But over the strip of sand, without a stop, she paddled, and up a narrow cow-path into the high grass along a fence. Then up the narrow cow-path on all fours, just like another turtle, I paddled, and into the high, wet grass along the fence.

"I kept well within the sound of her, for she moved recklessly, leaving a trail of flattened grass a foot and a half wide. I wanted to stand up,- and I don't believe I could have turned her back with a rail, - but I was afraid if she saw me that she might return indefinitely to the pond; so on I went, flat to the ground, squeezing through the lower rails of the fence, as if the field beyond were a melon-patch. It was nothing of the kind, only a wild, uncomfortable pasture, full of dewberry vines, and very discouraging. They were excessively wet vines and briery. I pulled my coat-sleeves as far over my fists as I could get them, and with the tin pail of sand swinging from between my teeth to avoid noise, I stumped fiercely, but silently on after the turtle. 
"She was laying her course, I thought, straight down the length of this dreadful pasture, when, not far from the fence, she suddenly hove to, warped herself short about, and came back, barely clearing me, at a clip that was thrilling. I warped about, too, and in her wake bore down across the corner of the pasture, across the powdery public road, and on to a fence along a field of young corn.

"I was somewhat wet by this time, but not so wet as I had beeu before wallowing through the deep, dry dust of the road. Hurrying up behind a large tree by the fence, I peered down the corn-rows and saw the turtle stop, and begin to paw about in the loose soft soil. She was going to lay.

"I held on to the tree and watched, as she tried this place, and that place, and the other place - the eternally feminine. But the place, evidently, was hard to find. What could a female turtle do with a whole field of possible nests to choose from? Then at last she found it, and whirling about, she backed quickly at it, and, tail first, began to bury herself before my staring eyes."

Agassiz also recorded the fact that the Snapping Turtle always lays its eggs (in this region) in the morning from four till twelve mid-day. My observations have coincided with this statement. The nests are sometimes made in unexpected locations. Several years ago, one June morning (June 19) I came upon a female Snapper in the middle of a sandy, country road, in the act of depositing her eggs. She seemed wholly unconscious of the presence of intruders, even when my dog approached and sniffed at her. On being removed from the nest, however, her attitude immediately changed to uncontrollable viciousness, snapping with a force that brought the whole body into play. The nest was about $5_{2}^{\frac{1}{2}}$ inches deep, expanded at the bottom and to one side, and contained twenty-eight roughly spherical eggs. These averaged seven-eighths of an inch in diameter. The shell was thin, fairly tough, but pliable. The eggs were in one group, not separated by layers of earth.

Habits.- These turtles inhabit stagnant pools and sluggish streams. They are almost entirely aquatic. When in need of oxygen they approach the surface and float about with only the nostrils visible. They are not confined to fresh-irater streams and marshes, for I have taken several individuals in salt marshes on Cape Cod and recently received a young animal which was taken while swimming in Buzzards Bay. The carapace of this turtle was distinctly green in color. Much of their time is spent partially submerged in mud, on the bottom of the pond or stream, in which position, especially when the carapace is coated with green algae, they so resemble their environment that the capture of small fish and other aquatic forms is accomplished readily by a lightning thrust of their head. Because of the strength of jaw muscles, sharpness of mandibles, and rapidity of head motion, these animals, especially adults, are dangerous to handle, being capable of inflictiug severe wounds, but they can be safely carried by the tail. The following description of its vicious behavior is from an old 
narrative written by an English explorer: " "The Heats were now grown so excessive, that our Provisions would be spoil'd in twenty four Hours. This put us upon Hunting the Tortoise; but 'twas with much difficulty that we could take any; for being very quick of hearing, they would throw themselves into the water upon the least noise. However, we took one at last, which was much larger than any we had seen. . . . Whilst I was contriving to cut off his Head, he had like to have been before-hand with me, by snapping of my Finger with his teeth, which are very sharp." On land the gait of these turtles is slow and leisurely. Their trail over the sand is very characteristic, consisting of a continuous, undulating, central line, produced by dragging the tail, and bordered on each side by series of shorter parallel curved lines produced by dragging the toes. The trail of an adult is eight or more inches wide. Snapping Turtles thrive in captivity, although always retaining their sullen dispositions. My young captive specimens often completely buried themselves in the sand.

Food Habits. - This species is chiefly carnivorous, its diet consisting of fish, small reptiles and mammals, amphibians, and other aquatic animal life. It is also destructive to young water-fowl, which are seized and pulled under water, to be eaten at leisure. Storer (1840) states that "farmers sometimes complain of its depredations among their chickens and ducklings." Ditmars (1910, p. 9) describes its habit of prowling "along the edge of a pond or stream in search of frogs, which, in turn are squatting, snout toward the bank, on the watch for insect prey." That the diet is not wholly carnivorous is shown by the stomach contents of an adult healthy male which I took in a salt marsh in Sagamore, Mass., July 9, 1916 (Babcock, 1916). This stomach was well filled with recently swallowed marsh-grass (Distichlis spicata) the blades being intact, but bent and tangled. Surface found in the stomach contents of nineteen animals of this species: algae, leaves, seeds, grass, slugs, snails, crayfish, insects, bugs, flies, beetles, portions of fish, frogs, snakes, birds, mice, and rabbits.

In spite of a voracious appetite the turtle will live for months without food. Shufeldt (1897) speaks of a young Snapper which went without food for three months, at the end of which period it ate some young snails and died on the third day following. This species is apparently unable to swallow food unless the head is under water.

Enemies.-The Snapping Turtle is not hunted extensively by man, although since its bad reputation for destructiveness to valuable game fish and young water-fowl is becoming more generally known, measures are sometimes taken to exterminate it from certain "stocked" ponds. An otter has been observed to bring one up through the ice and eat off the head. Raccoons and skunks have been seen to destroy the nests. The eggs are sometimes collected (the nests being located by probing with pointed sticks) and sold for a small price, to be used as food. One of my specimens was infested by an intestinal parasite, a species of trematode.

Economic Importance. - The flesh of this turtle is used for food, large numbers of animals

${ }^{1}$ Hennepin, L. A New Discovery of a Vast Country in America. London, 1698, p. 188. 
being sold in the markets of our large cities. ${ }^{1} \quad$ There is a strong odor of musk, however, which detracts from its value, for it commands only a small price. Used in a soup the flavor is said to be excellent. It is captured mostly with a baited hook which it takes readily, often to the exasperation of fishermen. Formerly in country districts it was a common custom to keep a Snapping Turtle in the swill barrel, where in the course of time, it grew exceedingly fat, very tender, and lost most of its musky odor. It was then killed and eaten. Mr. S. W. Denton of Wellesley, Mass., tells me that he knew of a turtle kept under such conditions which reached the weight of eighty-six pounds.

The eggs are sometimes used as food. The oil from this turtle has been supposed to possess certain medicinal virtues when applied externally to sprains or bruises.

In view of its predaceous habits in destroying young game, fowl, and fish, and its limited value as food, the balance seems to be on the negative side as regards its economic value. In his Natural Enemies of Birds, Forbush (1916) says: "So far as I have been able to learn only one turtle, native to Massachusetts, can be counted as an enemy of birds. This is the snapping turtle (Chelydra serpentina). It has been known to kill and eat young night herons that had fallen from their nests, and is considered the greatest enemy of young waterfowl. It frequents muddy ponds, to which waterfowl resort, and drags them down by the feet. I have known one in this way to tear a leg from a living adult Canada goose, which escaped but afterward died. All who attempt to raise wild fowl in the natural way must first clear the breeding pond of this terrible enemy; else it will be difficult to rear young birds."

${ }^{1}$ R. C. Murphy (Copeia, 1916, no. 33, p. 58), speaks of a small tribe of American Indians (Poospatuck) on Long Island that uses the Snapping Turtle for food. 


\section{Family KINOSTERNIDAE. \\ Kinosternon odoratum (LATREILLE). \\ Musk Turtle; Stink-pot,}

Plate 21.

Testudo odorata Latreille, Hist. Nat. Reptiles, 1802, vol. 1, p. 122.

Kinosternon odoratum Gray, Syn. Reptiles, 1S31, p. 35.

The Musk Turtle, or Stink-pot, is the smallest of the New England Chelonians.

Dimensions. - The length of the carapace generally does not exceed five inches. The measurements in inches of a specimen in the collection of the Boston Society of Natural History are: length (in a straight line), $4 \frac{7}{8}$ inches; length along curve of carapace, $5 \frac{1}{2}$; width (in a straight line), $3 \frac{1}{4}$; width along curve of carapace, $4 \frac{3}{4}$; height, $1_{\frac{3}{4}}^{3}$; sternal length, 3 ; sternal width, 2 ; width of head, $1 \frac{3}{16}$.

Color.- The carapace varies from light to dark brown, with or without spots, and is often covered with green Confervae and numerous small leeches. The plastron is yellowish brown. The head and soft parts are a dull mottled black. There are two narrow yellow stripes on each side of the head, beginning at the nostrils and extending, one over and one under the eye, to the neck. In young animals, the shields sometimes have narrow black margins.

Description.- The body is long and narrow. The carapace in adults is smooth and highly arched. The plastron is small, narrow, and roughly cross-shaped, with lobes very feebly movable. The highest point of the carapace lies in the posterior half. The twenty-three marginal shields are only slightly serrated. The head is proportionately large. It is "long from the orbits of the eye backward, and short from thence, forward; it is pointed in front." The alveolar edges of both upper and lower jaws are sharp and well fitted for cutting. The neck is long and slender. The feet are short and the toes webbed. Internal characteristics are: the separation of the pubic and ischiadic symphyses, the presence of an ento-plastral plate, the possession of inframarginal shields, the widely open temporal fossae, and the rib-like pair of processes to the nuchal plate. The sexes are not alike. "The difference in the form of the shield consists in the greater width of its front part in the female. The tail of the male is much longer and stronger than that of the female. There is, in the male, a patch of rough scales in the bend between the thigh and the leg." In young specimens the carapace is strongly keeled. Young animals mature rapidly in form, attaining the shape of the adult during the first year. A pair of inguinal glands secretes a disagreeable and penetrating odor of musk from which it derives its name. 
Geographic Distribution.- This turtle has a wide range in the eastern part of the United States, extending from southern Canada to Florida, and westward to Missouri and Texas. It has been recorded from all of the New England States. In the collection of the Boston Society of Natural History are three specimens from the vicinity of Augusta, Maine; two from Ipswich, Massachusetts; and a shell from Dedham, Massachusetts.

Habitat.- These turtles inhabit ponds and slow running streams with muddy bottoms.

Numbers.- They are considered generally abundant throughout their range, but are not frequently observed owing to their strictly aquatic habits.

Breeding Habits. - In this region the female deposits her eggs in June - three, five, or sometimes seven, in number. They are elliptical (nearly twice as long as thick) with blunt ends and have a very smooth glazed surface. The shell is thick but brittle.

I have never observed one of this species in the act of laying. Agassiz (1857, vol. 2, p. 500) says he has seen it "laying but once, namely, at half-past eight in the evening." The following is an account of their egg-laying habits at Turkey Lake, Indiana: "The eggs are laid in the rotten rood in the tops of stumps standing in the margin of the lake. The turtles were frequently found in the tops of these stumps, and ome of their eggs wedged as far into the rotten wood as the finger could bore. Rotten logs removed some distance from the water are also favorable places for egg-laying, and in a mucky place of small area at the edge of the lake, 362 eggs were taken at one time.... While passing along a wheat field some turtles were seen coming from it, and on inspection it was found that they had deposited their eggs in the ground in depressions made by a cow while walking over the ground when it was soft. Still other eggs were found in bundles of rushes drifted together.

"An interesting change of habit seems to have taken place among these turtles during the past fifty years. Before that time the number of stumps standing in the margin of the lake must have been exceedingly small. The present large number is due to the rising of the lake after the building of the dam and the subsequent cutting down of the trees whose boles had become submerged. The habit of laying eggs in stumps cannot be of much more than fifty years' duration" (Eigenmann, 1896, p. 263).

The young when newly hatched, are one-half inch long (length of carapace, which is soft and pliable).

Habits. - This animal is strictly aquatic in its habits, seldom, if ever, leaving the water, except to deposit its eggs; hence, it is not commonly known. Its time is spent prowling about on the mudly bottom of ponds and streams in search of its food, or basking in the sun in shallow water. Its disposition is pugnacious and vicious, somewhat resembling that of the Snapping Turtle. It differs from the latter, however, in its method of snapping, for instead of quickly throwing out the head with a force that brings the whole body into play, it slowly stretches out its neck toward the object before snapping. The males are said to produce "stridulating 
sounds" by rubbing together the patches of horny tubercles which occur on the hind legs, but I have never observed it. Upon the approach of cold weather it burrows into the mud and hibernates until spring.

Agassiz (1857, vol. 1, p. 350) thus records his observations of certain movements of this turtle: "The manner of withdrawing the legs is very peculiar. The fore legs are carried round before the body; the elbow, somewhat raised, is carried directly back by the side of the head and neck into the scapular arch, the skin at the same time rolling off towards the feet and shoulders, and leaving its muscles as naked as those of the neck and scapular arch about it; the forearm is turned back, but not quite on to the humerus; the hand is either laid in against the head and neck, or turned back on to the humerus... The hind legs are withdrawn nearly horizontally, the knees like the elbows, though in a less degree, stripped of the skin; the foreleg is turned back upon the femur, and the foot again turned forward upon the foreleg. The tail is turned to one side. The head is drawn back to within the scapular arch, the skin rolling off from the neck, but not folding together before the head, as in the Emydoidae."

In confinement this turtle is very shy. Gadow (1901, p. 344) describes the actions of his captive specimens as follows: "It is mainly aquatic, and is one of the dullest and shyest species. My own specimens spend most of their time in the water, invariably in the darkest corners, preferably under a stone or a $\log$, and they do not leave their hiding places until dark, in search of worms, meat, and all sorts of animal food. For months I could never induce them to take food from a stick, or even to eat in my presence, and it was not until after many weeks that one of them at last protruded its head enough to exhibit the yellow stripes. When taken out of the water they draw in their heads, just allowing the vicious little eyes to be visible, and opening the sharp-edged mouth widely to bite deliberately and furiously at the unwary finger. Some spent the winter in the water, in the greenhouses, feeding as usual, others crept on land, hiding under moss, half buried in the soil, where they slept for several months, but with interruptions in order to soak and to drink. When spring is well advanced they prefer the water for their regular sojourn. Some which had been sent over from New York arrived in a deplorably dried-up condition, the skin being quite flabby and shrivelled, but after a few hours' soaking they came round, and increased considerably in weight, the limbs and neck becoming turgid."

Ditmars (1907, p. 21) has demonstrated its ability to lead a strictly aquatic existence. "Its movements when crawling about the bottom of an aquarium or in swimming show deliberation and perfect ease and prove the creature's fitness for exploring the muddy beds of rivers. As an experiment the writer kept several specimens in a deep aquarium, without means of leaving the water, or obtaining a foothold at the top, to breathe. The test continued for several weeks. These turtles either crawled about the bottom of the tank or swam leisurely to the surface for a breath of air. They fed readily and from all indications would have lived 
indefinitely under such conditions. Pond turtles or river turtles - terrapin - if thus treated, would have soon become exhausted and ultimately succumbed by drowning."

Food Habits. - The Musk Turtle is principally carnivorous, feeding on small fish, aquatic insects, worms, fish eggs, pollywogs, and other small forms of animal life. It often takes the worm-baited hook of fishermen. Surface found in the stomachs of four Musk Turtles: snails, insects, crickets, larvae of Lepidoptera, and beetles.

My young captive specimens were always voracious, taking flies, grass-crickets and other insects, although never attempting to attack the goldfish in the aquarium. They were especially aroused to action by earthworms, which they would attack with great vigor, hanging on while being thrown all about the tank by the contortions of the worm. Often it was eaten whole and alive, the young host becoming so distended as to be unable to withdraw his legs or head into the shell. One of my very small specimens (carapace length $1 \frac{1}{16}$ inches) attacked and devoured, whole and alive, an earthworm nearly twice its length in exactly sixtyfive seconds.

Enemies.- Predaceous mammals undoubtedly destroy a certain number of eggs each year, but as the young immediately seek the pond bottoms, they are exposed only to large predaceous fish which are uncommon in these localities. One young specimen which I had in eonfinement developed a white tumor-like mass on one of its front legs. On removal a smooth, bleeding surface was left. Under the microscope this tumor mass showed many layers of epithelial cells, and in the center a form suggesting one of the Filariae was found. It may be that these turtles are infested with some specific parasite.

Economic Importance.- The Musk Turtle has no direct commercial value. As a scavenger, however, it plays its part in the economy of Nature. 
Kinosternon subrubrum (LACÉPÈDE).

\section{Mud Turtle; Fresh-water Box Terrapin.}

Plate 22.

Testudo subrubra Lacépède, Hist. Nat. Quadr. Ovip. Serp., 17S8, vol. 1, Synops. méth., tabl. betw. pp. 618 and 619 (comp. p. 132).

Kinosternon subrubrum Stejneger and Barbour, Check List No. Amer. Amph. and Rept., 1917, p. 112.

The Mud Turtle is very closely allied to the preceding Musk Turtle, differing chiefly in the formation and size of the plastron.

Size.- Adult specimens seldom exceed a carapace length of four inches. The plastron is nearly as long as the carapace. The measurements of a specimen in the Museum of Comparative Zoölogy at Cambridge, Massachusetts, are: length of carapace, $3 \frac{3}{4}$ inches; width of carapace, $2 \frac{1}{2}$; length of plastron, $3 \frac{5}{8}$; width of plastron at anterior hinge, $1 \frac{15}{16}$; length of anterior hinge, $1 \frac{1}{8}$; length of posterior hinge, $1 \frac{1}{4}$; width of bridge, $\frac{11}{16}$; width of head, $\frac{13}{16}$.

Color.- The upper shell is dull brown, the shields sometines having black margins. The plastron is light brown or yellowish. The head is brown with numerous yellow spots on the neck, sometimes arranged in two lines as in the Musk Turtle, although these markings are not constant. There are small horny papillae under the chin. The extrenities are brown.

Description.- The carapace, which is completely ossified, is broader and flatter than in the preceding species, being wider in front in the female than in the male. The head also is not as large proportionately as in the Musk Turtle. Both jaws have sharp cutting edges. The plastron in this species is large and nearly covers the under part of the body. It is composed of eight plates, arranged in pairs, through which a median suture extends without interruption. The two middle pairs of plates extend entirely across the body and are sutured to the carapace, thus forming a long bridge. The anterior and posterior pairs of plastral plates are broad and rounded and are joined to the central pairs by flexible hinges which allow the two ends of the plastron to be drawn up against the carapace thus protecting the soft parts. These hinges tend to ossify in very old specimens. The movable parts of the plastron in this species differ from those of the true Box Tortoise (Terrapene) in that in the latter one hinge divides the entire plastron transversely into halves which swing upon each other, while in the former they swing upon "an immovable transverse beam" which is united by bony sutures to the carapace. The plastron in Terrapene is united to the carapace by ligamentous attachments only. The feet are short and round, and the toes are well webbed. The tail is small and short, but longer in the males, and terminates in a horny nail-like point. In young specimens the carapace shows three blunt keels. 
Geographic Distribution.- The range of this turtle is considered to extend from New York, south to the Gulf of Mexico, (exclusive of the peninsula of Florida) and west to the Mississippi Valley.

New England Records. - As will be noted, the range given extends as far north as New England, but does not enter it. The turtle has been reported from Long Island, however (Murphy, 1916), and it is not unreasonable to assume that occasional individuals, at least, occur in southern Connecticut. Mr. E. F. Bigelow of Sound Beach, Connecticut, writes me that he thinks he has seen it in that vicinity. Stejneger and Dickerson report, however, that no New England records as yet exist in the collections of the United States National Museum or American Museum of Natural History. No New England records exist at the Boston Society of Natural History nor at the Museum of Comparative Zoölogy at Cambridge. Linsley (1843), however, reports one specimen taken by himself at Stratford, Conn., on Nov. 13, 1843, and says: "probably never before found in New England." He adds: "This is the Testudo Pennsylvanica, of Edwards, the Cistuda Pennsylvanica, of Say, the Emys Pennsylvanica, of Harlan, and the Kinosternon Pennsylvanicum, of Holbrook and Dekay. Shell, length 4 inches, width 2.6, depth 1.5 inches. It is narrower in proportion to its length, than any of our tortoises, except Sphargis coriacea. The posterior portion of the shell being almost perpendicularly elevated, constitutes a very distinguishing feature of this animal, and will prevent its being taken for any other species. It is however the most nearly allied to the Sternothoerus odoratus." This species has been reported as occurring in Massachusetts, by Hitcheock ${ }^{1}$ in 1833 , but the record was later questioned by Holbrook. ${ }^{2}$ In spite of its doubtful occurrence, I have included it in the Chelonian fauna of New England.

Environment.- These turtles inhabit muddy bottoms of ponds and streams, although they are not as strictly aquatic as the closely related Musk Turtle. They also have been observed to inhabit brackish marshes.

Numbers.- This species is considered not as common anywhere within its range as the preceding.

Breeding Habits.- It lays from three to five eggs not far from the water's edge in the manner customary among turtles. Wright has described a nest in rotten wood by the side of a dead log, the eggs (three) being deposited at a depth of three inches. The eggs have "the form of a rather elongated ellipse, with very blunt ends." The shell membrane, which is smooth and glazed, is, according to Agassiz (1857, vol. 2, p. 507), two-thirds as thick as in the Chelydra serpentina, and is brittle. He reports that a female kept in confinement "did not

\footnotetext{
${ }^{1}$ Hitchcock, Edward. Report on the Geology, Mineralogy, Botany, and Zoölogy of Massachusetts, 1833 , p. 552. He lists it here as "Pennsylvanica," In 1835, in a later edition under Catalogues of the Animals and Plants of Massachusetts, p. 14, he lists it as "Pennsylvanica, Box Turtle."

${ }^{2}$ Holbrook, J. E. North American Herpetology, 1842. He says it extends only "to lat. 41 degrees," and thinks Hitcheock mistook $K$. odoratum for it.
} 
lay until the seventh of October (1856), and then only brought forth a single egg." It inust be remembered that with captive turtles this habit is always retarded.

Habits.- W. H. Smith (1879) states that the Mud Turtle is less of a water turtle than others of the family, that it "burrows in drier ground, where it also hibernates."

In this connection Wetmore and Harper (1917) relate the following: "Nareh 25, 1917, was one of the first warm, bright days of spring in this vicinity. At 10:30 A. M., while working along the border of one of the Potomac marshes two miles below Alexandria, Va., we picked up a specimen of Kinosternon pennsylvanicum (Bose) in a small thicket of Smilax. Casual examination showed that the animal had but recently come out of its place of hibernation. Its carapace and limbs were encrusted with freshly dried earth, and the turtle seemed more sluggish than usual in its reactions while being handled. This excited our curiosity, and a short search revealed an opening beneath some dead leaves, only eight or ten inches from the spot where the turtle was discovered. After clearing away the thorny entangling stems of green-briar, we were able to make a careful examination of the hole, and found that it had unquestionably been used as a place of hibernation.

"The location chosen was about 50 yards distant from the marsh, in a shallow, furrowlike depression leading down through a gently sloping field. Broom-sedge covered most of the field, and a varied growth of shrubs and low trees was seattered through it. The exeavation was near the center of a low but dense growth of Smilax four or five feet in width, so that it was protected on all sides from the approach of predatory animals. The soil here was a sandy loam, through which the tough roots of green-briar grew in interlacing lines. The earth was friable and easily thrust aside save where the root growths prevented. The opening through which the turtle had emerged was roughly elliptical in outline. It was broad enough to admit the turtle easily with its legs extended. The burrow descended at an angle of about 45 degrees, and was approximately $9 \frac{1}{2}$ inches deep. The pitch of descent decreased toward the lower end, and at the bottom the excavation was slightly widened, as if the turtle might have rested with its body at right angles to the burrow. The main part of the burrow was open, though drifting leaves held by the Smilax stems had covered the entrance. In the lower part, however, was a mass of earth containing a considerable amount of water, so that it formed a stiff mud paste, which was very cold to the touch. So far as we could tell, the turtle had lain encased in this mud during its hibernation. The tunnel walls were dry.

"Several fresh shells of Aromochelys odoratus and one or two of Kinosternon pennsylvanicum were seen lying about in wooded areas bordering this same marsh. Thus the emergence of these turtles from hibernation had been of interest to others. The shells had been eaten out and left lying on logs, stumps, or the ground. Apparently this was the work of erows. American Crows were feeding here in abundance, and with them were a few Fish Crows.

"The turtle that we had found was taken home and placed in a basin of water. For 
several minutes it made no movement save to emit a series of bubbles from its nostrils, or to close and open an eye. Then it proceeded to extend and retract its neck slowly. At the same time it drew water into its mouth, and apparently drank. The jaws were opened and closed slowly. In a short time movement of the jaws ceased, but the turtle continued to draw water into the mouth and then expel it, the outdriven current setting up eddies that agitated the silt on the bottom of the basin. In a few more minutes the turtle became more alert and swam and walked about, thrusting its head to the surface.

"When the turtle was first found, its skin was dry and wrinkled. The animal was able to retract its head and tail and to close both lobes of the plastron completely. By the following morning the skin about its legs was smooth and swollen, and it was unable to withdraw completely into its shell, owing to absorption of water.

"On this morning (March 26) the turtle was killed and an examination of the viscera was made. It was found that the stomach contained a small anount of whitish mucus, part of which was mixed with earth. The small intestine was contracted and entirely empty. The upper third had thickened walls and was much larger in diameter than the lower portion. The lining of the intestinal canal for the space of an inch above the point of entrance of the hepatic duct was stained a deep brownish orange. This apparently was due to bile. The gall bladder was filled, and the bile, very dark green in color, was thickened to the point of viscidity, so that portions of it could be drawn over the enameled surface of the dissecting tray with a probe. Below the hepatic duct, the walls of the intestine were pale. An orange tint appeared four inches above the caecal expansion and increased in intensity to the point of junction of large and small intestines. The caecum was empty. In the rectum were four rounded masses of firm, hardened mucus, each as large as a pellet of number 8 shot. The cloaca was empty and completely contracted. The animal seemed to be normal in flesh, and small masses of orange-yellow fat persisted along the dorsal wall of the body cavity and in the region of the pelvic arch. Apparently metabolism had been in abeyance during the period of hibernation."

The aninal dwells mostly in the water, however, where it prowls about the muddy bottom in search of food. Agassiz says (1857, vol. 1, p. 350): "The slender legs are ill fitted for traveling on dry land, but easily carry the body through the water over its bottom. When surprised away from the water, the animal seeks the nearest hiding-place; if danger is close at hand, it quickly withdraws the exposed parts into the shield, and, if pressed still farther, it resorts at last to biting, not throwing the head quickly and forcibly out as the Chelydroidae do, but stretching it out rather slowly towards the assailant, and then snapping the jaws forcibly upon it."

This species exudes a slight musky odor (not as pungent as in the Musk Turtle), which according to Holbrook is "not disagreeable." In swimming, its movements are graceful and deliberate. 
Food Habits.- The Mud Turtle is chiefly carnivorous. Fish and coleopterous insects were found in the intestines of two speeimens examined by Agassiz. He says (1857, vol. 1, p. 350): "They remind us of the Insectivora among Mammalia, the rapacious habits of which are also in strange contrast with their small size and feebleness." In captivity these turtles have thrived on chopped fish, earthworms, and raw beef (Ditmars, 1907).

Enemics.- Its eggs undoubtedly are devoured by such mammals as the racoon, skunk, and weasel, and by certain snakes, but the musky odor of the adult is probably sufficient to discourage a very persistent attempt to get the animal out of its shell. The following is an unusual observation. Mr. J. T. Nichols (1914a) observed a large Blue Crab "firmly holding a Mud Turtle (Kinosternon pennsylvanicum) of perhaps more than half its size, one of whose feet waved helplessly above the surface. The crab probably had it by the neck, and the encounter might well have ended disastrously if not interrupted."

Economic Importance.- These turtles are scavengers, although of course on a relatively small scale. They have no food value. 


\section{Family TESTUDINIDAE. \\ Chrysemys picta (ScHNeIDER). \\ Painted Turtle; Mud Turtle; Soldier Turtle.}

Plate 23.

Testudo picta Schneider, Naturg. Schildkr., 1783, p. 348.

Chrysemys picta Gray, Cat. Shield Rept. Brit. Mus., Mar. 8, 1856, pt. 1, p. 32 (part).

The Painted Terrapin or Turtle is probably the best known of any of the New England Chelonians.

Size.- This species is one of the smallest of the genus, the carapace not usually exceeding six inches in length. A female in my collection measures: length of carapace in straight line, $5 \frac{1}{2}$ inches; length following curve of carapace, $6 \frac{1}{8}$; width in a straight line, $3 \frac{7}{8}$; width following curve of carapace, $5 \frac{1}{4}$; height of carapace, $1 \frac{7}{8}$; sternal length, $5 \frac{3}{8}$; sternal width, $3 \frac{5}{8}$.

Color. - The carapace is dark olive-brown or sometimes black, the neural and costal shields being conspicuously margined with pale yellow bands. The marginals are red with black and yellowish central markings. The plastron is a uniform yellow. The head is black and has a pair of large yellow spots behind the eyes and another smaller pair on the occiput. Underneath, the throat and neck are marked with yellow stripes which change to red on the base of the neck, limbs, and tail. Very young specimens have a bright yellow stripe running longitudinally through the nuchal and neural shields, but the yellow margins are not present.

Description. - The characteristic structures of this turtle are the flat carapace, which is very smooth, and without any trace of a keel; the immovable plastron with a strongly developed bridge; the skull with a broad, complete lateral temporal arch; the notch in front of the horny sheath of the upper jaw on each side of which the edge of the sheath projects somewhat to form "lateral teeth"; the broadly webbed feet; and the short tail. The nuchal shield is long and narrow with its anterior edge finely serrated. Some of the marginal plates also have serrated edges. Males may be distinguished by the position of the anus, which opens beyond the border of the carapace.

Growth.-Agassiz (1857, vol. 1, p. 292) in his monumental monograph worked chiefly with this species, and the rate of growth year by year has been carefully determined and recorded by him, as shown on p. 369 .

In explanation of this table he says: "As Turtles lay their eggs in the spring, the specimens selected for examination were all collected in the spring; the starting point of comparison is, therefore, really the second year of their development. However, as the eclosion takes place 
only late in the summer, the young had only been hatched six months when picked up, though they are considered here as one year old, on account of the long period of incubation. Moreover, there is very little difference between specimens recently hatched and those collected the following spring.

Table showing Suecessive Changes in the Rclative Dimensions of the Body in Chrysemys picta.

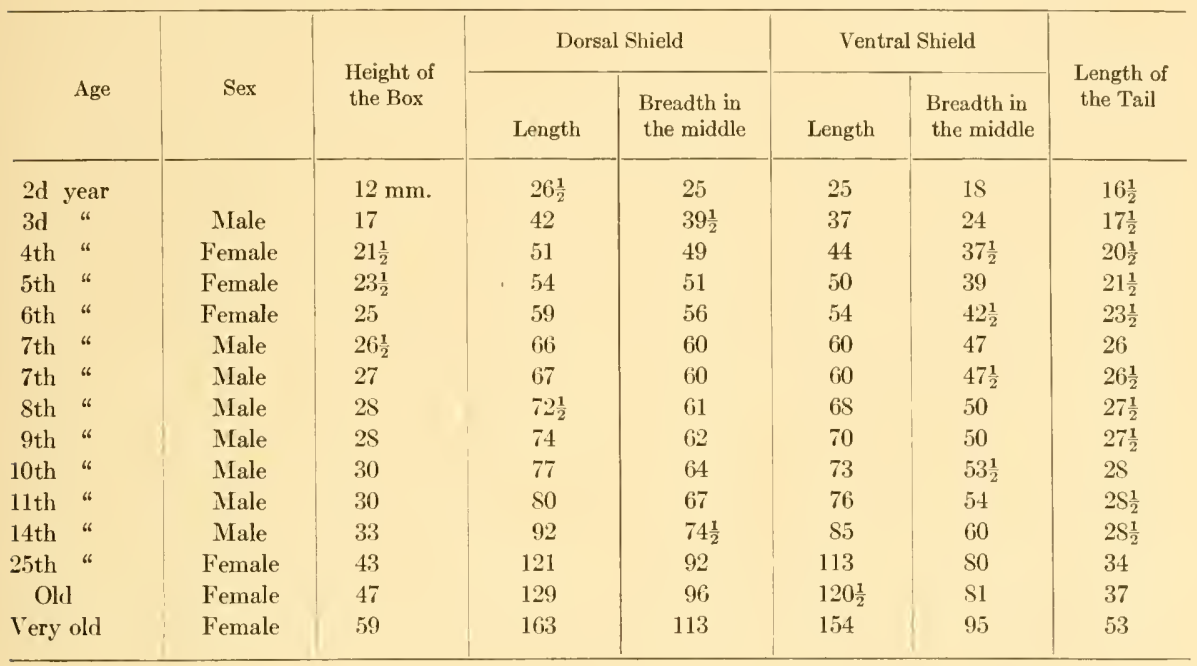

"After the seventh year, it is much more difficult to distinguish the age of those Turtles, which, like Chrysemys picta, have a perfectly smooth epidermis, than during the earlier years. I have, however, been able to determine it with tolerable precision, by collecting large numbers of specimens at the same time and in the same season, and assorting them according to their size, and comparing the sets thus formed with specimens of other species, in which the successive lines of growth indicate the number of their years. During the first six or seven years the rate of growth is so uniform that numerous specimens collected at the same time are readily arranged in sets of the same age, simply by the difference they show in their size."

In moulting, the skin of each shield is shed separately, and resembles a thin sheet of mica.

Geographic Distribution.- - Its range is eastern North America, extending northward into southern Canada, and southward to Georgia. West of Ohio and Indiana it is replaced by a closely allied species.

New England Records. - This species is reported from all of the New England States. Verrill (1863) says it is very common in the vicinity of Norway, Oxford County, Maine, and 
is found in all parts of the State. Thompson (1842) reports it from Vermont and calls it "our most common species." Huse (1901) reports it as the most common species in New Hampshire. Linsley (1843) records it from Connecticut. Hitcheock (1835) and Storer (1840) have reported it in Massachusetts.

Numbers. - From the foregoing records it appears that this turtle is the most common of all our New England species. I have certainly so observed it for eastern Massachusetts.

Habitat:- Ditches, ponds, and streams. This turtle, however, is not strictly aquatic. I have taken individuals in salt marshes. The epidermis of such specimens, especially over the carapace and plastron, was always coated with a rusty deposit.

Breeding Habits.- The actions of this turtle during the mating season have been observed by several writers. Pycraft (1914, p. 168) says: "In certain abnormal, sexually poisoned individuals among the human race it is well known pleasure is derived from flagellation. There is but one instance known to me where this obtains as a normal accompaniment of desire among the lower animals, and this occurs in one of the Painted Terrapins (Chrysemys picta), whose finger-nails are produced into long, whip-like ends. I had the good fortune to witness their use one day when in the Reptile House at the Zoölogical Gardens in London. The unusual activity of a male of this species was the first thing to attract attention to his movements. Watched more closely, he was found to be dodging a female and making frantic efforts to swim round so as to oppose her path. This done, he closed up and immediately commenced to apply the bastinado to her head. The movements were so rapid that nothing more than a blurred image of these strange whips was visible. As soon as she escaped his attentions, he set about circumventing her again, and again succeeded: and this most extraordinary performance was repeated many times during my watch."

Wyman (quoted by Agassiz, 1857, vol. 1, p. 300) had "the rare opportunity of watching two Chrysemys picta while making love, and he saw the male caressing and patting the head of the female with its fore feet for several minutes." The males especially become very animated under the stimulus of mate-hunger.

In Massachusetts the Painted Terrapin lays its eggs between the 11th and 25th of June and, as first recorded by Louis Agassiz, always in the late afternoon or evening (quite the opposite of the Snapping Turtle). This species lays from five to seven, or sometimes eight eggs. Their form is that of an "elongated ellipse." The shell is not highly calcareous and is therefore soft when fresh. The dimensions of the eggs are from 26 to $30 \mathrm{~mm}$. by 16 or $17 \mathrm{~mm}$.

Thoreau (1884, p. 179) gives the following minute description of this turtle's nesting habits: "June 18, 1855. To Hemlocks... At 3 P. м., as I walked up the bank by the Hemlocks, I saw a painted tortoise just begiuning its hole. Then another a dozen rods from the river on the bare, barren field near some pitch pines, where the earth was eovered with cladonias, cinquefoil, sorrel, etc. Its hole was about two thirds done. I stooped down over it, and to 
my surprise, after a slight pause, it proceeded in its work directly under and within eighteen inches of my face. I retained a constrained position for three-quarters of an hour or more for fear of alarming it. It rested on its fore-legs, the front part of its shell about an inch higher than the rear, and this position was not changed, essentially, to the last. The hole was oval, broadest behind, about an inch wide and one and three-quarters long, and the dirt already removed was quite wet or moistened. It made the hole and removed the dirt with its hind legs only, not using its tail or shell, which last, of course, could not enter the hole, though there was some dirt on it. It first scratched two or three times with one hind foot, then took up a pinch of the loose sand and deposited it directly behind that leg, pushing it backward to its full length, and then deliberately opening it and letting the dirt fall. Then the same with the other hind foot. This it did rapidly, using each leg alternately with perfect regularity, standing on the other the while, and thus tilting up its shell each time, now to this side, then to that. There was half a minute or a minute between each change. The hole was made as deep as the feet could reach, or about two inches. It was very neat about its work, not scattering the dirt about more than was necessary. The completing of the hole occupied perhaps five minutes. It then, without any pause, drew its head completely into its shell, raised the rear a little, and protruded, and dropped a wet, flesh-colored egg into the hole, one end foremost. Then it put out its head again a little slowly, and placed the egg one side with hind foot. After a delay of about two minutes it again drew in its head and dropped another, and so on to the fifth, drawing in its head each time, and pausing somewhat longer between the last. The eggs were placed in the hole without any particular care, only well down flat, and each out of the way of the next. I could plainly see them from above.

"After ten minutes or more, without pause or turning, it began to scrape the moist earth into the hole with its hind legs, and when it had half filled it, carefully pressed the earth down with the edges of its hind feet, dancing on these alternately for some time, as on its knees, tilting from side to side, pressing by the whole weight of the rear of its shell. When it had drawn in thus all the earth that had been moistened, it stretched its hind legs further back and to each side, and drew in the dry and lichen-clad crust, and then danced upon and pressed that down, still not moving the rear of its shell more than one inch to right or left all the while, or changing the position of the forward part at all. The thoroughness with which the covering was done was remarkable. It persevered in drawing in and dancing on the dry surface which had never been disturbed, long after you thought it had done its duty, but it never moved its fore-feet, nor once looked round, nor saw the eggs it had laid. There were frequent pauses throughout the whole, when it rested, or ran out its head and looked about circumspectly at any noise or motion. These pauses were especially long during the covering of its eggs, which occupied more than half an hour. Perhaps it was hard work.

"When it had done, it immediately started for the river at a pretty rapid rate (the sudden- 
ness with which it made these transitions was amusing), pausing from time to time, and I judged it would reach it in fifteen minutes. It was not easy to detect that the ground had been disturbed there. An Indian could not have made his cache more skilfully. In a few minutes all traces of it would be lost to the eye.

"The object of moistening the earth was perhaps to enable it to take it up in its hands (?), and also to prevent its falling back into the hole. Perhaps it also helped to make the ground more compact and harder when it was pressed down. (September 10. I can find no trace of the tortoise eggs of June 18th, though there is no trace of their having been disturbed by skunks. They must have been hatched earlier)."

Rogers (1917) describes the actions of a turtle which he observed laying her eggs, as follows: "She had dug a hole at least four inches deep (perhaps much more), and was laying eggs. I saw her lay three, at brief intervals. She would poke each one down among the others and pack it in with one or the other hind foot. After laying the last, she shoveled the sand back over them with her hind feet (which, normally so far apart, were brought to meet and even overlap), stamping and pushing it down, awkwardly, but so painstakingly and efficiently that when she had finished the spot was indistinguishable. The hole was less wide than deep, and the top eggs were under about an inch or two of sand. During the whole operation, the turtle's head (about half out), and body remained practically motionless, and I believe that she never saw her eggs, unless while I was away briefly she turned around expressly to look at them. All I have described (took place between five and six in the afternoon), she did while I stood close over her where she must have seen me. The animal had come about 120 yards from the pond, first through dense bushy growth (Chamaedaphne, etc.), then all the way across the open space where her track, fairly straight, was plainly visible."

It is not uncommon during the laying season, to run across individuals returning to the water at dusk, their hind legs and the posterior portion of the shell covered with loam. One female that I picked up as she was returning to the water at dusk after having deposited her eggs, appeared much agitated and showed a respiration rate of 40 per minute. I have found them along country roads in mid-afternoon at considerable distances from any pond or stream, evidently in search of a suitable nesting site. Thoreau has often observed them laying their eggs on "southerly sides of hills and banks" near water. The eggs are buried just deep enough to obtain the maximum heat and the most even temperature. This species does not begin to lay before the eleventh year of its growth.

Habits. - While this turtle must be classed as largely aquatic, it has a regular habit of leaving the water and basking in the sun, resting on tufts of grass, derelict logs, projecting rocks or other suitable perches, and is thus observed often and in considerable numbers. Apparently asleep, it always notes danger quickly and plunges into the water at the slightest alarm, approaching the surface again in a few moments with great caution. It becomes less timid 
as the season advances until by October, as the time for annual hibernation approaches, it is rather sluggish. When first captured it is vicious (especially young specimens), but soon becomes quite tame. It is a more delicate species in captivity than the more aquatic forms.

Food.- This species is omnivorous, feeding on small fish, tadpoles, aquatic insects, and their larvae, and various water plants. In the examination of eighty-six stomach contents of individuals of this species, Surface found: algae, moss, stems, leaves, seeds, grass, slugs, snails, mussels, dragon-flies, crickets, bugs, larvae of Lepidoptera, flies, beetles, rose-bugs, wasps, ants, fragments of fish and mammals. It apparently cannot swallow unless the head is under water and I have often watched indivicluals come up on the shore, pick up pieces of wheat or cracked corn (left there for ducks), return hurriedly to shallow water where they would submerge their heads and shake them vigorously as if swallowing such dry food was not an easy process. The stomach contents of one I recently examined consisted of vegetable roots and parts of beetles. In captivity they will eat table scraps of almost any variety. When kept in aquaria they often attack small fish or tadpoles.

Enemies. - This turtle is subject to attack from predatory birds and mammals much as other fresh-water turtles previously considered. Thoreau speaks of finding an eviscerated Painted Turtle at Concord. The turtle was still alive, the grass about it was trampled, and there was evidence of a previous struggle. He suggests a skunk, weasel, mink, or heron as the probable assailant. Turtles of this species in the same condition have been found by other observers. It is possible that crows may attack them in this manner.

Economic Importance.- Holbrook (1842, vol. 1, p. 78) states that its flesh is sometimes eaten but "not much esteemed." The small size of this species, however, prohibits its becoming of commercial value. 


\section{Pseudemys rubriventris (Le ConTE). \\ Red-bellied Terrapin; Slider; Cooter.}

Plate 24.

Testudo rubriventris Le Conte, Ann. Lyc. Nat. Hist. New York, 1S30, vol. 3, p. 101.

Pseudemys rubrizentris Loennberg, Proc. U. S. Nat. Mus., Nov. 15, 1894, vol. 17, p. 318.

The Red-bellied Terrapin is the largest fresh-water terrapin occurring in New England.

Size.- This species reaches a length (carapace) of twelve inches or slightly over. The dimensions of a male which I captured in Plymouth, Massachusetts, June, 1916, are: length of carapace (in a straight line), $10 \frac{1}{2}$ inches; length following curve of carapace, 11 ; width in a straight line, 7 ; width following curve of carapace, $10 \frac{1}{4}$; height, 4 ; sternal length, $9 \frac{1}{8}$; sternal width, $5 \frac{5}{8}$.

Color.- There is a wide variation in the color pattern of this turtle. In general the carapace is a mottled olive or brown with irregular transverse bands of deep red or black. The marginals have a reddish central band. The plastron is red or dark orange. Head, neck, and extremities are dark brown or black with irregular red and black lines, more marked on throat and neck. Individuals in young-adult life are more vividly colored than when very young or old.

Description.- The characteristics of this species are: the high and laterally constricted carapace, the strongly serrated upper and lower jaws, their very broad horizontal alveolar surface, and the prominent hooks on both sides of the median notch of the upper jaw. The carapace is fairly smooth (rugose in aged individuals) and is not keeled. The plastron is heavy and wide and is connected with the carapace by a strongly developed bridge. The tail is short. The feet are webbed and the toes possess very long claws; the front feet also possess a row of large scales on their outer edge.

Geographic Distribution.- This terrapin has a limited range. Holbrook (1842, vol. 1, p. 55) restricted it to the region between the Delaware River on the north and Chesapeake Bay on the south. It is now known as far south as Florida, west to eastern Ohio, and north to Massachusetts, whence it was reported by me in Copeia, no. 38, Dec. 24, 1916 . Dr. F. A. Lucas states that he has known of its occurrence in Plymouth since 1869.

New England Rccords. - The Red-bellied Terrapin has been known for some years to inhabit certain ponds in Plymouth County, eastern Massachusetts, where it remains localized. Nor is it recorded from any intervening point between Plymouth County and New York and New Jersey. It has been taken or observed in Gunner's Exchange, Hoyt, Island, 
Nigger, Hillfield, Boot, Upper West, and Mieajah Ponds, and reported from several other's. There are three Massaehusetts specimens in the Museum of Comparative Zoölogy at Cambridge, from the following loeations: (1) Upper West Pond, Plymouth County, Mass., colleeted Oetober, 1905, by F. A. Lueas; (2) Boot Pond, Plymouth, Mass., eolleeted July, 1912, by H. J. Thayer; (3) Gunner's Exehange Pond, Plymouth, Mass., eollected July, 1912, by H. J. Thayer.

In the eollection of the Boston Soeiety of Natural History there is one specimen eollected at Hillficld Pond, Plymouth, Mass., June, 1916, by myself.

Habitat.- Holbrook (1842, vol. 1, p. 55) in diseussing the habits of this speeies states that it is found in "streams and rivers of running water, generally preferring those with roeky beds." In the as yet unpublished "Survey of Inland Waters of Massachusetts," by the State Commissioners on Fisheries and Game, I find the following data regarding three of the larger ponds in which these turtles are abundant.

Gunner's Exchange Pond: "Greatest depth, $25 \mathrm{ft}$.; middle west shore, boggy; several wide sand beaches; botton, muddy."

Boot Pond: "Area 74 acres; greatest depth, $31 \mathrm{ft}$.; bottom, slight aecumulation."

Island Pond: "Area 50 aeres; bottom, pebbles, stone, gravel, and brown mud." Thus it appears that a roeky bed is not an essential factor in its environment.

Numbers. - In the eentral portion of its range it is suffieiently eommon to be sought commereially as one of the substitutes for the more expensive Diamond-baek Terrapin.

Breeding Habits.-- The egg-laying habits of Pseudemys rugosa have been observed as follows by H. M. Smith (1904, p. 252): "The egg-laying season is in June and July, and the place where the eggs are laid is usually a eultivated traet, often a cornfield adjoining the water. It is probable that a field would always be seleeted, but when there is a high steep bank the eggs are of necessity deposited on the shore. The terrapins visit the fields only during egg-laying time and only for this purpose, and sometimes make their nests more than one hundred feet from the water. It has often been observed that six or eight terrapins will lay on the same shore or in the same field, their traeks being easily discernible in the moist or soft sand or loam. The nest is made in sand, elay, or loam, a sandy loam or sandy elay being most frequently chosen. The nest, which is shaped like a carafe, is dug by the female with her fore-legs[?]. Its size depends on the size of the animal or, what amounts to the same thing, on the number of eggs to be laid; an average nest would be four inches keep and four inches wide at the bottom, the opening being somewhat smaller than a silver dollar. When on the shore, the nest is always above high-water mark.

"All the eggs are laid at one time, and when the laying is completed, earth is scraped into and over the hole and packed tightly. The packing is aceomplished by the terrapin raising herself as high as possible on all four legs and then dropping heavily, by the sudden relaxation

${ }^{1}$ I am indebted to Mr. Henry J. Thayer for information concerning these turtles. 
of the extensor muscles. Immediately after covering the nest, the terrapin withdraws to the water.

"The size of the eggs varies somewhat with the size of the terrapin, but averages one inch by three-fourths of an inch. A six-inch terrapin lays ten or twelve eggs, while the largest terrapins, fourteen or sixteen inches long, lay as many as twenty-five to thirty-five eggs, possibly more. When a terrapin is disturbed while making a nest or laying, she will abandon the nest. On one occasion, when a terrapin was discovered over a nest in a cornfield, removed to see whether any eggs had been deposited, and replaced over the hole in the ground, it was found when the place was visited two hours later that she had left without laying any eggs. The eggs probably hatch during the summer, but on this point there have been no personal observations. The young, however, remain in the nest until the following spring (April 10 in one case), and when they emerge they are about the size of a twenty-five-cent piece. They go to the water at once."

Mr. Thayer sends me the following notes on the breeding habits of this terrapin at Plymouth, Massachusetts: "Breeding season in June. Lay about eight eggs, these deposited in excavation in sand about two or three inches deep; then make hole still deeper by sticking tail down and making round hole into which egg is laid. Eggs not laid in bunch, but each in separate hole made with tail; in the pan say six inches wide excavated first with legs. Whole clutch then covered with sand; wet down by the terrapin and place made difficult to trace by continuing the crawl farther for it may be more than one hundred feet."

Habits.- Red-bellied Terrapins are alert, active, and very shy. They are semi-aquatic and can be seen on bright, hot days sunning themselves on rocks in the water or on the shore, but always ready to disappear quickly at the slightest sign of danger. They live in comparatively deep water and are strong, rapid swimmers. They are occasionally seen at a considerable distance from water. Thus Dr. F. A. Lucas writes me that he found a large specimen in 1913, in the middle of the road half a mile from Crooked Pond, Plymouth, Massachusetts. Sometime during October (in Massachusetts) these turtles dig into the mud under shallow water and begin a period of hibernation which lasts until spring.

Food.- Their food is both animal and vegetable, consisting of snails, fish, tadpoles, crawfish, and aquatic vegetation.

Enemies.-H. MI. Smith (1904) observes: "Birds (especially crows) and other animals doubtless destroy some eggs. On one occasion a terrapin was observed over a nest on the shore, and a crow noticed on a dead tree near by. When the terrapin covered the eggs, concealed the nest, and withdrew to the water, the crow immediately dropped to the ground and began to dig into the nest. Before the observer, who was in a boat, could reach the shore, the crow had destroyed at least two of the eggs, seven others remaining."

Mr. Thayer reports finding on one occasion, in May, a specimen which had just died, in 
which the only indication of disease or injury was a nasal hemorrhage. He thinks numbers die from this affection each year.

Economic Importance. - This species is used commercially as a substitute for the more expensive Diamond-back Terrapin. A "Slider" weighing three or four pounds will bring from seventy-five cents to one dollar in the eastern markets during the proper season - the fall and winter months (Ditmars). They are kept in cold vats at the markets, to prevent any activity and resulting loss in weight. The flesh is said to have an excellent flavor. The eggs are sometimes eaten by people living near breeding grounds of these turtles. 


\author{
Graptemys geographica (Le Suevr). \\ Geographical Terrapin; Map Turtel. \\ Plate 25.
}

Testudo geographica Le Sueur, Journ. Acad. Nat. Sci. Phila., 1817, vol. 1, p. S6, pl. 5.

Graptemys geographica Agassiz, Contrib. Nat. Hist. U. S., 1857, vol. 1, p. 436.

Size.- Adult individuals average twelve inches in length. Ditmars (1907, p. 44) gives the following dimensions of a female: total length of carapace, $9 \frac{1}{2}$ inches; width of carapace, $7 \frac{1}{4}$; length of plastron, 8; width, flat portion of plastron, 4; width of head, $1 \frac{7}{8}$. Females attain a greater size than males.

Color.- The carapace is dull olive or brown, sometimes mottled and covered with an irregular reticulation of thin greenish or yellow lines, often indistinct. The under side of the marginals is yellow with a central blotch. The plastron is yellow with a pinkish tinge and a faint greenish mark across each half. The head and neck are striped with narrow yellow lines. There is an irregular yellow spot behind each ear. The tail is also striped with yellow.

Description.- The characteristics of this species are: a strong blunt keel running through the vertebral shields of the carapace, which is rather flat and flaring behind, with a somewhat denticulate edge; the great width of the smooth and flat horizontal alveolar surfaces in the jaws, and the "spoon-shaped dilatation of the extremity of the lower jaw"; the absence of a notch in the upper jaw; and the presence of large scales on the feet. The toes are short. The tail is longer in males than in females. The carapace of the young is strongly keeled and deeply notehed laterally and posteriorly.

Geographic Distribution.- The home of this species is the Mississippi Valley, ranging north through Pennsylvania and New York to Lake Champlain, and south to Oklahoma and northwestern Texas.

New England Records.- Thompson $(1842,1853)$ reports the Geographical Terrapin from Colchester, Vermont, near the mouth of the Winooski River. He says it is "quite common all along the eastern shore of Lake Champlain." It has not been reported elsewhere in New England. There are no specimens of this species in the Society's collection.

Habitat.- This species is considered more a river than a pond terrapin.

Numbers. - Throughout the central portion of its range, it is very abundant.

Breeding Habits. - Thompson (1853, p. 29) writes as follows regarding a specimen which he caught: "It was a female, containing 14 mature eggs in the oviduct, with about the same 
number, considerably developed, and innumerable small ones, in the ovaries. She was crawling very fast over the sandy plain, when taken, and was evidently in search of a suitable place for depositing her eggs. The form of the mature eggs was that of an ellipsoid, with one end a trifle larger than the other, and they differed not sensibly in size, being 1.4 inch long, 0.9 thick, and having their greatest circumference 3.7 in., and least, 2.9. The oviduct, containing the mature eggs, was taken from the abdomen, cut into three pieces, and laid aside, and, in the course of ten minutes, by repeated visible contractions, or throes, all the eggs were expelled from it." And again: "Another female of this species was taken, June 10th, 1846, near Clay Point, in Colchester. She was sitting over a hole she had excavated in the sand, in the act of depositing her eggs, and made no effort to escape when approached. Her oviduct was filled with mature eggs. I learn that in ploughing the sandy lands near this Point, nests of this tortoise, containing from 12 to 20 eggs, have been frequently laid open."

Habits. - This species is not ferocious, biting only when hard pressed. If attacked it prefers to retreat within the shell, the head being carried far back between the shoulders, the neck drawn in naked among the viscera, the legs folded between the inner parts of the projecting free edges of the shield, and the tail turned in laterally. In regard to the behavior of captive specimens, Ditmars (1907, p. 44) says: "Judging from his experiences with several hundred specimens of this turtle, both in the tanks of the reptile house of the New York Zoölogical Park and with specimens that were liberated in small ponds of the Park, the writer believes this to be a delicate species when removed from its native enviromment. It will eat chopped fish, meat and mealworms, also earthworms and various soft-bodied grubs, dragging all its food into the water and devouring it beneath the surface. The writer has also observed it to eat the edges of water-lily pads. None of the specimens liberated in the Park ponds passed through the winter alive - all floating up dead in the spring. The ponds appeared to be very favorable for the life of such creatures, as there was a soft mud bottom in which they could burrow for the winter. The experiment was continued for several winters, but with a like result. It appeared that some item of their food was lacking and without it they could not summon sufficient strength to pass the winter months."

Food Habits. - The peculiar structure of the jaws renders them especially adapted for crushing small mollusks, which constitute an important item of diet with this terrapin. Surface found crayfish in the stomach of one specimen. A certain percentage of vegetable matter also is eaten. The food is always swallowed under water.

Enemies.- In general the eggs and young of this terrapin are subject to attack and destruction from predatory animals much as are those of other species.

Economic Importance.- In portions of its range where abundant, this terrapin is collected and sold in the markets of the larger cities, as is the Red-bellied Terrapin, under the trade name of "Slider," as a substitute for the more expensive Diamond-back Terrapin of the salt marshes. 
Malaclemys centrata concentrica (Мнаw).

Diamond-back Terrapin; Chesapeake Terrapin; Terrapin.

Plate 26.

Testudo concentrica Shaw, Gen. Zool., 1802, vol. 3, p. 43, pl. 9.

Malaclemmys centrata conecntrica W. P. Hay, Bull. U.S. Bur. Fish., 1905, vol. 24, p. 16.

The Diamond-back Terrapin has by far the greatest commercial value of any of the semiaquatic New England turtles.

Size.-- The measurements of an adult female from Cos Cob, Conn., in the collection of the Boston Society of Natural History are: length of carapace in a straight line, $7 \frac{1}{2}$ inches; length following curve of carapace, 8 ; width of carapace in a straight line, $5 \frac{7}{8}$; width following curve of carapace, 7 ; height, $2 \frac{3}{4}$; sternal length, $6 \frac{7}{8}$; sternal width, $4 \frac{1}{4}$; nuchal shield, $\frac{3}{8} \times \frac{5}{16}$; length of bridge, $2 \frac{1}{4}$; width of head, $1 \frac{1}{4}$; length of tail, 2 . The weight of such a terrapin is about two pounds. Large specimens have a total length of 10 inches or slightly over, but such animals are now uncommon. The largest weight record is seven and one-half pounds. The length of the carapace exceeds that of the plastron, sometimes slightly, sometimes considerably, varying with the age and the species of the individual. The following table (after W. P. Hay, 1905) shows the variations for a number of specimens in this and certain other respects:

Size and Wcight of Diamond-back Terrapins.

\begin{tabular}{|c|c|c|c|c|c|}
\hline Locality & Sex & Bottom shell & Top shell & Weight & Supposed Age \\
\hline Chesapcake Bay & $\begin{array}{c}\text { Female } \\
" \\
" \\
" \\
" \\
" \\
" \\
\text { Male } \\
" \\
"\end{array}$ & $\begin{array}{c}\text { Inches } \\
\qquad 4_{\frac{5}{8}} \\
4 \\
4 \frac{5}{16} \\
4 \frac{13}{16} \\
5_{\frac{3}{4}} \\
6 \frac{5}{8} \\
7 \frac{3}{16} \\
4^{\frac{3}{4}} \\
3 \frac{11}{16} \\
4 \frac{7}{16}\end{array}$ & $\begin{array}{c}\text { Inches } \\
5_{4}^{\frac{1}{4}} \\
4_{\frac{1}{2}}^{\frac{1}{4}} \\
5_{4}^{\frac{1}{4}} \\
5_{1 \frac{5}{16}} \\
6_{4}^{1} \\
7_{\frac{1}{4}}^{1} \\
8_{4}^{\frac{1}{4}} \\
5_{1 \frac{11}{16}} \\
4_{\frac{5}{8}}^{\frac{5}{16}}\end{array}$ & $\begin{array}{c}\text { Ounces } \\
16 \\
10 \\
16 \\
16 \\
24 \\
48 \\
48 \\
17 \\
11 \\
15\end{array}$ & $\begin{array}{c}\text { Years } \\
7 \\
5 \\
6 \\
8 \\
6 \\
9 \\
10 \\
6 \\
5 \\
5\end{array}$ \\
\hline
\end{tabular}

Color. - While the coloration is variable, the carapace is usually grayish, with darker concentric markings on the shields and at the border. The plastron is yellow, blotehed or 
spotted with black. The head, neck, and extremities are gray, spotted with black, especially well marked on the neck.

Description.- Each shield of the carapace contains a number of concentric grooves, rising in step-like fashion. There is a well-defined blunt tuberculated keel. In old individuals these concentric rings completely disappear, leaving a smooth shell. There are no scales on the neck, upper arms, or thighs. The horny sheath of the jaws is straight, strong, and smooth; and the alveolar surface flat, broad, and without ridges. In his revision of the genus Malaclemys, W. P. Hay (1905) gives the following characteristics for this subspecies: "The carapace has in general the form of that of $M$. centrata, but is broader posteriorly and the marginal plates behind the bridge are seldom revolute; the plastron, also, is less convergent posteriorly; the plates of the carapace bear conspicuous concentric ridges, but those of the plastron are smoother, nearly always, however, except in some old individuals, showing at least traces of the lines of growth; the head is small, narrow, and neatly formed, the top of it flat, giving the nose a sharper appearance than is to be seen in the other form of this species.

"The color varies from uniform black to light brown, the latter always marked with darker concentric lines on each plate of the carapace and more or less blotched with darker on the plastron; the skin of the head, legs, and tail varies from nearly pure black to a very light greengray, the latter more or less marked with specks and short, crooked lines of black; the lips and top of the head are usually dusky, but individuals may be found with either or both white.

"The males resemble the females in the shape of the carapace, except that they are a little sharper posteriorly and the marginal plates are frequently a little revolute; the nose is much sharper than in the females."

Of the differences in sex he says: "The sexual differences . . . aside from the genital parts, are greater than in any other group of turtles known to me. The females are much larger than the males, they alone attaining the sizes usually cited in descriptions. Their heads are heavier and less pointed, their bodies deeper, and their tails shorter. The males seldom, if ever, reach a greater length than 5 inches; the shell is flatter than that of the female, and posteriorly more triangular; the marginal plates are apt to be revolute, the head is smaller, the nose sharper, and the tail longer."

Malformations have been commonly noted in this species. Coker (1910) found a great diversity in the scutes, also in the shape and size of eggs and of young, boldness, habits of feeding and of hibernating, in moulting, and in rate of growth. Females show a greater diversity than males.

Rate of Growth.- Measuring about one inch (length of plastron) at birth, young Terrapins increase in length about one inch each year for the first two years, slightly less for the third and about one-half inch for each of the fourth and fifth years. This rate is variable, however, few six-inch Terrapins being less than seven years of age. As to manner of growth, Coker 
(1906) says: "The manner of growth of the shell may first be briefly recalled. The horny shield of a terrapin is covered by thin, horny scales or scutes, disposed in several series. As the terrapin grows each scute extends its area peripherally, and commonly, in all directions. Thus, with each period of growth, a ring of new tissue is added, separated from the central area (areola) or the preceding ring, by a line of depression. While these rings are spoken of as 'concentric,' the term must be taken with a reservation, for growth is not equal in all directions. On the contrary, all scutes, except those of the anterior margins of carapace and plastron, grow more anteriorly than posteriorly; hence the rings are decidedly eccentric, the centre of each ring being (on most of the scutes) anterior to that of the preceding ring."

Geographic Distribution.- The Chesapeake Terrapin, separated as a subspecies of $M$. centrata, has a restricted range along the Atlantic coast from Massachusetts to Virginia or North Carolina, extending inland considerable distances along rivers. It has been reported in the James River above Jamestown, in the Potomac within four miles of Washington, and in the Hudson as far as Newburgh.

New England Records. - This Terrapin was first reported from Massachusetts in 1870 by J. A. Allen (1870) who records it from New Bedford, Wareham, and Nantucket Island. Bangs (1896) also reported it from Buzzards Bay in 1896. In 1913, in the Biological Survey of Woods Hole and Vicinity, it is also reported from the Wareham and Acushnet Rivers (Sumner, Osburn, and Cole, 1913, pt. 2, p. 774). A few years ago the Massachusetts Commissioners of Fisheries and Game exhibited two individuals taken in the salt marshes near Barnstable, Cape Cod, Massachusetts. This record establishes a new northern limit of distribution. In order to reach Massachusetts Bay from Buzzards Bay it seems probable that instead of travelling around the uninviting outer coast of Cape Cod these wanderers passed up the Monument River at the head of Buzzards Bay to points where its tributaries are in close proximity to those of the Scusset River, thence down that body of water to the Scusset marshes west of the town of Sandwich, and into Barnstable Bay (the present route of the Cape Cod Canal). This terrapin is also reported from Rhode Island, Connecticut, and Long Island Sound. In the collection of the Boston Society of Natural History are specimens from Wareham, Massachusetts, and Cos Cob, Connecticut.

Individual Range.- Judging from the numerous local races of these terrapins the individual range is probably small.

Habitat. - Primarily salt marshes and contiguous waters, extending at times well up rivers, although not beyond the tide line.

Numbers. - While the species is still common in certain more southerly portions of its range, the inroads of commercial turtle-hunters have greatly reduced its numbers. It is not common in New England.

Breeding Habits.-- The eggs are laid during May or June. The female digs a hole with 
her hind feet, five or six inches deep, and deposits from five to twelve eggs. The nests are made along the sandy edges of salt marshes or rivers, above the high-water line. Coker speaks of finding them on "sandy lumps" which the winds and waves have beaten up and which have been rendered stable by grass roots. He says (1906, p. 24): "The ground was dug up carefully, and, in three or four hours digging, seven nests were discovered. On one lump four nests, containing four, five, six, and seven eggs respectively, were found at depths of six to eight inches; except that the nest with four eggs (the only one not on the highest part of the elevation) was only three inches below the surface. This nest contained only small eggs. On the other lump were found three nests of about the same depths with two, five, and eight eggs respectively. Perhaps not more than one-half of the ground was dug, for it was not desired to disturb other nests. In each lump the higher part was 20 to 30 feet long by about 6 feet wide. With one exception, the nests were found on the highest part, which could be submerged only by a very high storm-tide." The eggs hatch in about six weeks. If the season is cold the incubation period is longer.

Habits.- The extensively webbed hind feet enable this terrapin to move about in the water with perfect ease, either floating with just the tip of the nose above the surface, browsing about the vegetation for food, or slowly moving along the bottom. Coker writes in this connection: "Some idea of the habits of the terrapin may be gained from a description of a typical collecting trip. While the tide is still ebbing, the collector starts out over the marshes carrying a stick with which to probe into the mud. The borders of the open places in the marsh are reached with especial care, since the terrapins are supposed to frequent these places for convenience in feeding at high tide. It requires the sharp eye of an experienced fisherman to detect the presence of a terrapin when all except, perhaps, the head and possibly a sinall part of the carapace is buried in the soft black mud of the grassy marsh. Often they are found merely by probing with the stick into suspicious depressions in the mud, or other places, which appear probable or possible hiding-places of a terrapin. On one occasion, a terrapin just found in the marsh was put back on the ground and allowed to crawl away. After a few minutes the path over the mud was traced. Winding about through the grass for a few yards, it passed through several watery depressions, and terminated at one just large enough to accommodate a crab that was the only apparent creature in it. Only the evidence of the fresh track terminating there led to further examination. The terrapin was found buried two or three inches in the soft mud underneath the crab." Hibernation begins soon after the advent of cold weather, but for some time it is broken on warm days. Eventually the animal buries itself completely at the bottom of some pool or stream and remains until spring. W. P. Hay (1905, p. 10) says: "Very soon after the winter sleep is over it sceks out others of its kind and the process of reproduction begins. Conjugation usually takes place at might or in the very carly hours of morning, and always in the water, the diminutive male being carried about on the back of the female." 
Hay thinks a certain amount of fresh water is necessary to the well being of this terrapin.

The following notes on association of sound or light with food are of interest. "Diamondbacks very quickly associate certain sounds or other impressions with food. Fish and crabs were fed them daily, these being chopped near the pen with a hatchet. After a few days, at the sound of the chopping, their heads would appear above their beds of weed. In time this sound, or similar sounds of rapping on the walls of the pen (whether or not food was present), became quite effective in bringing them out to the place of feeding, and thus they could be called from concealment whenever desired. Later, some were fed in the evening after dark for a period of about a week. Soon the appearance of a lighted lamp became associated with food and was sufficient to draw the animals out to the place of feeding, whether or not there was food at hand" (Coker).

Food Habits. - In the wild state its food consists largely of crustaceans and mollusks. Insects and the tender shoots and rootlets of marsh plants are also eaten. The following list (after Coker, 1906) of stomach contents of fourteen Diamond-back Terrapins killed shortly after capture is of interest.

\begin{tabular}{|c|c|c|c|c|c|}
\hline No. & $\begin{array}{l}\text { Litorina irrorata } \\
\text { Say (Snail) }\end{array}$ & Other Gastropods & Crabs & Annelids (Worms) & Remarks \\
\hline 1 & Fragments of 2 & & $\begin{array}{l}\text { Fragments of } 1 \text { (sp. } \\
\text { undetermined) }\end{array}$ & $\begin{array}{l}25 \text { pairs of jaws, ap- } \\
\text { parently of a species } \\
\text { of Nereis }\end{array}$ & $\begin{array}{l}\text { An abundance of } \\
\text { mud. }\end{array}$ \\
\hline 2 & & $\begin{array}{l}\text { About } 100 \text { very small } \\
\text { snails. } 1-2 \mathrm{~mm} .\end{array}$ & Fragments of $1(\mathrm{sp} ?)$ & & Little in stomach \\
\hline 3 & Fragments of 6 & $\begin{array}{l}\text { Fragments of } 3 \text { (Me- } \\
\text { lampus lineatus Say) }\end{array}$ & & & $\begin{array}{l}5 \text { pieces of grass } \\
\text { aggregating in } \\
\text { length } 32 \mathrm{~mm} \text {. }\end{array}$ \\
\hline 4 & & & $\begin{array}{l}\text { Tip of claw of crab } \\
\text { (sp?) }\end{array}$ & & \\
\hline 5 & Fragments of 153 & & $\begin{array}{l}\begin{array}{l}\text { Fragments } \\
\text { (Gelasimus) }\end{array}\end{array}$ & & $\begin{array}{l}1 \text { small piece of } \\
\text { grass (sp?) }\end{array}$ \\
\hline 6 & Fragments of 93 & & & & \\
\hline 7 & Fragments of 7 & & & & \\
\hline 8 & Fragments of 16 & & Fragments of 1 (sp?) & $\begin{array}{l}\text { Head and anterior } \\
\text { segments of Nereis } \\
\text { (irritabilis Webster?) }\end{array}$ & $\begin{array}{l}1 \text { bulb from sar- } \\
\text { gassum and a few } \\
\text { shreds of grass }\end{array}$ \\
\hline 9 & $\begin{array}{l}\text { Fragments of } 9 \\
\text { with many more }\end{array}$ & & Tip of claw (sp?) & $\begin{array}{l}\text { Setae and } 1 \text { pr. of } \\
\text { jaws of Nereis (sp?) }\end{array}$ & Shred of grass \\
\hline 10 & Fragments of 30 & $\begin{array}{l}\text { Fragments of a Me- } \\
\text { lampus lincatus Say }\end{array}$ & & & \\
\hline 11 & Fragments of 53 & & & & \\
\hline 12 & Fragments of 8 & & & & \\
\hline 13 & Fragments of 51 & & & & \\
\hline 14 & Fragments of 46 & & & & \\
\hline
\end{tabular}


Enemies.-Rats, crows, raccoons, minks, and hogs are known to destroy the eggs and young. If kept in a tank of fresh water, the Diamond-back Terrapin does not thrive, as its fleshy parts are soon attacked by a fungus, which presently kills the reptile. The infection may be killed by placing the terrapin in a bath of strong salt-water and keeping it there for forty-eight hours (Ditmars). Man, however, is at present the greatest enemy of this terrapin.

Economic Importance.- The popularity of the Diamond-back Terrapin as an article of food on account of the excellent flavor of the flesh, together with its rapidly decreasing numbers owing to the great inroads made by turtle-hunters, has raised its value to a point where artificial propagation under favorable conditions promises to become a profitable commercial industry. Several "terrapin farms" are now in existence. Terrapins are usually sold in market by length instead of weight, the measurement being made along the middle line of the lower shell, or plastron, from the lowest point in front to the bottom of the posterior notch. Speaking of prices, Coker says: "Six-inch terrapins bring, at wholesale, $\$ 30$. to $\$ 36$. per dozen; seven-inch terrapins may bring $\$ 60$. or more per dozen. I have been informed (by the sellers) of two sales, each of one dozen eight-inch terrapins. It is doubtful if there have been other sales of as many of this rare size at one time. In one case $\$ 96$. was received for the dozen, and in the other $\$ 120$. According to marketmen, frequently one or two selected terrapins are bought at retail at the latter rate or higher. The length is measured on the bottom shell. The larger terrapins are all females or 'hens.' The males or 'bulls' are rarely much over four inches in length. After many inquiries I have heard of one male that measured five inches, and of one female that measured as high as nine and one-quarter inches. 'Bulls' are usually quoted at about $\$ 12$. per dozen. Many undersized females are probably included as 'bulls."

These terrapins are not abundant enough at present in New England to be of commercial importance, although formerly they were "shipped by the barrel" from Buzzards Bay, Mass. (Bangs, 1896).

Extracts from an article on the Artificial Propagation of the Diamond-back Terrapin, by Hay and Aller (1913), issued by the U. S. Bureau of Fisheries are here given.

"The experimental work of the Bureau which forms the basis of this report has dealt with two of these species, namely, the Carolina and the Texas terrapins. The latter species, however, has been kept in captivity too short a time to furnish data of any value. The Carolina terrapins, on the other hand, have been in the pounds at Beaufort [N. C.] over four years, and young bred from them have reached the age of three years. It is believed that the results with any other species would have been essentially the same, and from what has been accomplished it appears probable that in favorable localities the business of breeding diamond-back terrapins will be profitable. If taken up by the States, the rapidly vanishing animal may continue to be one of the sources of income to our fishermen. 


\section{"Construction of a Breeding Pen.}

"In keeping diamond-back terrapins for breeding purposes the best results are to be obtained by the construction of a special inclosure, in which all the needs of the captives are provided for. The pens used for experimental purposes at Beaufort have proved to be admirably suited to this work, and they will therefore be described in full.

" The original pen, $(\mathrm{A}, \ldots$ ) ) is a rectangle 44 feet 6 inches by 48 feet, inclosed by a wall of concrete along the front and about two-thirds of the way back on the land; the remaining third of the sides and the back are made of plank. In the middle of one of the long sides, facing the water, is a gate 3 feet in width, extending from below low-water mark to the top of the wall and guarded by a grating of iron rods spaced about 1 inch apart. In the northwest corner of the inclosure there is a small pen for the reception of a few young terrapins. In the southeast corner is the egg bed, made by inclosing a space 16 feet square by a wall of planks and filling it with sand to a point about 12 inches above extreme high-tide mark. At one end of the egg bed a small pen was constructed as a trap for the newly hatched young ones, but as they refused to enter it, it has never been used. The top of the board walls of this pen and of the enclosure within it are provided with cap boards about 6 inches wide of dressed lumber to prevent the escape of any terrapins from the pen. This protection is extended to the egg bed also after the egg-laying season is over, so that the old terrapins are shut out from that part of the pen, and the young ones when hatched can not get into the water with the old ones.

"In the northeast corner a small platform of boards has been fastened a few inches below low tide level to furnish a place under which the terrapins can hibernate.

"The ground within the inclosure, with the exception of the egg bed and the part which remains covered with water at low tide, is quite thickly overgrown with marsh grass.

"After the pen just described was constructed, another of the same type was built adjoining it, $(B, \ldots$.$) , but nearly half the space within it was utilized at once for the construction$ of small inclosures to receive different lots of 50 to 100 young ones on which experiments were being tried and for the reception of a small lot of Texas terrapins. In each of the pens fresh water is supplied to all the inclosures by piping from an artesian well.

"In pen A, the area, after deducting the small pen and the egg bed, is about 1,550 square feet, and accommodates 18 male and 43 female terrapins. Pen B, after deducting the small pens and the egg bed, contains about 1,445 square feet and accommodates 65 male and 73 female terrapins.

"At a distance of about 20 feet from the walls these two pens are surrounded on the back and two sides by a wire fence of ordinary construction to prevent visitors from disturbing the terrapins or otherwise interfering with the experimental work, and as an additional safeguard a second fence of woven wire fencing has been added to the top of the walls all the way around. 
"In constructing a third pen a new location had to be selected, owing to the proximity of buildings to pens $A$ and $B$. The new pen faces the southwest and is somewhat larger, being 48 feet 6 inches wide and 64 feet long. The construction is the same as pens $A$ and B, except that the concrete wall extends entirely around the inclosure. The interior is divided into eight small pens and one large one, the former being for the reception of young terrapins and the latter for use as a breeding pen. A wire fence incloses three sides of this pen, so as to leave a clear space of about 15 feet all the way around. As yet this pen is not supplied with fresh water.

"While the pens at Beaufort are regarded as being eminently satisfactory and the best that could have been constructed in the places available for them, it should be understood that pens for commercial purposes could be built along other lines and probably of cheaper materials that would answer all the requirements quite as well. In many places along the coast there are ponds which could be inclosed by a tight fence made of boards and which could accommodate hundreds of adults and young. In constructing a pen of this type it would be necessary of course to set the fence back somewhat from the margin of the pond to prevent shipworms from attacking the submerged ends of the boards, or to throw earth, sand, or shells along the base of the fence. The boards, which need not be dressed, should be cut about 7 feet long and driven endwise about 3 feet into the ground, edge to edge. The fence should then be strengthened by having a board nailed horizontally along the top. A few strands of barbed wire above this might serve to keep out undesirable intruders.

"At one end of the inclosure, or if there are a great many breeding terrapins confined there, at various points about the margin of the pond, sloping sand beds should be provided for the nests and means should be found to prevent the terrapins from laying eggs anywhere else. (The most effective means is so to plan the inclosure that at high tide every part, except the egg bed, is covered with water.) These sand beds should be built up to a height of about 12 inches above extreme high-tide level, and the part of the fence near them should have an extra board, preferably of planed lumber, about 6 inches wide, extending outward like a shelf, a foot or more above the level of the sand. Provision should also be made for shutting off the sand bed by a low fence with a smooth cap board after the close of the egg-laying season. Somewhere about the pond there should be a separate inclosure for the young terrapins during their first year, and, if feeding the young through the first winter is to be attempted, some building that ean be warmed will be necessary...

"It will be observed that the inclosure for the young terrapins is cut off as completely as possible from the main pond and connects with the outlet of the pond by a separate gate. This will not be necessary unless a great many adults are kept, in which case the effort should be made to supply the young ones with clean water.

"The gates across the outlet of the pond may be made of iron bars, set close together in 
a wooden frame, or of heary galvanized wire netting. If netting is used, it should be amply protected against floating logs, etc., and should be replaced as soon as it shows signs of giving way.

"In case a natural pond is not available, a fairly satisfactory inclosure may be made on almost any low piece of ground, to which salt water can be conducted by ditches or through which some salt-water creek flows. In such a location, however, the labor of digging the ditches would be great and there probably would be much difficulty in inducing the females to deposit all their eggs in the sand bed provided for that purpose.

"Locations on high ground lemote from salt water, and in places where there is no tidal flow, would be absolutely unsuited to terrapin culture. Pens constructed in such places become filled with foul odors, mud, and filth.

"Whaterer type of inclosure is decided upon, at least 10 square feet should be allowed for each adult terrapin placed in it. A terrapin can live in less space than this, and future experiments may show that the animals will stand crowding; but up to the present a minimum of 10 square feet seems desirable.

"With respect to the proportions of dry land and water that are needed for best results very little can be said. Some land for at least a part of the time and some water all the time is desirable. The ideal condition is a swampy area of considerable size, all of which, with the exception of the egg bed, is covered at high tide, but from which at low tide the water does not entirely disappear. By having the area covered at high tide the females are compelled to use the sand beds for laying, and by having a part of the area exposed at low tide they are given an opportunity to crawl about and sun themselves.

"In constructing a terrapin pen, the possibility of muskrats digging under the fence and furnishing an avenue for the escape of the terrapins should be borne in mind. The common rat will eat the eggs and the young terrapins, crows are said to do the same, and kingfishers and herons are to be looked upon with suspicion. A tight fence, resort to traps or poison outside the pen, and the use of a shotgun when necessary will probably suffice to prevent any serious loss from these animals.

\section{"Selection of Breeding Stock.}

"Good terrapins for breeding purposes can usually be obtained from dealers. In many localities along the southern Atlantic coast there may be found individuals who make a business of buying terrapins as they are brought in by fishermen and impounding them until they can be sent to market. These persons can usually be depended upon to supply satisfactory stock. The prices asked vary considerably.

"It should be borne in mind that the market price of the different species is by no means the same, therefore in selecting breeding stock the effort should be made to get not only fully 
adult and healthy animals, but those of the kind desired. The fernales should measure 6 inches or nearly that, along the middle of the lower shell, and the males should be as near to 4 inches long as possible. Females 6 inches long are believed to have arrived at their period of full productivity, and those more than 6 inches long command an unduly high price. The males, which may be distinguished by their longer and larger tail and relatively smaller head, rarely reach a length greater than 4 inches.

"Common sense would dictate that preference be given to terrapins that have been kept under good conditions. Animals that have been kept in a filthy, crowded pen will probably need at least a year or two before beginning to lay their proper quota of eggs.

"In shipping terrapins to market it is customary to use barrels, in which the animals are more or less carefully packed until the barrel is full. The jarring and shaking about which the barrel is certain to receive often does serious injury to the animals in the lower layers and sooner or later may bring about their death. The purchaser of breeding stock should specify that the animals shipped to him shall be carefully packed in shallow boxes or that trays shall be used to separate the layers of terrapins. As soon as the shipment reaches its destination the package should be opened and the animals placed in the pen.

"With respect to the proportion of males and females that should be purchased, it must be said that little is known about the mating habits of the diamond-back terrapin. Such observations as have been made leave little doubt that copulation is promiscuous. At Beaufort one of the pens has less than half as many males as females, while in another there are nearly as many males as females, yet the advantage, if there is any, is in favor of the pen with the fewer males. The beginner might safely purchase twice as many females as males.

\section{"Care of Adults.}

"Under natural conditions the diamond-back terrapin is probably omnivorous, feeding on whatever nutritious matter it can find. The smaller crustaceans and mollusks are believed to form the major part of its diet, but in addition to those and similar items more or less vegetable matter is consumed.

"When kept in confinement the food supplied will necessarily vary more or less with the locality. At Beaufort the staple article is fish, but an occasional feeding of blue crabs or of fiddlers is given. The fish are purchased at one of the local fish houses and are those which are of some cheap variety or too small to be sold for cooking. The crabs are such as are caught in the trap net or seines in the ordinary work of the laboratory.

"The fish are cut into small pieces, and the crabs are thoroughly crushed before they are given to the terrapins, and quantities amounting to about 2 ounces for each adult are supplied every day during the season of activity, which, at Beaufort, extends from about April to December 1 . 
"At a few points along the coast blue crabs may be obtained at a sufficiently low cost to be utilized as terrapin food, but usually the cost is prohibitive.

"Corn meal is sometimes fed to terrapins, being made into a stiff mash and placed in shallow boxes about the pen. Cabbages and turnips, if sliced or mashed into fairly small pieces, will also be eaten readily. It must be remembered, however, that the proportion of nutritious material in most vegetables is small and a larger quantity must be given than when a meat diet is supplied.

"Whatever food is given should be fresh and in such shape that the terrapins can eat it. Entire fish, unless they are very small, will be eaten with difficulty, and a terrapin's jaws are entirely too weak to crush the shells and claws of the blue crab.

"From time to time reports have been received of the bad effects which have followed an attempt to feed terrapins on salt fish and salt pork, but at Beaufort salt fish is the only available food for the young terrapins during the winter and is sometimes fed to the adults. It is eaten, but apparently without relish, and does not appear to be as nutritious as fresh fish. Salt pork has not been tried. It can only be suggested that salt food be utilized with caution and when nothing else is to be had.

"In feeding, especially if crabs are used, it is desirable to feed regularly in the same place; the terrapins soon learn to come up for their meal and the litter which they leave can be cleaned up from time to time more easily than if it is scattered all over the pen. When fish is supplied, very little care is required to keep the pen reasonably clean, since practically all that is thrown in is eaten, and the remainder sinks into the mud or is carried out by the tide.

"It is a matter of dispute among those who handle terrapins whether fresh water is a necessity to the animals. At Beaufort, where a flowing well is close at hand, fresh water is supplied to each pen, and the terrapins come up to the water trough from time to time and drink. In other places the animals are kept for months without any other fresh water than that supplied by the rain and dew and apparently suffer no ill effects.

"At the beginning of cold weather the terrapins become more and more inactive and finally burrow into the mud and hibernate until warm weather comes again. Their period of hibernation depends entirely on the temperature, and in the late fall and early spring and even on warm days in the winter a few individuals may come out and crawl about. At such times some watchfulness is required on the part of the person in charge lest a sudden change so benumb the wanderers that they will be frozen before they can return to their winter quarters. The benumbed terrapins and even those apparently frozen to death will probably suffer no serious harm if they are put back promptly into their bed.

"When left to themselves the terrapins hibernate in rather deep water or in holes which they find or dig along the shore a few inches below low-water mark. As neither of these conditions is likely to be found in the arerage inclosure, some substitute should be provided. The 
most satisfactory shelter is made by nailing boards together to form a surface of sufficient size and supporting this on stakes about a foot above the bottom in some protected corner of the pen. The space beneath this should be filled with eelgrass. A platform of this kind, 3 feet wide and 5 feet long, will accommodate from 50 to 75 large terrapins without crowding, and three or four times that number if they arrange themselves in layers, as they are prone to do.

"So far as is known, diamond-back terrapins are not subject to epidemic disease, and after reaching the age of 2 or 3 years have no important enemy except man. There are few animals so resistant to abuse or possessed of as great recuperative powers, but they may be, and frequently are, killed by eareless shipping or by privations suffered in pens poorly adapted to their needs. Under some conditions, probably a general lack of sanitation, a sort of necrosis of the bone, especially of the plastron, has been noticed. This, if extensive, may cause death, but the disease may usually be checked and the recovery of the affected individual assured if it be placed in a clean and not overcrowded pen.

"From what has been said it will be seen that the care of the adult terrapins presents very litile difficulty and that in suitable localities the cost of feeding is so small as almost to be negligible. If supplies are reasonably close at hand and the pen is well arranged, a man should be able to care for several thousands of the animals.

\section{"The Eggs.}

"When ready to deposit her eggs the female terrapin selects a suitable location, if one can be found, and prepares a 'nest' by scooping out a jug-shaped hole with her hind feet. The hole is about 8 inches deep and 5 or 6 inches in diameter at the widest part. She then backs as far as possible into the hole and drops her eggs. She next carefully replaces the sand or earth, packs it down, conceals the spot by crawling back and forth over it, and goes away, leaving the eggs to their fate. There is no reason to believe that she ever revisits the spot or takes the slightest interest in her offspring after they have hatehed.

"In case a suitable nesting place can not be found, the eggs will be dropped wherever the terrapin happens to be, and it has been observed at Beaufort that if the sand bed becomes too dry nests will not be made. This difficulty has been met by sprinkling the egg bed with a hose during periods of excessive drought.

"The egg-laying season begins as soon as the weather beeomes warm and lasts for several weeks. At Beaufort the earliest date on which laying has been observed is May 6 and the latest date July 31. It is generally believed that only one set of eggs is deposited in a season, but certain observations have been made which support the idea that some of the terrapins, at least, lay more than once. The average number of eggs found in a nest is 8 or 9 ; as many as 
12 or even 15 or 16 have been found, but it is probable that these large numbers are the product of more than one female.

"Under natural conditions the nests of the diamond-back terrapins are so widely scattered that there is little or no danger of one individual interfering with another, but when many of the animals are confined together in a pen the possibility of this should be kept in mind. At Beaufort a few eggs are lost each season from this cause, and it can not be prevented except by keeping a continual watch over the egg bed and throwing some protection about each nest as soon as the female has left it. As such care is out of the question, the loss is minimized by making the egg bed as large as possible.

"After the eggs have been laid they should not be disturbed. Under some conditions terrapin eggs will not be injured by being moved from the nest and even shipped considerable distances. Usually, however, the most careful handling has the effect of reducing the percentage of the hatch 50 or even 75 per cent. It cannot be regarded, therefore, as good practice to dig up the eggs for the purpose of removing them to some other place for hatching. The nests should be carefully protected from depredations by rats and other vermin, and trampling over the egg bed by the keeper or by inquisitive visitors should be avoided.

"If the egg bed is properly constructed, there is no danger of injury from excessive moisture, as the rain water will drain away through the sand very quickly. There is rain enough in ordinary seasons, also, to prevent the damage that may come from excessive drought.

"In excessively hot and dry weather it has been the practice at Beaufort to throw a light covering of leafy brush on the beds, but the purpose has been to afford some protection to the newly hatched young ones rather than to the eggs. To this same end no particular effort is made to eradicate the growth of marsh grass which springs up, notwithstanding the fact that the sharp-pointed underground stems of this plant sometimes puncture a few eggs.

"If rats are numerous in the vicinity of the inclosure they may cause considerable loss by digging up the nests and eating the eggs or the newly hatched young ones. The holes they dig are easily seen, and a quantity of poisoned bait scattered about outside close to the pen and traps, set at suitable places, will usually control the nuisance.

"The great danger in most localities is an unusually high tide that may flood the bed and keep the eggs covered with water for several days. The effect of such a protracted immersion may be most disastrous, and the only preventive is to see that the laying bed is made right in the beginning.

"As soon as practicable after the close of the laying season the adult terrapins should be kept off the egg bed. This may be clone conveniently by setting a plank on edge along the front of the bed. The top of this plank, as well as all the fences surrounding the egg bed, should have a projecting cap board about 4 or 5 inches wide to prevent the young terrapins from leaving the egg bed. The time required for the eggs to hatch varies slightly with the season, but has been found to average about eight or nine weeks. 
"Under proper care and with healthy stock the percentage of hatched eggs is remarkably high. The number of eggs produced by a terrapin is not very large, however, and after being placed in captivity apparently a season or two must elapse before the full quota of eggs is laid.

"The following table shows the results attained at Beaufort:

\begin{tabular}{|c|c|c|c|c|c|c|c|}
\hline & \multicolumn{4}{|c|}{ Pen A (original lot). } & \multicolumn{2}{|c|}{$\begin{array}{l}\text { Pen B (second stock } \\
\text { placed in inclosure). }\end{array}$} & \multirow{2}{*}{$\begin{array}{c}\text { Pen C (Texas } \\
\text { terrapins). } \\
1912\end{array}$} \\
\hline & 1909 & 1910 & 1911 & 1912 & 1911 & 1912 & \\
\hline Females & 41 & $\ldots$ & 43 & 43 & 70 & 70 & 34 \\
\hline Males & 23 & $\ldots$ & 18 & $1 \mathrm{~S}$ & $44-46$ & 45 & 32 \\
\hline Eggs & (a) & 295 & 513 & 650 & $\ldots \ldots$ & 619 & 124 \\
\hline Eggs hatched $(b)$ & $12-13$ & $2 S S$ & 421 & 538 & 39 & 583 & 104 \\
\hline
\end{tabular}

$a$ Eggs not found.

$b$ Twelve young terrapin found in the pen, no eggs observed; 1 of these died shortly after; 1 young found the next spring placed with this lot.

\section{“Care of the Young Terrapins.}

"The first young terrapins may be expected toward the middle of August, and from that time on a few of them will be seen from time to time crawling about the bed. They will remain above ground for only a short time, but during that time if there is any avenue of escape they are pretty certain to find it.

"To one who is familiar only with the adult animals the climbing ability of the young ones is astounding. They can ascend to the top of a rough-board fence with ease and, by selecting a corner in which to cling, can make their way over a concrete wall 2 or 3 feet high. It is not certain that a cap board of rough lumber will stop all of them, but dressed lumber or sheet metal affords them no foothold, and one of these materials should be used in this way to protect the entire egg bed.

"The young terrapins that are noticed crawliug about should be picked up and placed in tubs or tanks where they can be kept in the shade and provided with water and food. If left to crawl about, they are likely to be injured by the heat.

"The majority of the young ones appear to remain in the nests and under uatural conditions would probably not emerge until the following spring; but to allow this would subject them to many dangers, and they should be dug up. It is well to postpone the digging until it is reasonably certain that all or nearly all the eggs have hatched, lest eggs that are still incubating be disturbed.

"The search for the young terrapins can best be made by scraping the sand away with the hands, starting at one corner of the egg bed and pulling back the sand to a depth of 6 or 8 
inches. If unhatehed eggs are found they should be left undisturbed, but otherwise the entire bed should be carefully gone over. Later, toward winter, the beds may be dug over again, and early in the following spring search should be made for those which are certain to have been missed.

"Under natural conditions it is believed that the young terrapins do not feed from the time they hatch until the next spring, and if they grow during this period the growth is imperceptible. On the other hand, if hibernation is prevented and food is supplied the growth is steady, and by the following spring they have increased appreciably in size. Furthermore, the young ones which have been fed during their first winter appear to have secured a start which enables them to continue to grow more rapidly during the following summer, so that the lead they had in the spring over the young ones which had hibernated is increased, and by the time the end of the first year is reached they will average considerably larger. Whether feeding during the second and third winters is desirable appears doubtful, especially if several hundred of the young have to be cared for. The young terrapins, howerer, should in any event be kept apart from the adults for at least one full year and preferably longer. So far as is known, the adults do not intentionally injure the young ones, but in a crowded pen will doubtless kill their offspring by trampling over them and depriving them of food.

"The tanks in which the young terrapins are kept may be constructed of planks, or wooden or metal washtubs may be utilized. They should be water tight and, if there are rough surfaces or corners up which the terrapins might be able to climb, a projecting shelf should rum around the top to prevent escape. An average-sized tub or a tank 2 feet square will accommodate about 50 young terrapins, and the animals are more easily cared for and seem to do better if they are divided into lots of about that number.

"A little water, either fresh or salt, should be put into each tank and the tank then tilted, so that the water corers half the bottom with a depth of about an inch in the deepest part. A 1-inch hole with a plug at the lowest point will facilitate greatly the cleaning out of the tank. The tanks may be kept out of doors in some well-shaded place until the beginning of cool weather.

"Feeding should be begun as soon as the young ones are placed in the tanks. The food used may be finely chopped crabs or mineed fish, the latter being given by taking a chunk of fish and rubbing it in the hand in the water of the tank until a quantity of flesh has been rubbed off. Only a little food should be given at a time and care should be taken that remnants are not left to putrefy and foul the water.

"At first only a very few of the little terrapins will eat, but in a few days, perhaps with some coaxing, all or nearly all will learn to eat.

"If the young terrapins are to be allowed to hibernate, suitable quarters should be in readiness for them by the time cold weather sets in. A box 3 feet long, $1 \frac{1}{2}$ feet wide, and 12 inches 
deep, with top, bottom, and sides of galvanized wire netting, the cover being hinged, should be sunk in the ground in some place where the drainage is good so that its top is level with the surface. The bottom of the box should be filled with sand, and the terrapins placed about 5 inches below the surface. The place should not be disturbed until the following spring, unless there is reason to believe that something has gone wrong. At the beginning of warm weather the next season, about April 15 or May 1, the box should be opened up, the terrapins removed to the tanks, and as soon as they have become active should be placed in the special pen made to hold them. Thereafter they should be fed daily on finely chopped food.

"If it is decided to feed the young terrapins through the winter, some building must be available in which the temperature ean be maintained at about 70 or 80 degrees through the coldest weather. At Beaufort, when only a few young were handled in this manner, the engine house, near the laboratory, was utilized, but as the number of young ones increased it became necessary to provide a special building. This is constructed somewhat like a greenhouse, with the south slope of the roof, which is longer than the north slope, almost entirely of glass. The size is 25 feet 6 inches by 15 feet 4 inches. In this building about 2,000 young terrapins can be housed.

"In winter quarters the young terrapins which are not allowed to hibernate are to be fed and otherwise eared for exactly as if they were out of doors. If the temperature is kept at about $75^{\circ} \mathrm{F}$. they will show no desire to hibernate and will continue to feed. Beyond furnishing food and keeping up the heat supply the only care required is eleanliness. Decaying food must not be left in the tanks and the water should be changed once a day at least. In the spring the terrapins are put into out-of-door pens and are fed as the others are.

"Rate of Growth.

"Throughout the experimental work a careful record has been kept of the growth of all the young or selected lots of 100 or more of each season's hatch. When first hatched, the average length of the terrapin is about $1 \frac{1}{8}$ inches (28.21 millimeters), the smallest being a little less than an inch (24 millimeters) and the largest about $1 \frac{1}{4}$ inches long. In the few weeks of activity before hibernation takes place they grow very little and the next spring they average certainly no larger and probably slightly smaller than when they went into winter quarters.

"During their first summer, if properly cared for, they will add a little over an inch to this length and the next spring will emerge from hibernation a little over 2 inches long. During the second summer another addition of about an inch is made to their length and they will emerge from their third hibernation about 3 inches long. These measurements include both sexes.

"Up to the beginning of their third summer it is very rarely possible to distinguish the sexes with any degree of eertainty, but as the season progresses the differences become evident 
and the females begin to show increased growth. By the end of this season the females will average about $4 \frac{1}{4}$ inches long, while the males will average about $3 \frac{3}{4}$ inches long. During this summer, therefore, the males add on the average (assuming they were of average size to begin with) about three-fourths of an inch to their length, while the females add about $1 \frac{1}{4}$ inches.

"At Beaufort the experimental work stops at this point, as the oldest brood of terrapins hatched in the pound is only 3 years old. It seems probable, however, that the females will continue to grow at about the rate indicated until maturity is reached, and that a breeder of the animals might with some confidenee expect a few salable individuals among a large number at the end of four years, and a good many at the end of the fifth year. The males, as is well known, are of little value and should be gotten rid of as soon as they can be positively identified.

"The death rate among the young terrapins in the pounds at Beaufort has been very snall, averaging perhaps 4 or 5 per cent. They have, however, received the best of care and a beginner in the work should not expect so good a result until he has become accustomed to handling the animals.

"The proportion of males to females among the newly hatched young is not known. It is believed that males and females are present in about equal numbers, but in the small brood of 1909, the only one in which the sexes can be distinguished, there are 8 males and 4 females. Among the adult terrapins the males do not so greatly exceed the females, so the brood just mentioned can not be regarded as a fair sample."

Regarding the outlook for the terrapin industry, Coker states: "The terrapin has not the powcr to regain its hold within a few years, as the oyster or the clam might do. Each female lays but a few eggs and the young that hatch from them undergo many perils. Those that survive the dangers of early life are slow to reach the stage where they may start another generation, and before reaching this stage they may be captured and sold at a small price.

"The terrapin gets no opportunity to re-establish itself. Though they are now so scarce that it rarely pays to hunt them, yet the market value is such that no chance individual observed will be passed by. In the exhaustive search of our waters for clams, oysters, crabs, and fish, individuals are not infrequently found, and thus the work of extermination proceeds without check.

"Exhaustion of the fishery is inevitable, unless some legislative provision be made for its preservation.

"Only two methods of protection suggest themselves. The one is propagation; the other, effective restriction of the fishery."

There is no law in Massachusetts for the protection of this terrapin. 


\section{Clemmys guttata (Schneider). \\ Spotted Turtle; Mud Turtle. \\ Plate 27.}

Testudo guttata Schneider, Schr. Ges. Naturf. Freunde, Berlin, 1792, vol. 10, p. 264.

Clemmys guttata Strauch, Mém. Acad. Sci. St. Pétersbourg, 1862, ser. 7, vol, 5, no. 7, p. 107.

The Spotted Turtle, with perhaps the exception of the Painted Turtle (Chrysemys picta), is the commonest Chelonian in New England.

Size.- Measurements (in inches) of two adult specimens are: length of carapace (in straight line), male $4 \frac{1}{2}$ inches, female 4 inches; length across curve of carapace, male, $5 \frac{1}{4}$, female, $4 \frac{1}{2}$; width (in straight line), male, $3 \frac{1}{4}$, female 3 ; wilth on curve of carapace, male, $4 \frac{1}{4}$, female $4 \frac{1}{8}$; height of carapace, male, $1 \frac{1}{2}$, female, $1 \frac{1}{2}$; stemal length, male, $3 \frac{3}{4}$, female, $3 \frac{7}{8}$; sternal width, male, $2 \frac{3}{8}$, female $2 \frac{1}{2}$.

In the male the tail is more than twice the length of that of the female.

Color.- The carapace is black, covered irregularly with circular orange spots (specimens taken in salt marshes have a decidedly rusty appearance). The plastron is black blotehed with pale yellow. The head is black, with a large deep-orange spot over the aural region. The neck and extremities are "pale salmon," bordered with black.

Yerkes (1905), from a study of color patterns in this turtle, draws the following conclusions:

"1. The young of this species of tortoise usually have a single yellow spot on each plate of the carapace, except the marginals. With age the number of spots increases, they appear on the marginal plates also, and their arrangement becomes irregular.

"2. The epidermal layer is transparent immediately over the mass of yellow pigment in the outer bony layer, hence, window-like regions in the outer portion of the shell.

"3. Although the females are slightly smaller than the males they usually have about 15 per cent. more spots on the carapace. The average number for the males is 60 , for the females 69 . This would seem to indicate that the brightly colored spots serve as both sex and species marks. Probably they serve to render the females conspicuous.

"4. Statistics indicate a greater number of spots on the left side of the carapace than on the right in both males and females. It is possible that this is to be correlated with righthandedness and right-eyedness."

Agassiz (1857, vol. 1, p. 443) states that he has seen old specimens "entirely black." Where the spots occur but singly on each shield, they are usually larger than when appearing in groups. 
Description.- In this species the shell is somewhat flattened, with the edge of the carapace not serrated; the shields are smooth and the feet show a reduction in the degree of webbed formation as compared with our species of the genera Chelydra, Chrysemys, Malaclemys. The upper jaw is slightly notched in front, and the lower jaw is arched upward. There is a complete bony temporal arch. The legs are scaly. In the male the plastron is slightly concave (see measurements) and the tail is longer than in the female.

Geographic Distribution.-- This turtle ranges throughout the Atlantic States from Maine to northern Florida, extending westward to Ohio, Indiana, and Michigan.

New England Rccords. - The Spotted Turtle is reported as an inhabitant from all the New England States. In the collection of the Boston Society of Natural History are specimens from: (1) vicinity of Augusta, Maine; (2) Ipswich and (3) Riverside, Massachusetts.

Habitat.- It occurs in ponds and streams with muddy bottoms. I have frequently taken it in salt marshes. It not uncommonly travels about on land at considerable distances from water.

Numbers. - In Maine (about the northern limit of its distribution) this turtle is reported as rare (Verrill, 1863), but in the southern New England States it is very common. Storer (1S40) considers it the commonest turtle in Massachusetts, but Chrysemys picta probably holds that distinction. Drowne (1905) reports it "common in the Pawtucket River," (R. I.). Allen (1S68) says it is rarely found with Chrysemys pieta. It is not unusual, however, to take numerous specimens of each from a given limited area.

Brceding Habits. - In New England the laying season of this species practically coincides with that of Chrysemys picta, that is, from the 10 th to the 25 th of June. In captivity the process of laying may be delayed several months.

Two or three (rarely four) white, elliptical eggs (averaging $30 \times 17 \mathrm{~mm}$.) are deposited, the time of laying being in the late afternoon or evening. Copulation takes place in the water, the male grasping the female so tightly that it is passible to raise them both by lifting the former. Following this function the males appear very languid for several days.

Grouth.- Eggs of this turtle which I buried in sand on June 16 (1915) hatched on September 6, an incubation period of eighty-two days. The young showed a horny tubercle on the end of the snout and a single yellow dot on each shield. The rate of growth was:

\begin{tabular}{lc|cc} 
Age & Length of Carapace & Age & Length of Carapace \\
At birth (Sept. 6) & $26 \mathrm{~mm}$. & 2 month & $32 \mathrm{~mm}$. \\
1st month & $30 \mathrm{~mm}$. & 5 th month & $32 \mathrm{~mm}$.
\end{tabular}

The young were active as soon as hatched and were excellent climbers. On the tenth day they were fed angle worms and thereafter one worm on every second day. After November 3d (end of second month) nothing was eaten, which explains the cessation in growth. They did not survive the winter. 
The horny nasal tuberele (the function of which is to assist the animal in breaking through the egg-shell) disappeared in from seren to ten days. The stump of the cord was visible at the umbilicus for about a week.

Habits.- While this species is less aquatic in its habits than Chrysemys picta, it is usually seen along the water's edge, especially in clumps of water grass where it is fond of sunning itself.

"In fresh-water bogs it exhibits a seemingly social spirit. Certain miniature islands of bunch grass are matted down by clusters of turtles that go there regularly to bask and an old $\log$ may be so thickly covered that several turtles have been forced to roost on the shells of those having secured favorite spots. Thus the little colony takes a bath in the life-giving sun, with limbs sprawled out in comical fashion and ever-attentive eyes on the lookout for danger. Ludicrous results follow the approach of the human observer, as there is a panicky scramble for the water, a series of splashes, then a desolate log without sign of life" (Ditmars, 1910).

It is active in this region from Mareh until November. During the late summer and fall the males are less in evidence than the females. This turtle is hardy in captivity and seems less timid and wary than the more strictly aquatic forms. My specimens preferred to sleep out of water. They never snap.

Yerkes (1901) used this species in a study of the formation of habits in the turtle. The habit studied was the finding of the way through a labyrinth to a nest. He found that "the turtle profited by experience and that very rapidly," that there was remarkably little aimless wandering, and he believes that smell and sight are important elements in associative reactions of lower animals. His explanation is as follows: "The wandering impulse led by chance to the finding of satisfaction, the action was impressed on the vital mechanism, so that there was a tendency (the beginning of a habit) toward repetition of it. Had the action failed to give satisfaction, the probability of its being repeated would have been merely that of chance, and not chance plus the influence of the former pleasure-giving activity. The turtle happened to crawl over the edge of the incline, and, finding that this enabled it to get to the nest quicker, it continued the act, thus forming a habit."

Food Habits. - The Spotted Turtle feeds on insects, worms, larvae, small mollusks, tadpoles, etc., and in captivity will eat ehopped fish and occasionally vegetable matter. In examining the stomach contents of twenty-seven individuals of this species, Surface found: leaves, seeds, grass, worms, slugs, snails, erayfish, millipedes, spiders, dragon-flies, bugs, butterflies, moths, flies, beetles, saw-flies and other insects. Holbrook (1842, vol. 1, p. S3) states that "it takes to land frequently in search of food." I have never seen it eating, however, except while under water.

Enemies.-Burroughs ${ }^{1}$ remarks on the fearfulness of this turtle and eannot understand

${ }^{1}$ Burroughs, John. Squirrels and other fur-bearers, 1875, p. 138. 
it, as he knows of nothing that preys upon it. He says: "The little spotted water turtle is as shy as if he were the delicate tidbit that every creature was searching for.... I did once find one which a fox had dug out of the mud in winter, and carried a few rods and dropped on the snow, as if he had found he had no use for it." The eggs are sometimes dug up and eaten by skunks.

Economic Importance.- The Spotted Turtle has no commercial value. 


\section{Clemmys muhlenbergii (SсHоерғF). \\ MuHLenberG's Turthe. \\ Plate 28.}

T'estudo muhlenbergii Schoepff, Hist. Testud., 1S01, pt. 6, p. 132, pl. 31.

Clemmys mullenbergii Strauch, Mém. Acad. Sci. St. Pétersbourg, 1\$65, ser. 7, vol. 8, no. 13, p. 67.

This turtle was named in honor of Rev. Mr. Muhlenberg of Pennsylvania, an early American naturalist.

Size.- It is one of our smaller turtles. Measurements of an adult female from Nerport, R. I., in the collection of the Museum of Comparative Zoölogy at Cambridge, Mass., are: length of carapace, $3 \frac{1}{2}$ inches; width of carapace, $2 \frac{9}{16}$; length of plastron, $3 \frac{3}{16}$; width of plastron, 2; length of bridge, $\frac{7}{8}$ of an inch; width of head, $\frac{9}{16}$ of an inch; length of tail, $1 \frac{1}{16}$. A length of carapace of $4 \frac{1}{2}$ inches is occasionally attained.

Color.- The carapace is dull brown or black with faint yellowish (sometimes reddish) blotches which are centrally placed on each shield. These are not always present. Occasionally a specimen is found showing yellow spots as in C. guttata. The plastron is black, irregularly marked with yellow. The head is black, with a large bright orange spot back of each ear. The neck is brown and the extremities brownish yellow or dark brown.

Description.- The carapace is oblong, somewhat contracted and slightly keeled. The shields are sometimes smooth but usually concentrically grooved, although less deeply than in C. insculpta. The nuchal shield is very narrow. There are twenty-five marginals. The plastron is emarginate posteriorly. The head is short and broad; the eye large, with brown iris. The upper jaw is deeply notched and arched downward. The toes are less extensively webbed than in C. guttata. There are five claws anteriorly and four posteriorly.

Geographic Distribution.- This turtle has a restricted and local range. It occurs in eastern Pennsylvania, New Jersey, southern, central, and western New York, and has been taken at Newport, R. I.

New England Records.- There is but one record of this turtle for New England. In 1902, Alexander Agassiz took three specimens (two males and one female) at Newport, R. I., and presented them on September 23d, to the Museum of Comparative Zoölogy at Cambridge, Mass., where two of them now are. The third has since been given to the Boston Society of Natural History. As this species also oceurs in southern New York it would seem probable that the range extends through southern Connecticut as well, although there are as yet no published records. 
Numbers.- It is local in occurrence and nowhere very abundant, even rare, although rather generally distributed throughout New Jersey. Ditmars (1907) states that he has received several dozen specimens from Staten Island, New York.

Habilat.- This turtle often leaves the water, but is usually found in swampy localities near clear running streams.

Breeding Habits. - Muhlenberg's Turtle resembles C. guttata and C. insculpta in its breeding habits.

Habits. - This turtle has distinctly terrestrial habits although confining its wanderings to swampy locations. It is entirely at home, on the other hand, in water and rather more agile in the latter environment.

Food Habits.-- In its feeding habits this turtle exhibits one very interesting phenomenon: that of feeding with the head out of water. In the progress upward from the lower aquatic forms of Chelonians to the higher land-going types, this species is the milestone at which members of the order become able to swallow food without submerging the head, thus extending at once their feeding range.

Muhlenberg's Turtle is omnivorous. Surface (1908) found stomach contents of this species to contain berries and insects (undetermined fragments).

Enemies.- The eggs and young are destroyed by predaceous fish, birds, and mammals.

Economic Importance. - While this turtle is too small to have any food value commercially, it has a distinct part to play in the economy of Nature, as have all the other small fresh-water Cholonians. This rôle consists in the destruction of injurious insects, which constitute a part of its food, and in acting as a scavenger by feeding upon dead animal matter. 


\title{
Clemmys insculpta (LeConte).
}

\section{Wood Tortoise; Sculptured Tortoise.}

\author{
Plate 29.
}

Testudo insculpta LeConte, Ann. Lye. Nat. Hist. New York, 1830, vol. 3, p. 112.

Clemmys inseulptu Strauch, Mém. Acad. Sci. St. Pétershourg, 1862, scr. 7, vol. 5, no. 7, p. 104.

This is considered by Storer to be "our most beautiful tortoise."

Size.- Large specimens reach a length of carapace of slightly over eight inches, one in the collection of the Boston Society of Natural History having a curved length of $8_{8}^{5}$ inches. The shell of an adult specimen in my collection measures: length, in a straight line, $6 \frac{3}{*}$ inches; length along curve of carapace, $7 \frac{1}{8}$; width in a straight line, $4 \frac{7}{8}$; width along curve of carapace, $6 \frac{1}{4}$; hejight, $2 \frac{1}{2}$; sternal length, $6 \frac{3}{8}$; sternal width, $4 \frac{3}{8}$.

Color.- The carapace is dull brown, with irregular faint yellow markings. Young specimens sometimes show radiating narrow yellow lines on each shield. The plastron is yellow, and each shield contains a large black spot on its outer margin, as do also those of the inferior marginals of the carapace. The head and feet are blackish, the remaining soft parts, especially the neck, a vivid brick red.

Description.- The carapace of this species has a rough "sculptured" appearance, each shield containing a series of concentric ridges or grooves, rising one above the other in a pyramidlike manner, the center of each series being in the posterior portion. It is strongly keeled and serrated at the rear margin where it flares slightly upward. The plastron is heavy and deeply notched posteriorly. The feet are partially webbed, the hind toes more than the fore.

"The upper jaw projects in the form of a bill, arched downward, notched at the tip, and so compressed sidewise that the margin of the mouth is narrower than the top of the forehead orer the nose. The edge of the lower jaw is straight, except the tip, which is greatly arched upward. The horny sheath of the horizontal alveolar surface is narrow in both jaws. The margin of the sheath is very thin and spreading in the young, and the surface of the scales is coarsely granular. In the adult they have radiating ridges, which in very old age are sometimes entirely smoothed down" (Agassiz).

Parker (1901) in a study of correlated abnormalities in the scutes and bony plates of the carapace of the Sculptured Tortoise arrives at the conclusion that a close relation exists between the bony plates and scutes and that "in primitive turtles each bony plate was associated with a single scute." In the carapace of Clemmys insculpta there are fifty bony plates and thirtyeight scutes or shields. Young specimens appear especially rough. In the males the tail is longer, the scales on the front legs coarser, and the claws heavier than in the females. 
Geographic Distribution.- This species is essentially a boreal one, ranging northward into Canada and south through New Jersey and Pennsylvania to the Maryland shore of the Potomac, "near Plummers Island, about ten miles west of Washington, D. C.," which southernmost record was established in 1907 by H. WV. Henshaw (1907). Westward it ranges to Ohio, Michigan, Wisconsin, and southwestern Ontario.

New England Records. - This species is recorded from all of the New England States. In the collection of the Boston Society of Natural History are specimens from Augusta, Maine; Littleton and Concord, New Hampshire; and Ipswich River, Massachusetts.

Numbers.- This turtle appears to vary greatly in abundance in different localities. It is reported as common in Oxford County, Maine (Verrill, 1863); common in the vicinity of Springfield, Massachusetts (Allen, 1868); very common about Lancaster, Massachusetts (Agassiz); and rare in Rhode Island (Drowne, 1905). I have not found it common in the region about Dedham, Massachusetts. Agassiz (1857, vol. 1, p. 294) in speaking of its occurrence in Lancaster, Massachusetts, says it "is so common in the neighborhood...that I have at times collected over one hundred specimens in an afternoon, aided by a few friends." Numbers are doubtless burned in the woods during the periods of forest fires.

Habitat.- The Wood Tortoise occupies a position on the border line between aquatic turtles and terrapins and land-going tortoises, ranging far from water during the summer and leading during this time a strictly terrestrial existence in woods and pastures, but returning in the fall to swampy regions and hibernating during the winter in the mud of river and pond bottoms, or sometimes on land in the woods. In the spring it is often seen in the water. Next to the Box Tortoise (Terrapene carolina) this is our most terrestrial Chelonian.

Breeding Habits. - The laying season of the Wood Tortoise corresponds with that of our other New England turtles (roughly, June 10 to June 25). Thoreau (1884, p. 160) speaks of finding one laying in mid-afternoon, and refers to June 12,1860 (with the temperature at $85^{\circ}$ F. at 2 P. M.) as the date when turtles "fairly and generally began to lay" for that year. During the mating season both sexes have been observed to utter a subdued whistle. The eggs, as with other species, are deposited in a cavity in the ground prepared by the female, then covered and left to be hatched by the heat of the sun. The eggs are ellipsoidal in shape and are thin-shelled. A. H. Wright makes the following interesting observation: "In the fall of the year we find these turtles, from September 20-October 15. [New York.] Then, as in the spring, they are near or actually in our streams. This fall on October 1 , I chanced on what I mistook for a dead wood turtle in the dammed-up stretch of a woodland stream, which was 4 feet wide and 1 or 2 feet deep. The head was hanging perpendicularly downward as if it were caught or held by something. Upon endeavor to move it the turtle seemed very heavy, and soon to my surprise it proved the male of a mated pair. The head looked to be hooked between the edge of the carapace and plastron of the female turtle. Apparently this was not for 
purposes of holding the female, but like the action of the whistling male previously recorded. The female's head looked to be retracted and the male's head had followed to the withdrawu head of the female. After these turtles were taken from the water the writer could not verify the actual head relations nor see the actual cloacal contact. For several minutes the male however maintained its grasp. With the prominent fore-claws the male held on the edge of the female's carapace near the suture between the first and second cephalic plates. The space between these two feet was barely the width of the male's head. The hind claws similarly held the next to the last pair of caudal marginals."

Young.- It is unusual to find very young specimens of either this species or the Box Tortoise (Terrapene carolina). It is believed that they remain very closely under cover until well grown. In this connection Agassiz states that although he had received hundreds of adults he had never been able to obtain a single young specimen of the first year. Thoreau speaks of finding one young specimen $1 \frac{1}{2}$ inches long, with no orange, only buff or leather color on the sides. At birth the length of carapace is 30 to $32 \mathrm{~mm}$.

Habits.- The striking fact in the behavior of this turtle is that it combines an aquatic with a terrestrial existence, being in a state of transition from a lower to a higher plane of life (see Habitat). It travels well on land, yet is an excellent swimmer. One of my specimens which had lived four years in an aquarium, adopted completely terrestrial habits without difficulty. Speaking of its tenacity of life, Linsley (1844) says: "Mr. S. Crofut of Derby assured me that he once laid one of these tortoises on its back upon a rock, and laid a stone on it to retain it in that posture, and three weeks after he found it in that situation as he left it, but apparently as lively and well as ever. He then turned it over and put on the stone again; and after a great length of time had elapsed, having forgotten it, he found it as well as ever, and then released it.... It evinces a wonderful capacity of the animal to sustain life under these very trying circumstances."

Huse (1901, p. 49) relates the following: "A specimen that I kept for a portion of two seasons ate nothing for a while but was brought to his appetite by ripe strawberries. After that he would eat almost any soft vegetable food. Placed in a pen with some rabbits, he repeated the old fable in a revised form by climbing the poultry netting that served as a fence and escaping while his long-legged compauions stayed behind."

Shufeldt (1916) in describing the actions of a pair kept in captivity says that the male killed the female by biting her until she died from loss of blood. He states thac the male was affectionate, coming to rest on one of his feet as he sat writing at his study table. Ierkes (see Box Tortoise) found that certain behavior reactions in this species more nearly approached those of the land-going Box Tortoise than did those of either the Spotted (Clemmys guttata) or Painted (Chrysemys picta) Turtles. As a rule the Wood Tortoise is not vicious, but will snap occasionally. 
Food Habits.- This Chelonian is omnivorous, although showing a distinet partiality for vegetable food, especially berries (strawberries, blackberries, and blueberries) during warm weather while living on land. It has been observed to feed on various kinds of vegetation, such as leaves, scapes of dandelion (Taraxacum denslconis), fruit of the low field blackberry, sorrel, leaves of early potentillas; also insects, and insect larvae. Thoreau found the paunch of one specimen to contain "much vegetable matter, old cranberry leaves, etc." Surface found the stomach contents of twenty-six individuals of this species to include: mushrooms, moss, grass, seeds of blackberry, strawberry, and apple, clover, black alder seeds, fox grapes, nightshade berries, turtle-head seeds, plantain, partridge berries, elderberries, earthworms, slugs, snails, crayfish, millipedes, insects, bugs, moths, flies, beetles, saw-flies, ants, and fragments of birds. A captive of mine ate nine strawberries at one meal. These were held with the fore feet, while being bitten and torn apart. The same is done with small fish (horn-pout) after they have been killed by biting the head. The turtle apparently cannot see directly ahead, for it always arches its neck and turns its head to one side before striking at food placed in front of it. Shufeldt describes the actions of one of his captive individuals in begging for food. He says it stood on three legs and waved the fourth, or walked around in a circle a yard or so in diameter. This turtle is easily tamed and will take food from one's fingers. As cold weather approaches it refuses food and if not provided with a suitable environment for hibernation, will not survive the winter months.

Enemies.-Thoreau once found a Sculptured Tortoise on its back, while a hawk or crow was making rapidly off. There were tracks all about and the turtle's extremities were drawn closely in. He thinks the turtle was being picked at. He has also observed a skunk robbing a nest. A young Wood Tortoise about two inches in length was taken from the stomach of a large-mouthed black bass (Surface). This species is sometimes infested with a leech (Clepsine scabra).

Economic Importance.- The flesh of this turtle is edible and in some districts considerable numbers of these animals are collected to be sold for food. New York State has found it necessary to pass a law for their protection. 


\section{Emys blandingii (НоцвRоок). \\ Blanding's Tortoise; Semi-box Turtle; Speckled Tortoise.}

Plate 30.

Cistudo blandingii Holbrook, North Amer. Herp., 1838, ed. 1, vol. 3, p. 35, pl. 5.

Emy.s blandingii Strauch, Mém. Acarl. Sci. St. Pétersbourg, 1862, ser. 7, vol. 5, no. 7, p. 29.

Blanding's Tortoise is the only representative of its genus in the Western Hemisphere. It was named for Dr. William Blanding of Philadelphia, who first observed it.

Size.- The measurements of an adult specimen in the collection of the Boston Society of Natural History are: length of carapace in a straight line, $6 \frac{1}{2}$ inches; length following curve of same, $7 \frac{5}{8}$; width in straight line, $4 \frac{1}{2}$; width following curve of carapace, $7 \frac{1}{8}$; height, $2 \frac{3}{4}$; sternal length, $6 \frac{5}{8}$; sternal width, $3 \frac{5}{8}$.

Color. - The carapace is dull black with many small pale yellowish spots. The plastron is pale yellow with a large blotch on the outer and posterior portion of each shield. The head is dark brown or black, dotted with yellow, while the chin and throat are a very bright yellow. The young are entirely black above, while the plastron is black with a light edge.

Description.- - Important characteristics of the anatomy of this turtle are the ligamentous union of the carapace and plastron, narrow horizontal alveolar surface, the narrow bony sheath of the bill which is notched in front, the alveolar edge rising gradually to form a triangular emargination, while under the eye it is arched down. The plastron is divided across the middle by a slightly flexible ligamentous hinge between the hyo- and hypo-plastral plates and the pectoral and abdominal shields. The anterior half is more movable than the posterior. The plastron is large but does not entirely close the box as it does in the Box Tortoise. The carapace is high and globular, somewhat elongated. There are a small nuchal and twelve pairs of marginal shields. The head is cylindrical in shape, covered with smooth skin, and the neck is long. The temporal arch is complete. The feet are webbed. Young specimens are nearly circular.

Holbrook (1842, vol. 1, p. 39) was the first to recognize this species. His description of a specimen from Fox River, Illinois, is here given:

"Description. The head is rather small, smooth above, and slightly pointed at the snout; the nostrils are anterior, and closely approximated; the eyes are large and prominent, the pupil black, the iris light grey. The upper jaw is broad, the cutting edge sharp and deeply emarginate in front; the lower is strong and firm, and furnished with a small hook. The neck is long and slightly contracted at the back of the head. 
"The shell is oblong, rounded, very nearly as broad before as behind, smooth and ecarinate, with an entire margin. Of the vertebral plates, the anterior is broad, pentagonal, with two of its articulating surfaces directed forwards and outwards, and meeting at an angle in front; the second and third are very regularly hexagonal, broadest in the transverse direction - the former very slightly concave in front, and the latter as slightly concave behind; the fourth is regularly heptagonal, rather concave posteriorly; the fifth is octagonal, smaller above and larger below. The anterior lateral plate is irregularly quadrilateral, larger and rounded below, smaller and straight above; the second and third are pentagonal; the fourth is smaller and quadrilateral. There are twenty-five marginal plates, making an entire cutting border; the intermediate or nuchal is of moderate size and nearly a parallelogram, being only slightly notched on its posterior margin to receive the point of the first vertebral plate; the first marginal plate is regularly quadrilateral, the second pentagonal, the third and fourth quadilateral, the fifth pentagonal, the sixth quadrilateral, the seventh pentagonal, the eighth quadrilateral, the ninth pentagonal, the tenth quadrilateral, the eleventh pentagonal, and the twelfth quadrilateral; these forms are constant. All these plates are smooth in the centre, and but indistinctly marked with concentric striae near their borders.

"The sternum is oblong, full, and rounded in front, deeply emarginate behind, and composed of two valves, of which the posterior is rather the larger. These valves are united to each other and to the sternum by ligamento-elastic tissue, so that both sections are movable on the same axis. The gular plates are very regularly triangular, with their apices backwards; the brachial are elongated, quadrilateral, rounded and broader externally, straight and narrower within. The thoracic and abdominal plates are regularly quadrilateral, and of nearly the same size. The femoral are similar in form to the brachial plates, and the sub-caudal are rhomboidal. All these plates are marked with concentric striae.

"The anterior extremities are strong, rounded, and covered with imbricated scales in front, and with smaller scales and granulations behind; the fingers are five, slightly palmated, and furnished each with a short curved nail. The posterior extremities are round above, flattened at the leg and tarsus, and covered in front and behind with small scales and granulations; the toes are five in number, semi-palmated, the four internal are furnished with short curved nails. The tail is long, thick at the root, but soon becomes cylindrical and snall."

Geographic Distribution.-- "Blanding's Turtle appears to attain a centre of abundance in Indiana, thence it occurs in lesser numbers in Illinois, Wisconsin, Michigan, Ohio and on the north shores of the Great Lakes in Canada. Eastward of the Central States it is a comparatively rare species, though the range extends into the Alleghanean region and northeastward through Pennsylvania and New York, into Massachusetts, Rhode Island and New Hampshire. The species does not occur near the coast regions of New York, Connecticut or New Jersey" (Ditmars, 1907, p. 56). 
It is of interest to note that the only other species of this genus (which closely resembles E. blandingii) occurs in southern and central Europe, Asia Minor, and northern Africa, although its range formerly extended through Germany, the Netherlands, and Denmark, into southern Sweden and the British Isles. The widely separated areas of distribution of these two very similar turtles is explained by the "land-bridges" which formerly connected North America with Europe and with Asia. Scott ${ }^{1}$ says in this connection: "Between Europe and North America there has always been a certain proportion of mammalian forms in common, a proportion that was at one time greater, at another less, and this community renders the correlation of the larger divisions of the Tertiary in the two continents comparatively easy, and even in the minor subdivisions very satisfactory progress has been made, so that it is possible to trace in some detail the migrations of mammals from the eastern to the western hemisphere and vice versa. Such intermigrations were made possible by the land-bridges connecting America with Europe across the Atlantic, perhaps on the line of Greenland and Iceland, and with Asia where now is Bering Strait. These connections were repeatedly made and repeatedly broken during the Mesozoic and Cenozoic eras down to the latest epoch, the Pleistocene."

New England Records.-- While this turtle is nowhere common in New England, it is recorded from Manchester (near Cohas Brook), Milford, and Auburn, New Hampshire; from Haverhill, Lancaster, Concord (and also from Concord River, off Dakin's Hill, Concord) (Howe, 1911), North Reading, Tyngsborough, and Billerica, Massachusetts. Drowne states that it is "recorded in Rhode Island" but does not give any definite records. Linsiey says there is no absolute Connecticut record, but thinks he saw one. There is a single record from Long Island, at Queens (Schoonhoven, 1911). In the collection of the Boston Society of Natural History are specimens from Billerica, Mass.; Tyngsborough, Mass.; and Concord, Mass. This last specimen (a shell only) is of special interest, as it was collected and presenter to the Society by Henry David Thoreau.

Habitat.- This species is semi-aquatic. While it is sometimes found wandering about in fields and woods, it is usually seen in the vicinity of ponds and streams. Garman (1892, p. 215) calls it "essentially a terrestrial species." Individuals vary greatly in regard to their modes of life, some being almost wholly aquatic.

Numbers.- Blanding's Turtle is rare in New England, although reported as abundant in Indiana and other Central States.

Breeding Habits. - Gadow (1901, p. 355) describes the breeding habits of the closely allied species, E. orbicularis, as follows: "During the pairing season, on warm spring nights, they emit short piping sounds, and when they have foumd each other, the couple swim about together. The white, hard-shelled, long, oval eggs, averaging 25 to $15 \mathrm{~mm}$., and about ten in number, are laid on land. This is a very laborious and curious business. The female having selected 
a suitable spot, not loose sand, but rather hard soil free from grass and other dense vegetation, prepares the ground by moistening it from the bladder, and the anal water-sacs. Then it stiffens the tail and bores a hole with it, moving the tail but not the body. The hind-limbs then scoop out the hole, the broad feet moving alternately and heaping up the soil on the side, until the hole is about five inches deep, that is as far as the hind legs will reach. The eggs are laid at the bottom in one layer, divided and distributed by the feet. Lastly, the soil is put in again, and the tortoise, by repeatedly raising its body and falling down, stamps the soil firm and flat, roughens the surface a little with its claws, and leaves the nest to its fate. Nothing but an accident leads to its discovery. The young are hatched, according to locality and the kind of season, either in the same autumn or not until the next spring."

The eggs of the Blanding's Turtle arerage $36 \mathrm{~mm}$. in length and $24 \mathrm{~mm}$. in diameter.

Habits. - This turtle is very timid. "No amount of thumping will cause it to open the hinged plastron" (Morse, 1904). Yerkes (sce Box Tortoise) in studying it in reference to certain spatial reactions, places it in the same class with Clemmys guttata, which, he says, "it very closely resembles in behavior." A peculiar custom prevails among certain farmers regarding the E. orbicularis in Europe. They are said to keep a turtle in the water-troughs of their cattle in order to keep the water free from worms and other impurities.

Food Habits.- Regarding their habits of feeding, Ditmars (1907, p. 57) says: "Although fully as agile in the water - in swimming, diving and remaining a considerable time beneath the surface - as the typical pond and river turtles and terrapin, this species often evinces a desire to wander about on land, and while it seldom ventures from wet, marshy areas, prowls about through the undergrowth in search of tender shoots, berries and insect larvae, a character quite in opposition to the feeding habits of the strictly aquatic turtles and terrapins, which are unable to feed unless under water. Blanding's Turtle feeds with equal readiness upon the ground, or under water. Captive specimens are very fond of lettuce; they also feed voraciously upon earthworms, small fishes, tadpoles and young frogs, actively pursuing these creatures in the water and seizing them by a sudden dart of the head. Well fattened specimens are unable to employ the hinged plastron to but a slight extent and with such individuals the rear lobe is quite useless in covering the hind limbs which bulge from the shell in helpless fashion."

Enemies.- The eggs and young are exposed to danger from predaceous mammals, birds, and fish.

Economic Importance.- Blanding's Turtle has practically no commercial value, although occasionally it is used for food. 
Terrapene carolina (LiNNÊ).

Box Tortoise.

Plate 31.

Testudo carolina Linné, Syst. Nat., ed. 10, 175S, vol. 1, p. $19 \mathrm{~S}$.

Terrapene carolina Bell, Zool. Journ., 1825, vol. 2, p. 309.

Of all New England Chelonia, the Box Tortoise most closely approaches the Testudinidae or true land tortoises.

Size.- The following measurements are of an adult male in the collection of the Boston Society of Natural History: length of carapace (in straight line), $5 \frac{5}{8}$ inches; length following curve of carapace, $7 \frac{1}{2}$; width in a straight line, $4 \frac{5}{5}$; width following curve of carapace, $7 \frac{1}{2}$; height, $2 \frac{7}{8}$; stemal length, $5 \frac{7}{8}$; sternal width, $3 \frac{1}{4}$; length of anterior portion of plastron, $2 \frac{3}{8}$; length of posterior portion of plastron, $3 \frac{1}{2}$; width of head, $1 \frac{1}{8}$; length of tail, $\frac{7}{8}$ of an inch.

Color.- The markings and coloration are extremely variable. The carapace is usually dark brown or black with numerous irregular yellow, orange, or even reddish spots, blotches, or stripes. The plastron is brown or black with yellow patches of varying sizes symmetrically placed. The soft parts also vary in color and markings from dull flesh color to bright orange (especially on the neck). The eyes of the males are reddish and those of the females are light brown.

Description.- This species well illustrates the ability of Nature to specialize in a given direction, in that the plastron has lost its bony attachment with the carapace, being held by a ligamentous hinge on both sides, and is divided into two movable lobes united by a transverse hinge so perfect that the shell can be completely closed after the extremities have been withdrawn. ${ }^{1}$ In the male the plastron is slightly concave, in the female it is flat. Regarding variations in the Box Tortoise, Surface says: "In a series of forty-two specimens, seventeen males and twenty-five females, the following differences were observed. All males had a marked concavity in the posterior half of the plastron, in fact, the two sexes were separated using this character as a basis, and the accuracy of this division was subsequently confirmed by dissections. The carapace of the male has more or less of a flare at the posterior corners. The nuchal or neck notch is not quite so well marked in the females. The plastron of the females is very convex. The relation of both height and width is greater in the females. In the males the carapace is usually somewhat flattened. In other words, the carapace of the female approaches more nearly a spherical shape than does that of the male.

\footnotetext{
${ }^{2}$ In Cinyxis, an Old World genus, another unique modification occurs in the carapace, which is hinged, and its posterior portion movable.
} 
"Striations on the shell appear to be more marked in the young than in the old. Of course, the very young show none. Up to a certain size the ridges increased in size and number. After that it would appear that they become shallower or wear away and finally disappear."

The carapace is high and arched, sometimes showing rugosities, slightly oblong, or sometimes nearly round. There is a blunt keel. In young specimens the dorsal shields show well defined concentric rings. Posteriorly the carapace flares outward and slightly upward. The nuchal shield is very small and there are twelve pairs of marginals.

The head is covered with smooth skin. The skull is without a bony temporal arch, the quadrato-jugal and the jugal bones being absent. The horizontal alveolar edge is narrow; the hooked beak of the upper jaw projects downward, with or without a central notch; the lower jaw is sharply pointed in front. The hind feet are plantigrade. The digits, especially on the hind feet, show distinct though slight webbing suggesting that this genus is still in a transition stage between the aquatic and the terrestrial types. There are four toes on the hind foot, all provided with long sharp claws. The tail is very short.

Geographic Distribution.- Eastern United States, south to the Carolinas, Georgia, Tennessee, and Kentucky, reaching the Mississippi; west to eastern Illinois and Wisconsin, and north into Canada to the St. Lawrence and the Great Lakes (Taylor, 1895).

New England Records. - This species occurs in all of the New England States. In the collection of the Boston Society of Natural History are specimens from Falmouth, Mass.; Fall River, Mass.; Medway, Mass.; and a young specimen from Duxbury, Mass.

Individual Range and Age.- The individual range is probably very limited. Allen (1868) mentions a specimen found by a man within a quarter of a mile of the spot where it had been marked by his father sixty years before. Another bit of evidence is the many local color variations. The above record of Allen is suggestive as to the age which these reptiles attain. Deductions based upon dates previously cut into shells of specimens captured are not always reliable. Schenck (1886) records a Terrapene carolina known to have lived over sixty years. Gadow (1901) says of one he kept alive: "One of my specimens, certainly a very old one to judge from his hooked beak, perfectly smooth and flat shell, and from the condition of the marginals, which have the edges rubbed down quite smooth and rounded off, has two initials and the date of 1837 on its plastron. Of course there is no proof that the date had been cut in that year, more than sixty-three years ago, but it was done a long time ago. The scars on those parts of the shell which touch the ground are almost effaced, and the letters and figures have become somewhat distorted owing to the usual unequal, not concentrical, peripheral growth. Moreover, this tortoise must have been already adult, although not quite fully grown, since the marks are large and were evidently put in such a size and position as to fit the available space. I may mention that this record tortoise was, when I got it, not kept in confinement, but had been picked up at large." 
Ditmars (1907, p. 61) makes an interesting note in this connection: "A curious and interesting specimen was found several years from the time of writing, in Virginia. The writer had been roaming over the beautiful farmlands that once constituted the battlefields of Bull Run and Groveton. He had stopped to examine a noble tree, gnarled in many places from the old wounds of a heavy shell-fire. The tree stood on a knoll near Groveton and had been in the centre of a shower of lead and iron hail during the stormy days of war. On two occasions had the opposing armies swept over this pretty country to the tune of cannon and musketry and many trees beside the one that had particularly engaged the writer's attention, showed battle scars.

"These few descriptive words are in strict accordance with a turtle that drew the writer's attention, as it emitted a sudden hiss and closed its shell tightly at his approach. It was a very old specimen, with a dull, lustreless shell. Across its back was a deep furrow, healed by many years. So deeply did this penetrate into the creature's shell that the original injury must have penetrated to the very edge of the reptile's vitals, yet a wonderful tenacity of life and great reconstructive power had permitted the turtle to so heal the wound as to partially cover the deep tear with a rough, bony growth. Along the edges of the shell were other indentations, which had healed in the same manner. Who can dispute the very plausible theory, that nearly forty years before, during a human exchange of metal animosities, this reptile was struck by a flying minie ball that tore the furrow and, by the force of its impact, sent the creature tumbling over the stony ground to produce the deep scars about the edge of the shell. If such were the case, the reptile being full-grown when the injury was inflicted - the severe nature of the wound would stunt all subsequent growth - it had lived many years to attain its size, then possessed the tenacity to recover from the wound and afterward continued to live for nearly forty years after. It may interest the reader to know that this turtle is, at the time of writing, [1907], thriving in captivity."

Numbers. - This turtle is not generally abundant throughout New England. Storer says it is "pretty widely distributed" throughout Massachusetts. In certain portions of Plymouth County it is really common. Drowne says it is "uncommon in Rhode Island," and Huse remarks that he has seen but one New Hampshire specimen (at Pelham). It is reported as most abundant in New Jersey.

Habitat.- It is mainly terrestrial, inhabiting dry woods and bushy pastures. It has been known to ascend to a height of several thousand feet in mountainous country, as high probably as any other of our Chelonians (Taylor).

Breeding Habits.- The eggs of the Box Tortoise are often found in cultivated fields buried in the soft earth during June and July. In shape they are oval, possessing a thin and brittle shell. They measure (average) $35 \times 20 \mathrm{~mm}$.

Rosenberger (1916), observing the breeding habits of captive animals, states that the 
number of eggs laid varies from three to eight; that he saw eight eggs laid within half an hour; that a southern exposure was usually chosen for the nest; that the hole was about three inches deep and two inches wide, being dug very slowly (over a period of six to fourteen hours) with the hind legs; that the eggs were deposited either during the day or night (but chiefly the former); that each egg was adjusted and covered separately by the hind foot; that the nest was smoothed over with the body; and that the incubation period was about three months. (These observations were made at Philadelphia, Pa.) He also states that the mating season begins as soon as the period of hibernation is ended (April), the males maltreating the females and other males. "They [males] raise themselves as high as possible and lunge, bite, and snap." There seems to be a season of fall mating as well as spring mating. Very young specimens are rarely found in their wild state.

Habits.- Many naturalists have considered the Box Tortoise strictly terrestrial in its habits. This is true in the main, as the reptile spends much of the time during its active season in wandering about in dry woods and pastures. Young animals, however, are more aquatic in their habits than adults. Its movements are slow and deliberate like those of the true land tortoises. John Burroughs remarks that it shows "scarcely a trace of fear." When first picked up, however, it closes its shell tightly and remains in that condition sometimes for an hour or more. It is especially active during and immediately after warm rains. Recently several notes on the aquatic habits of this turtle have been published. Overton (1916) has seen specimens swimming in the water (on Long Island) or "resting in the shallows with only the head protruding above the surface." He says that when alarmed they often leave the land and enter the water voluntarily, and for ease and rapidity of swimming they compare favorably with Chrysemys picta. Culver (1915) thus describes the actions of a Box Tortoise which he saw swimming in Darby Creek near Addingham, Pennsylvania: "It swam very slowly and laboriously, only the highest part of the carapace and the head, from just below the eyes, projecting above the surface of the water. As it moved along, it bobbed up and down. After much effort, when within a few feet of landing on the opposite shore, it stopped to rest a second or so, floating a short distance down stream, when it resumed its movements towards the bank. Close to the bank it stopped paddling, floated gently up on the mud, and after a few moments' rest, crawled slowly out on the muddy shore, stopping again for a rest. Five or ten minutes later it was still resting in the sun." The distance covered was fifteen or twenty yards. Engelhardt (1916) in writing of the burrowing habits of the Box Tortoise says that this species, during hot summer weather has periods of aestivation. During such times he has found specimens buried to a depth of from six to ten inches in mud bordering a pool. He thinks they stay for weeks, since the entrance holes of the burrows were almost closed through sagging, followed by drying of the mud; and the turtles could not escape from these burrows except by breaking the crust of mud. Latham (1916) mrites in this connection: "One quite remarkable 
occurrence was in August, 1909, at East Marion [Long Island, N. Y.]. In the center of a dry woods there was a depression where the water had recently evaporated, leaving a deep oozy mire. In and around this sink I counted between sixty and seventy of these turtles. More than half of these were partly or entirely submerged in the mud. Specimens were poked out that were buried near a foot in depth. Circling around the hole at varying distances I observed numbers of others working toward it from all directions. The most surprising thing to me was the speed that the more distant ones were traveling. It may not be an uncommon fact that the Box Tortoise hurry, but was new to me, for these outsiders were moving on at the gait of a fast walk. This was a gathering of tortoises that I have never witnessed before or since.

"Cistudo also frequently enters salt water near Orient. Lying between a sandy cedargrown beach and the mainland of Orient is a bay one mile wide. I have on several occasions found these turtles midway across, always swimming leisurely toward the mainland. It seems evident that they enter the water of their own free will, as the beach to the south is flat and no creeks ruuning out.

"While off on the fishing ledges on the sound I have on two occasions seen this species more than half a mile from land. Although both these specimens were swimming toward the Orient hills to the south, they were being carried rapidly east or west with the strongly flowing tide. It is a question where these specimens came from, whether from the nearest inlet fifteen miles west, or the New England rivers. It is improbable that they entered the water near Orient." The same writer (1917) thus describes the actions of a captured specimen on another occasion: "Placing the animal on the sand in a small clearing, I reclined under a shrub oak to study procedure. Shortly the splendid head and neck were erected and held in a steady gaze. Presently a rustling was heard among the dry leaves to one side, which gradually drew nearer. Finally the upstretched neck and shell of a smaller male box turtle appeared in riew at the margin of the clearing 12 feet from the powerful specimen, which had remained absolutely motionless, but staring intensely at the new arrival. The small one advanced 4 feet, then paused, then another 4 feet venture and another pause. At the last pause, which was 4 feet from the first individual, the big fellow suddenly rushed at the new-comer with open mouth and grabbed it by the nape with such force as to roll it over on the side. It held the head to the ground for about 2 minutes, while the victim struggled unsuccessfully to draw its head within the shell. Releasing its hold, it actually chmbed over the conquered foe and walked rapidly away. It had traveled 10 feet when the small one hurried directly after it. The leader paused every few feet in the usual manner, but the other continued without halting till it was 2 feet in the rear. Thereafter it was very alert and copied perfectly every start and pause of the leader, which, evidently, was in ignorance of its shadower. I watched this interesting bit of wild life for 60 feet, when the head animal disappeared into thick corer, learing 
the rear tortoise gazing ahead in a puzzled, undecided quandary. It finally turned and came directly by the writer, while passing about 3 feet to one side. I talked loudly, whistled and sought to arrest its attention by mouth, while remaining perfectly motionless, but without success. However, the slight raising of one arm caused the head to be drawn suddenly into the shell with alarm."

As cold weather approaches this turtle prepares to hibernate by slowly and gradually burrowing into the soft ground for a depth of from three inches to two feet. It has been observed in an active state, however, as late as December 21, by J. T. Nichols at Englewood, N. J. (Copeia, Feb. 14, 1914, no. 3, p. [4]).

Many individuals leave their winter quarters too early and perish from exposure.

In captivity the Box Tortoise soon becomes tame. I have given specimens the freedom of the house and never knew one to snap. As cold weather comes on they refuse to eat, but remain inside of round balls of hay which they construct for nests. If not allowed to hibernate they often die during the winter months.

Yerkes (1904) has used this species (also Chrysemys picta and Clemmys guttata) in a study of the question: "What relation do the reactions of tortoises to space bear to their habits?" He describes his method of procedure as follows: "My method of experimentation was to place a tortoise in the middle of a board $30 \mathrm{~cm}$. by $60 \mathrm{~cm}$. which was elevated $30 \mathrm{~cm}$., $90 \mathrm{~cm}$. or $180 \mathrm{~cm}$. above a net of black cloth into which the animal fell when it crawled or plunged over the edge of the board. The fall was thus rendered harmless to the animals, and they gave no evidence, but increased hesitancy in crawling off, that it was disagreeable to them. The observer carefully noted the behavior of the tortoise while it was on the board, and recorded the time that it remained there. It would seem that the time from the noticing of the edge of the board till the fall should be recorded rather than the total time spent on the board, but as it was found that some species notice the spatial conditions while they are still in the middle of the board, whereas others give no evidence of perception of the height until they have reached the edge, it was necessary to make the record as described. Since in these experiments it was necessary that time as well as space should be considered, sixty minutes was fixed as the duration of the experiment, and in case the animal remained on the board longer than that period the test was recorded as a failure. Failures in this case have positive value, to be sure, but they do not give us the accurate measurement of the time of reaction which indefinite prolongation of the period of observation would furnish. ..." 
TABLE I.

Reactions to Spatial Conditions of Tortoises of Different Habits. Summary of Results

\begin{tabular}{|c|c|c|c|c|c|c|}
\hline \multirow[b]{2}{*}{ Height } & \multicolumn{2}{|c|}{ Chrysemys pieta } & \multicolumn{2}{|c|}{ Nanemys guttata } & \multicolumn{2}{|c|}{ Terrapene carolina } \\
\hline & $\begin{array}{l}\text { Average } \\
\text { Time }\end{array}$ & Failures & $\begin{array}{c}\text { Average } \\
\text { Time }\end{array}$ & Failures & $\begin{array}{c}\text { Average } \\
\text { Time }\end{array}$ & Failures \\
\hline $30 \mathrm{~cm}$. & $0.57^{\prime}$ & 0 & $27.6^{\prime}$ & 11 & $42.7^{\prime}$ & 9 \\
\hline $90 \mathrm{~cm}$ & $6.30^{\prime}$ & 0 & $19.1^{\prime}$ & 30 & $54.2^{\prime}$ & 33 \\
\hline $180 \mathrm{~cm}$. & $10.10^{\prime}$ & 1 & $60.0^{\prime}$ & 40 & $59.2^{\prime}$ & 39 \\
\hline
\end{tabular}

"This quantitative expression of the amount of hesitation exhibited by different species of tortoises under the same spatial conditions clearly indicates a close relation between the demands of the natural environment of the species, so far as spatial relations are concerned, and the behavior of the animals. A land tortoise has cause to notice heights and to react to them in a manner different from that of a water form. The former plunges over a precipice and is dashed to pieces, the latter plunges into the water from an equal height without injury. It is interesting to note, too, that there are intermediate forms between the two extremes, for the 'spotted' tortoise $N$. guttata is more careful in its reactions to space than $C$. picta, but less so than T. carolina."

He comments on the behavior of the separate species as follows: " $C$. picta when blindfolded usually rushed off a surface at any height without the least hesitation. There is no evidence, from my experiments, that the tactual and muscular impressions received when the legs. are stretched over the edge have any inhibitory influence on the movement. From this it is clear that the hesitation of this species observed at heights of $180 \mathrm{~cm}$. is due to visual impressions, not to the unusual organic impressions received. This species at first tries to remove the covering from the eyes by rubbing the fore legs over the head, but failing it soon becomes accustomed to the blindfolded condition.

" $N$. guttata is much disturbed by the obstruction of its vision, and for long periods persistently tries to remove the cap. Most individuals after a time move about freely, but whenever they reach the edge of the board they turn back. Evidently the tactual and muscular impressions inhibit the tendency to move forward. Whereas in the case of C. picta, we see the blindfolded animal risking falls which it would not have risked in its normal condition, in $N$. guttata we see exactly the reverse, for as a rule the animal when blindfolded does not leave the board.

" $T$. carolina does not struggle so persistently to remove the covering as do the other species, but it is inactive when blindfolded. It behaves in general much as it does when placed at a height of $180 \mathrm{~cm}$. above the floor. This indicates that it depends upon vision for guidance 
in its movements to such an extent that it is not likely to move about much unless it can see clearly."

His deductions are: "(1) The time spent on the board is shortest for the water species, longest for the land species. This indicates that the hesitation in the presence of a void increases as we pass from the strictly water forms to those which are land inhabiting; (2) Total inhibition of the reaction, i. e., failure to crawl over the edge of the board in the 60 minutes, appears at a much less height for the land species than for the water-land and water forms."

Food Habits.- The Box Tortoise subsists on a mixed diet, consisting of vegetable matter on the one hand and animal matter in the form of insects, snails, slugs, etc., on the other. Latham has observed that it feeds on the mushroom Russula obscura. Surface records the stomach contents of forty individuals of this species to include: mushrooms, moss, roots, leaves, buds, berries, seeds, grass, blackberry seeds, apple seeds, cherry seeds, sweet cicely, wintergreen, ground cherry, birds' wheat moss, earthworms, slugs, snails, crayfish, millipedes, insects, grasshoppers, crickets, bugs, larvae of butterflies and moths, flies, beetles, and portions of mice. Captive animals are practically omnivorous, but are especially fond of blackberries, strawberries, and partly decayed bananas. They have been observed to disembowel toads; kill and eat small brown snakes; and devour the large black slug, Arion. They drink copiously of water at times, some animals learning to "seek the neighborhood of sink or faucet, and with head ereet beg for water" (Smith). They drink with the head submerged. Captive specimens sometimes become so fat that it is impossible for them to close both portions of the hinged plastron at once. The tenacity of life of these reptiles is illustrated by an observation by Shufeldt (1897) who says that he has kept them for a year without food or water. Box Tortoises sometimes come into disrepute with melon growers for biting out pieces of cantaloupes as they lie on the vines.

Enemies.- Healthy adult individuals are practically immune from danger owing to the powerful muscles which close the plastron, so that no predaceous animal of this region is able to tear the shell apart. Eggs and young animals are devoured by skunks. Barrows (1895) has reported young Box Tortoises in stomach contents of Crows. The following observation was made by DeKay (1842): "It is frequently kept in cellars, under the notion that it drives away or destroys rats and other domestic vermin. One which I kept in my cellar, was found in the spring, eaten up by the rats." Larvae of a certain species of bot-flies have been found in the epidermis about the neck, in Box Tortoises.

Economic Importance.- The flesh of this turtle is edible but is not generally used as food. During the coal miners' strike of 1902, in the vicinity of Scranton, Pennsylvania, many miners roamed over the hills and captured and ate turtles which made them sick. It is probable that these were Box Turtles, and the flesh may have been rendered temporarily poisonous to man from a diet of toadstools, of which the turtles are very fond and which does not seem to poison them. New York, however, has found it necessary to pass a law for its protection. 


\section{Family TRIONYCHIDAE.}

Amyda spinifera (LE SUEUR).

\section{Spiny SofT-Shelled Turtle.}

Plate 32.

Trionyx spmniferus Le Sueur, Mém. Mus. d'Hist. Nat. Paris, Dec. 1S27, vol. 15, p. 25S, pl. 6.

Amyda spinifera Hurter, Trans. Acad. Sii. St. Louis, 1911, vol. 20, p. 251.

The Spiny Soft-shelled Turtle belongs to a family of Chelonians which next to the sea turtles, is the most persistently aquatic in its habits.

Size.- The measurements of a mature female specimen are: length of carapace, 14 inches; width of carapace, 12; length of plastron, 10 ; length of tail, $3 \frac{1}{4}$; width of head, $1 \frac{3}{4}$; width of spread hind foot, $3 \frac{1}{4}$; weight, $7 \frac{1}{2}$ pounds (Ditmars, 1907, p. 77).

Thompson (1853, p. 30) gives the measurements of three Vermont (Lake Champlain) specimens as follows:

$\begin{array}{llll} & \text { Length } & \text { Breadth } & \text { Height } \\ \text { No. } 1 & 11 \text { inches } & 9.5 \text { inches } & 2.2 \text { inches } \\ \text { No. } 2 & 13 \text { " } & 10.75 \text { " } & 3.2 \text { " } \\ \text { No. } 3 & 13.5 \text { " } & 11 \text { " } & 3.5 \text { " }\end{array}$

Color.- The carapace is dull olive or yellowish brown. The plastron is white, having a narrow yellow border, internally margined with black. In young specimens the carapace is dotted all over with small ocellated spots which increase in size with age and finally fade into irregular blotches. The head is olive-colored and on each side is a yellow black-bordered stripe which extends from the neck through the eye and meets its fellow at the base of the snout. The extremities are brownish or olive, blotched with black.

Description.-The body is strikingly flat and bluntly oval, covered with soft leathery skin instead of with horny shields. The ossification of the carapace is very incomplete peripherally, the ribs extending considerably beyond the costal plates. The marginal plates are absent, so that the edge of the carapace droops like a flap over the head and extremities. The carapace sometimes presents a keel and well defined rugosities, and in adult and old specimens there are prominent conical spiny tubercles on the anterior margin. The plastron also is imperfectly ossified, the bones being much reduced and only loosely associated. The head and neck are wholly retractile, bending by a sigmoid curve in a vertical plane. The jaws which are sharp and powerful are concealed by soft, lip-like flaps, and the nose forms a soft, slender tube-shaped proboscis. This prolongation of the nostrils into a leathery tube is an 
adaptation due to habits; for respiration is more easily performed as the animals lie buried in the mud in shallow water. The skull is noticeably flattened (a mark of inferiority). The limbs are broadly webbed, only the three inner digits being provided with claws. The tail is short.

The Iung capacity of the Soft-shelled Turtle is less than that of other fresh-water terrapins. An accessory respiratory apparatus which seems to supplement the pulmonary breathing has been described. It consists of specialized mucous membrane situated in the pharynx that acts like gills, as in tadpoles. Gage (1SS4) has observed in captive animals that the mouth and throat are alternately filled with water and emptied at the rate of fifteen times a minute. He believes the respiration of these turtles to be a combination of true aquatic and aërial breathing.

Geographic Distribution.- The principal area of distribution for this species is the region of the Mississippi and its tributaries, but the range extends eastward to Pennsylvania and New York, and northward to Lake Champlain and some of the tributaries of the St. Lawrence.

New England Records.- New England's only claim to this species is the fact of its occurreuce on the eastern shore of Lake Champlain in Vermont. This was first recorded by Thompson $\left(1853\right.$, p. 28). His first specimen ${ }^{1}$ was taken in Minton, Vermont, on August 10, 1844. Most subsequent specimens have been taken in that vicinity about the mouth of the Winooski River and near Burlington. In the Proceedings of the Boston Society of Natural History for 1850 (rol. 3, p. 322), is a note of the donation of a living specimen of "Trionyx ferox" from Rev. Zadock Thompson of Burlington, Vermont. The record says: "The former was taken upon a fish-hook by some boys, while fishing near the mouth of Winooski River; this is the third individual he had obtained in that neighborhood. The specimens there obtained have been much larger than the measurements given by DeKay." There is a young specimen, taken in White River, Vermont, in the collection of the Boston Society of Natural History.

Holbrook (1842, vol. 2, p. 15), who did not distinguish T. ferox from T. spinifer, comments as follows on the physical factors in its northern distribution. He says: "The Trionyx ferox affords an admirable illustration of the influence of physical geography in the distribution of animals. Thus, it inhabits the Savannah as well as all those rivers that empty into the northern borders of the Gulf of Mexico; it ascends up the broad Mississippi, and is found in all its tributaries, even to the very foot of the Rocky Mountains, according to Lewis and Clark; it abounds in the chain of great northern lakes both above and below the Falls of Niagara; and is 'common' in the Mohawk, a tributary of the Hudson river; but is not found in any other Atlantic stream between that and the Savanuah river, a distance of nearly eight hundred miles. Now a glance at the map of the United States will show us how this tortoise,

\footnotetext{
${ }^{1}$ He calls it Triony.x ferox, not distinguishing the northern form. This turtle was reported from Lake Champlain in the American Sportsman by "M. G." in 1S74.
} 
doubtless originally a western species, and never migrating by land, can have passed by water from the Great Valley of the Mississippi to the northern lakes, and to the Mohawk and even Hudson river. At the source of St. Peter's river in times of flood there is a free communication with Red river of Lake Winnipeg, (lat. $48^{\circ}$, Say, in Long's Exp.;) which thus affords a passage for the Trionyx ferox to the Lake of the Woods. Again, the Upper Illinois is well known to communicate with the waters of Lake Michigan in spring floods, so that even loaded boats may pass; and in this way does our animal reach the chain of lakes, that open into the St. Lawrence river. Lastly, previous to the construction of the New York Canal, Wood creek, at the head of the Mohawk, also at 'spring floods' communicated with the waters of the Oswego river; and consequently there the Trionyx could pass to and become 'common in the Mohawk,' and reach the Hudson, though absent from every other river opening into the Atlantic, between the St. Lawrence on the one hand, and the Savannah river on the other."

The connection of the Champlain Valley and the St. Lawrence basin probably accounts for the occurrence in Lake Champlain.

Habitat.- Soft muddy bottoms of rivers and ponds, usually in shallow water.

Numbers. - In the central portion of its range, this turtle is abundant.

Breeding Habits. - The eggs are deposited during June in sandy soil not far from the water, the female sometimes burying herself almost completely during the process. The process of laying the eggs has been observed to require in certain instances several days for its completion. Several dozen round, white, brittle, thin-shelled eggs are deposited, averaging slightly over one inch in diameter. Mitsukuri (1905, p. 263) gives an interesting account of the breeding habits of an allied species, Amyda japonica. He says: "The process of egg deposition is very interesting. A female comes out of the water and wanders about a little while on the banks of the pond in search of a suitable locality in which to deposit eggs. Having finally chosen a spot, with her head directed up the bank she firmly implants her outstretched fore feet on the earth, and during the whole operation never moves these. The process of egg deposition, which takes altogether about twenty minutes, may be divided into three portions occupying about the same length of time, namely: (1) digging a hole, (2) dropping eggs in it, and (3) closing the hole. The digging of the hole is done entirely with the hind legs. Each with its nails outstretched is moved firmly from side to side - that is, the right foot from right to left and the left from left to right, and the two are worked in a regular alternation, while the body is swayed a little from side to side, accompanying the motion of the legs. The force put in the lateral pressure of the feet is so strong that the earth that has been dug out is sometimes thrown off to a distance of 10 feet or more, although the largest part of it is heaped up around the hole. Digging seems to be continued as long as there is any earth within the reach of the legs to be brought up. The result is a squarish hole with the angles rounded off, and although its size differs with the size of the female, it is generally about 3 to 4 inches across 
at the entrance, with the depth and width inside about 4 inches or more. When the digging is finished eggs are dropped from the cloaca into the hole, which naturally lies just below it. The eggs are heaped up without any order, but, there being no chalazae, the yolk is able to rotate in any direction, and the blastoderm, having the least specific gravity, always occupies the highest spot of the yolk in whatever position the egg may happen to be dropped.... .

"When the eggs have all been deposited, the turtle's legs are again put in requisition, this time to fill up the hole, which is done by alternate motions as before. The earth about the hole is used at first, but search is made for more loose earth for a little distance, as far around as the legs can reach with a slight motion of the body either to the right or left without moving the front legs. Toward the end of the process the loose earth is trampled down. When the hole is well filled up to the level of the ground, the turtle turns around and goes immediately down into the water, not casting even one backward glance.

"I have noticed an interesting contrast between the behavior of Trionyx and of Clemmys during the egg deposition. If one wants to watch a Trionyx depositing eggs, one has to crawl on all fours behind the plank wall of the pond and peep through a hole, being careful not to show himself. The moment the snapping turtle sees anyone, it stops in whatever part of the egg-laying process it may be engaged and plunges straight into the water. Utterly different is the behaviour of Clemmys. When once it begins the process of egg-laying it is never deterred from carrying it out, no matter how near or how boldly one may approach."

He gives the following table of the rate of growth for this species:-

$\begin{array}{lccc}\text { Age } & \begin{array}{c}\text { Length in } \\ \text { Centimeters }\end{array} & \begin{array}{c}\text { Breadth in } \\ \text { Centimeters }\end{array} & \begin{array}{c}\text { Weight in } \\ \text { Grams }\end{array} \\ \text { Just hatched } & 2.7 & 2.5 & - \\ \text { First year } & 4.5 & 4.2 & 23 \\ \text { Second year } & 10.5 & 8.8 & 169 \\ \text { Third year } & 12.5 & 10.5 & 300 \\ \text { Fourth year } & 16.0 & 13.5 & 563 \\ \text { Fifth year } & 17.5 & 15.1 & 750\end{array}$

Habits. - This turtle is largely aquatic, probably never leaving the water except to deposit its eggs. Its savage disposition has earned for it in some localities the name of Soft-shelled Snapping Turtle. An amusing example of this is here given, that occurred somewhere in "Lower Canada" in 1648: " "A Frenchman eaught one of considerable size, which he thought he had killed with a club; he tied a string to its tail, and threw it over his shoulder. IVhen the animal, which is rather tenacious of life, recovered from the stupor caused by the blows discharged on its head, it seized its foe by the back with its small jaws, and bit him so hard that he yelled with pain. He dropped the cord, to allow the tortoise to fall; but it would not

${ }^{1}$ Jesuit Relations, edited by G. Thwaites, 1901, vol. 33, p. 47. 
loosen its hold, and remained suspended by its teeth, biting harder and harder, without letting go; finally its head had to be cut off, in order to appease its anger."

Another instance is recorded by DeKay (1842), who says: "Dr. Eights . . . asserts that he saw a large one from Cayuga lake dart out its head ferociously at a dog which had been purposely brought near, and take from its side a mouthful of hair in the attempt."

Agassiz (1857, vol. 1, p. 333) writes: "The principal habitat of the members of this family is the muddy bottom of shallow waters. They bury themselves in the soft mud, leaving only the head, or a small part of it, exposed. They take breath from time to time, without moving the body, by raising up the long neck and head and carrying the leathery snout above water. They sometimes stay under water a long time, without taking breath; in one instance, a specimen has been seen to remain under water for more than half an hour without raising its snout above the surface. The nature of the habitat is clearly connected with some of the prominent family characteristics. For instance, the buried body needs not the protection of the fully ossified shield which the other families have; the long neck and head, the projecting snout, and the free communication between the nasal openings and the mouth are all connected with the manner of taking breath. These animals rarely go on dry land, and when they do, their locomotion is laborious and constrained; yet it is identical with that of the other Amydae in the alternation of the limbs of the two sides of the body. When moving through the water, they strike horizontally with both pairs of limbs, alternating however between the right and left foot of each pair; but when they start suddenly, the front limbs are seen moving together towards the tip of the snout, and then striking simultaneonsly backward with great power to propel the body forward. As the shoulders are placed so near the edge of the body, and the shield does not project free about the front end, the front himbs move mostly beyond the shield, in front and at the sides; and as the outer edge is sharp, and the fcet are broad, their web reaches above as well as below the plane of that edge, and when they strike, they drive the water back, partly over and partly under it. The hind legs move back and forth below the carapace and drive the water backward without hindrance, for the flexible broad rim is so light in the water that it yields readily to the current. When these animals move along on the bottom, the limbs still move horizontally, the web striking against the water, and the inner toes against the bottom. They also burrow horizontally, going under the mud only to the depth of a thin layer. When burrowing, they carry the hind feet forward and outward, and thus bracing themselves, press the body forward, digging a part of the mud with the fore feet, and raising a part of it up on the body; the mud is loosened by the strong inner toes, but the whole foot aids in removing it. In walking on dry land, the legs move as nearly horizontally in propelling the body forward as is consistent with the resistance offered by the ground. The animal readily resorts to the shield for protection. The neck and head are withdrawn entirely within the shield, the skin rolling off from the greater part of the neck, and allowing it to pro- 
trude naked among the viscera. The legs are withdrawn horizontally, and the skin slips off so far that it does not surround them, except below the knees and elbows. When thus withdrawn, the humerus is carried round into or before the widespread scapular arch, the elbow being placed very near the head or neck; the fore leg and foot are turned back upon the humerus, the flat surface of the foot being nearly horizontal, so that its outer edge rests against the humerus. The knee is carried almost directly forward, the fore leg turned backward against the femur, and the foot again turned somewhat forward, its flat surface being nearly horizontal.

"It is easy to perceive the close relations which exist, in this family, between the mode of locomotion, the movements and position of the limbs, and the general form of the body. The limbs, for example, move and are withdrawn horizontally; so also is the body widely stretched out horizontally, and moreover it is flat and low. The flat front end offers little resistance to the water before it; its sharp outer edge offers as little resistance also to the water which is driven back by the fore feet. Again, this low end is well adapted to entering the mud, and the fore feet to loosen and remove as much of it as is necessary to enable them to bury themselves in the soft ground. The flattening of the carapace backward is necessary to allow free horizontal movement to the hind legs."

Thompson wrote regarding his Vermont specimens: "This species resembles the sea-turtle, in its structure and habits, much more than our other tortoises. It leads a more aquatic life, and, probably seldom, if ever, crawls out upon the land, except for the purpose of depositing its eggs. On account of the shortness of its legs, and the great width of the shell, it travels upon land with much difficulty, especially where the surface is uneven, or covered with vegetation. Its flesh is esteemed a wholesome and nutritious article of food."

In captivity these turtles thrive if provided with suitable environment. My young specimens were fond of burying themselves completely, except for the tip of the snout, in the sand on the bottom of the tank, and would remain there for hours.

Food Habits. - The Soft-shelled Turtle is a voracious feeder and is chiefly carnivorous; fresh-water mollusks (Anodonta and Campeloma), small fish, tadpoles, frogs, and other aquatic life constitute its diet. Surface found the stomach contents of two turtles of this species to be composed of crayfish, beetles and other insects. It is also a scavenger.

Economic Importance.- This turtle, where abundant, is sold and used for food. In Japan the Soft-shelled Turtle (A. japonica) is raised commercially on "turtle farms" and assumes the place occupied among "gastronomical delicacies" by the Diamond-back Terrapin in the United States and by the Green Turtle in England. It has been estimated that the output from one establishment for their artificial propagation was 82,000 eggs, producing 70,000 young turtles in one year (1904).

Boulenger (1914, p. 40) quotes the following account of the method of capturing another species, the Amyda gangetica (Asia); "In hunting for the soft Turtles in the hill streams, the 
men use a long iron fork, such as an old iron ramrod, sharpened at one end, or a stout strip of bamboo, which they thrust down for a foot or two in the soft vegetarian sludge and decayed leaves found along the margins of deep pools in the hill-streams.

"If a fork touches a Turtle concealed below, the motion of the animal is felt: a cautious examination is then made with the hand, and a fish-hook is cleverly inserted in the soft part about the tail. A steady haul is now made, and out comes the Turtle, wildly floundering and snapping at everything within its reach with pertinacious ferocity.

"Sometimes, when the animal is large and the water deep, a stake is held over the animal's back, and with a few well-delivered blows of a mallet, driven through both shells. Woe betide the limb, however, which comes within reach of the infuriated animal! I saw the top of a man's toe bitten clean off by a trionyx which was being 'staked,' and, as these animals are both active and ferocious, it is always advisable to send a bullet through their brain as soon as possible. So tenacious of life, however, are these creatures, that their heads bite vigorously after being completely dissevered from their bodies."

These turtles often annoy the fisherman by taking his baited hook and are very destructive to young fish and water-fowl. 



\section{LITERATURE.}

Agassiz, Louis.

1857. Contributions to the natural history of the United States of America. Boston, 4to, (4 vols.) vol.

Allen, J. A. 1, p. i-lii, 1-450; vol. 2, p. 451-643, pl. 1-27.

1868. Catalogue of the reptiles and batrachians found in the vicinity of Springfield, Mass., with notices of all the other species known to inhabit the state. Proc. Boston Soc. Nat. Hist., vol. 12, p. 171-204, 248-250.

1870. Notes on Massachusetts reptiles and batrachians. Proc. Boston Soc. Nat. Hist., vol. 13, p. 260263. See also p. 320 .

Babcock, H. L.

1916. Notes on an unusual feeding habit of the Snapping Turtle, Chelydra serpentina (Linn.). Copeia, no. 37 , p. 89-90.

1916a. An addition to the Chelonian fauna of Massachusetts. Copeia, no. 38, p. 95-98.

1917. An extension of the range of Clemnys muhlenbergii. Copeia, no. 42, p. 32.

Bangs, Outram.

1896. An important addition to the fauna of Massachusetts. Proc. Boston Soc. Nat. Hist., vol. 27, p. 159-161.

Barrows, W. B., and Schwarz, E. A.

1895. The Common Crow of the United States. Bull. U. S. Dept. Agric., Div. Ornithology and Mam-

Bates, H. W. malogy, no. 6, 98 pp. (see p. 48).

1863. The naturalist on the River Amazons, etc. London, Svo, illus., vol. 1, p. i-x, 1-351; vol. 2, p. i-iv, $1-423$.

Boulenger, E. G.

1914. Reptiles and batrachians. London, Svo, xiv +278 pp., illus.

Boulenger, G. A.

1889. Catalogue of the Chelonians, Rhynchocephalians, and Crocodiles in the British Museum (Natural

Bumpus, H. C.

History). New ed., 311 pp., 6 pls.

1884-86. Reptiles and batrachians of Rhode Island. Random Notes on Nat. Hist., Providence, R. I., vol. 1 , no. 10 , p. 4-5; no. 11 , p. $6-7$; 1885 , vol. 2 , no. 1 , p. 5 ; no. 2 . p. 13 ; no. 3 , p. $20-21$; no. 4, p. 28 ; no. 5, p. $37-38$; no. 6 , p. $41-45$; no. 7 , p. 52-53; no. 8 , p. 59-60; no. 9, p. 68-69; no.

Burroughs, John. 10, p. 75 ; no. 11 . p. $\$ 3-84$; no. 12 , p. 93 ; 1886, no. 1, p. 7-8; no. 2 , p. 13.

1875. Squirrels and other fur-bearers. Boston, Svo, 149 pp., illus.

Coker, R. E.

1906. The cultivation of the Diamond-back Terrapin. N. Carolina Geol. Surv., bull. 14, 69 pp., 23 pls.

1910. Diversity in the scutes of Chelonia. Journ. Morphol., vol. 21, p. 1-76, pl. 1-14.

Coles, R. J.

1914. Egg-laying of the Loggerhead Turtle. Copeia, no. 4, p. [3-4].

Culver, D. E.

1915. Box Tortoise (Terrapene carolina) swimming a creek. Copeia, no. 22, p. 36-37.

DeKay, J. E.

1842. Natural History of New York, Zoölogy, pt. 3, Reptiles and Amphibia. New York, Boston and Albany, 4to, viii +98 pp., 23 pls. 
Ditmars, R. L.

1907. The reptile book. New York, Swo, xxxii +472 pp., illus.

1910. Reptiles of the world. New Tork, Svo, $x x+373$ pp., illus.

Drowne, F. P.

1905. The reptiles and batrachians of Rhode Island. Monogr. 15, Roger Williams Park Museum, Providence, R. 1., p. 1-24.

Eigenmann, C. H.

1896. The inhabitants of Turkey Lake. Testudinata. Proc. Indiana Acad. Sci., vol. 5, p. 262-264.

Engelhardt, G. P.

1916. Burrowing habits of the Box Turtle. Copeia, no. 31, p. 42-43.

Fogg, B. F.

1862. A list of the reptiles and amphibians of Maine. Proc. Portland Soc. Nat. Hist., vol. 1, p. S6.

Forbush, E. H.

1916. The natural enemies of birds. Mass. State Board Agric., Economic Biology, bull. 3,58 pp., 7 pls.

Ford, John.

1579. The Leather Turtle. Amer. Nat., vol. 13, p. 633-637.

Fowler, H. W.

1913. An interesting form of the Snapping Turtle (Chelydra serpentina). Copeia, no. 1, p. [1-2].

1914. The food of the Loggerhead Turtle (Caretta caretta). Copcia, no. 3, p. [4].

Gadow, Hl.

1901. Amphibia and reptiles. Cambridge Nat. Hist., vol. 8 , xiv +668 pp., illus.

Gage, S. H.

1884. Pharyngeal respiration in the Soft-shelled Turtle (Aspidoncetcs spinifor). Proc. Amer. Assoc.

Garman, H. Adv. Sei., vol. 32, p. 316-318.

1592. A synopsis of the reptiles and amphibians of Illinois. Bull. Ill. State Lab. Nat. Hist., vol. 3, p.

Gunther, A. 215-390, pl. 9-15.

1894. Article in Encyclopaedia Britannica, 9th ed., vol. 23, p. 460.

Hay, O. P.

1908. The fossil turtles of North America. Carnegie Inst. Washington, publ. 75, 4to, iv $+568 \mathrm{pp}$,

Hay, IV. P. $113 \mathrm{pls}$.

1905. A revision of Malaclemmys, a genus of turtles. Bull. U. S. Bureau Fisheries for 1905, vol. 24. p. 1-20, pl. 1-12.

Hay, W. P., and Aller, H. D.

1913. Artificial propagation of the Diamond-back Terrapin. IT. S. Bur. Fisheries, Economic Circular,

Henshaw, H. W. no. $5,14 \mathrm{pp}$.

1907. An extension of the range of the Wood Tortoise. Proc. Biol. Soc. Washington, vol. 20, p. 65.

Henshaw, S.

1904. Fauna of New England. 1. List of Reptilia. Occas. Papers Boston Soc. Nat. Hist., vol. 7,

Hitchcock, E. $13+2 \mathrm{pp}$.

1833. Report on the geology, mineralogy, botany, and zoölogy of Massachusetts. Amherst, Svo, xii $+700 \mathrm{pp}$. Also later edition, 1835, under Catalogues of the animals and plants of MassachuHolbrook, J. E. setts, sep. Amherst, $142 \mathrm{pp}$.

1842. North American herpetology; or, a description of the reptiles inhabiting the United States. Philadelphia, 4to, 5 vols., illus. 
Hooker, D.

1911 Certain reactions to color in the young Loggerhead Turtle. Papers from 'Tortugas Lall., Carnegic Inst. Washington, vol. 3, p. 69-76, pl. 1-2.

Hornaday, II. T.

1914. The American natural history. New York, 4 vols., illus.

Howe, R. H., Jr.

1911. The second record for Blanding's Turtle in Concord, Mass. Scicuce, new ser., vol, 34, p. 272.

Huse, W. H.

1901. The Testudinata of New Hampshire. Proe. Manchester Inst. Arts and Sciences, vol. 2, p. 47-51.

Jordan, D. S.

1599. A manual of the verfebrate animals of the Northern United States. Fighth el.

Latham, R.

1916. Notes on Cistudo carolina from Orient, Long Island. Copeia, no. 34, p. 61-67.

1917. Studying the Box Turtle. Copeia, no. 40, p. 15-16.

Linsley, J. H.

1813. A eatalogue of the reptiles of Connecticut, acranged according to their natural families. Amer.

.Journ. Sci. and Arts, ser. 1, vol. 46, p. 37-51, (see P'ostscript).

Lucas, F. A.

1916. Oecurrence of Pseudemys at Plymouth, Mass. Copeia, no. 3S, p. 9S-100.

Mast, S. O.

1911. Behavior of the Loggerlsead Turtle in depositing its eggs. Papers fron 'Tortugas Lail)., Carnegie

Inst. Washington, vol. 3, p. 63-68.

Mitsukuri, K.

1905. The cultivation of marine and fresh-water animals in Japan. Bull. U. S. Bur. Fisheries for 1904, vol. 24 , p. 259-290, pl. 1-11.

Morse, M.

1904. Batrachians and reptiles of Ohio. Proc. Ohio State Acad. Sci., vol. 4, pt. 3 (Spccial Papers, no. 9),

Murphy, R. C.

p. $95-144$, pl. 1 .

1916. Long Island turtles. Copeia, no. 33, p. 56-60.

Nichols, J. T.

1914. Box Turtle active in December. Copeia, no, 3, p. [1].

1914a. Mud Turtle attacked by crab. Copeia, no. 12, p. [3].

Nick, L.

1912. Das Kopfskelet von Dermochelys coriacea L. Zoöl. Jahrbücher, Abth. f. Auat., vol. 333, p. 1-235, pl. 1-12.

Osborn, H. F.

1917. The origin and evolution of life. New York, Svo.

Overton, F.

1916. Aquatic habits of the Box Turtle. Copeia, no. 26, p. 4-5.

Parker, G. H.

1901. Correlated abnormalities in the seutes and bony plates of the carapace of the Sculptured Tortoise.

Pycraft, IV. P.

Amer. Nat., vol. 35, p. 17-24.

1914. The courtship of animals. New York, Svo, $31 \mathrm{~s}$ pp., illus.

Rogers, C. H.

1917. Notes on three common New Jersey turtles. Copeia, no. 47, p. 74-76.

Rosenberger, R. C.

1916. Interesting facts about turtles. Forest and Stream, vol. S6, p. 764-765. 
Schenck, J.

1856. Longevity of turtles. Amer. Nat., vol. 20, p. 897.

Schoonhoven, J. J.

1911. Blanding's Turtle. Science, new ser., vol. 34, p. 917.

Scott, W. B.

1913. A history of land mammals in the western hemisphere. New York, $8 v 0$, xvi +693 pp., illus.

Sears, J. H

18S6. Dermatochelys coriacea, Trunk Back or Leathery Turtle. Bull. Essex Inst., vol. 18, p. S7-94.

Sharp, D. L.

1911. The face of the fields. Boston, Svo. Containing chapter on Turtle eggs for Agassiz.

Shufeldt, R. W.

1897. Chapters on the natural history of the United States.

1916. Incidents of animal intelligence. Our Dumb Animals, vol. 49, p. 123.

Smith, D. S. C. H., see Hitchcock, L., 1833, 1 \$ 35.

Smith, Eugene.

1899. The turtles and lizards found in the vicinity of New York City. Abstract Proc. Linnaean Soc.

New York, 1898-9, p. 11-32.

Smith, H. M.

1904. Notes on the breeding habits of the Yellow-bellied Terrapin. Smithsonian Misc. Coll., vol. 45, p. $252-253$.

Snith, W. H.

1879. Catalogue of the Reptilia and Amphibia of Michigan. Supplement to Science News, p. i-viii.

Stejneger, L., and Barbour, T.

1917. A check list of North American amphibians and reptiles. Cambridge, 8 vo, $125 \mathrm{pp}$.

Storer, D. H.

1840. A report on the reptiles of Massachusetts. Boston Journ. Nat. Hist., vol. 3, p. 1-61, pl. 1.

Sumner, F. B.

1909. The Biological Laboratory of the Bureau of Fisheries at Woods Holc, Mass. Report of the past year's work, and announcement for the coming season. Science, new ser., vol. 29, p. 9S3-987.

Sumner, F. B., Osburn, R. C., and Cole, L. J.

1913. A biological survey of the waters of Woods Hole and vicinity. Bull. U. S. Bur. Fisheries for 1911, vol. 31 , p. $1-860$.

Surface, H. A.

1908. First report on the economic features of turtles of Pennsylvania. Zoöl. Bull., Div. of Zoöl., Penna. Dept. Agric., vol. 6, nos. 4-5, p. 105-195, pl. 4-12.

Taylor, W. E.

1895. The Box Tortoises of North America. Proc. U. S. Nat. Mus., vol. 17, p. 573-58S.

Tennent, Sir J.

1S61. Sketches of the natural history of Ceylon, etc. London, Sro, xxiv $+500 \mathrm{pp}$., illus.

Thompson, Zadock.

1S42. History of Vermont, natural, eivil and statistical, in three parts, with a new map of the State, and 200 engravings. Burlington, Vt., 8 ro., ii $+224+4$ pp.

1853. Appendix to the History of Vermont, natural, eivil and statistical. Burlington, Svo, p. 1-64.

Thoreau, H. D.

18st. Summer: from the Journal of Henry D. Thoreau. Ed, by H. G. O. Blake.

Verrill, A. E.

1863. Catalogue of the reptiles and batrachians found in the vicinity of Norway, Oxford Co., Me. Proc.

Boston Soc. Nat. Hist., vol. 9, p. 195-199.

Wetmore, $A$, and Harper, $F$.

1917. A note on the hibernation of Kinostcrnon pennsylvanicum. Copeia, no. 45, p. 56-59. 
Williston, S. W.

1914. Water reptiles of the past and present. Chicago, 8 vo, viii +251 pp., illus.

Wright, A. H.

1918. Notes on the Muhlenberg's Turtle. Copeia, no. 52, p. 5-7.

1918a. Notes on Clemmys. Proc. Biol. Soc. Washington, vol. 31, p. 51-58.

Wright, A. H., and Funkhouser, W. D.

1915. A biological reconnaissance of the Okefinokee Swamp in Georgia - The reptiles. Proc. Acad Nat. Sci. Philadelphia, p. 107-192, pl. 1-3.

Yerkes, R. M.

1901. The formation of habits in the turtle. Pop. Sci. Monthly, vol. 58, p. 519-525.

1904. Space perception of tortoises. Journ. Comp. Neurol. and Psychol., vol. 14, p. 16-26.

1905. The color-pattern of Nanemys guttata Schneider (a preliminary report). Science, new ser., vol. 21, p. 386. 

EXPLANATION OF PLATES. 


PLATE 17.

Leather-Back Turtle, Dermochelys coriacea (Linné).

Fig. 1. Side view of a female taken near Block Island, R. I. (Courtesy of American Museum of Natural History.) J. D. Figgins, phot.

Fig. 2. Tentral view of a cast of a male. (Courtesy of American Museum of Natural History.)

Fig. 3. View of head, showing spines in the mouth, of the specimen captured off Block Island, R. I. (Courtesy of Ameriean Museum of Natural History.) J. D. Figgins, phot.

Fig. 4. Plastron of a female, captured on the New Jersey coast, showing the marbling with white. (Courtesy of Brooklyn MIuseum of Arts and Sciences.) R. C. Murphy, phot. 

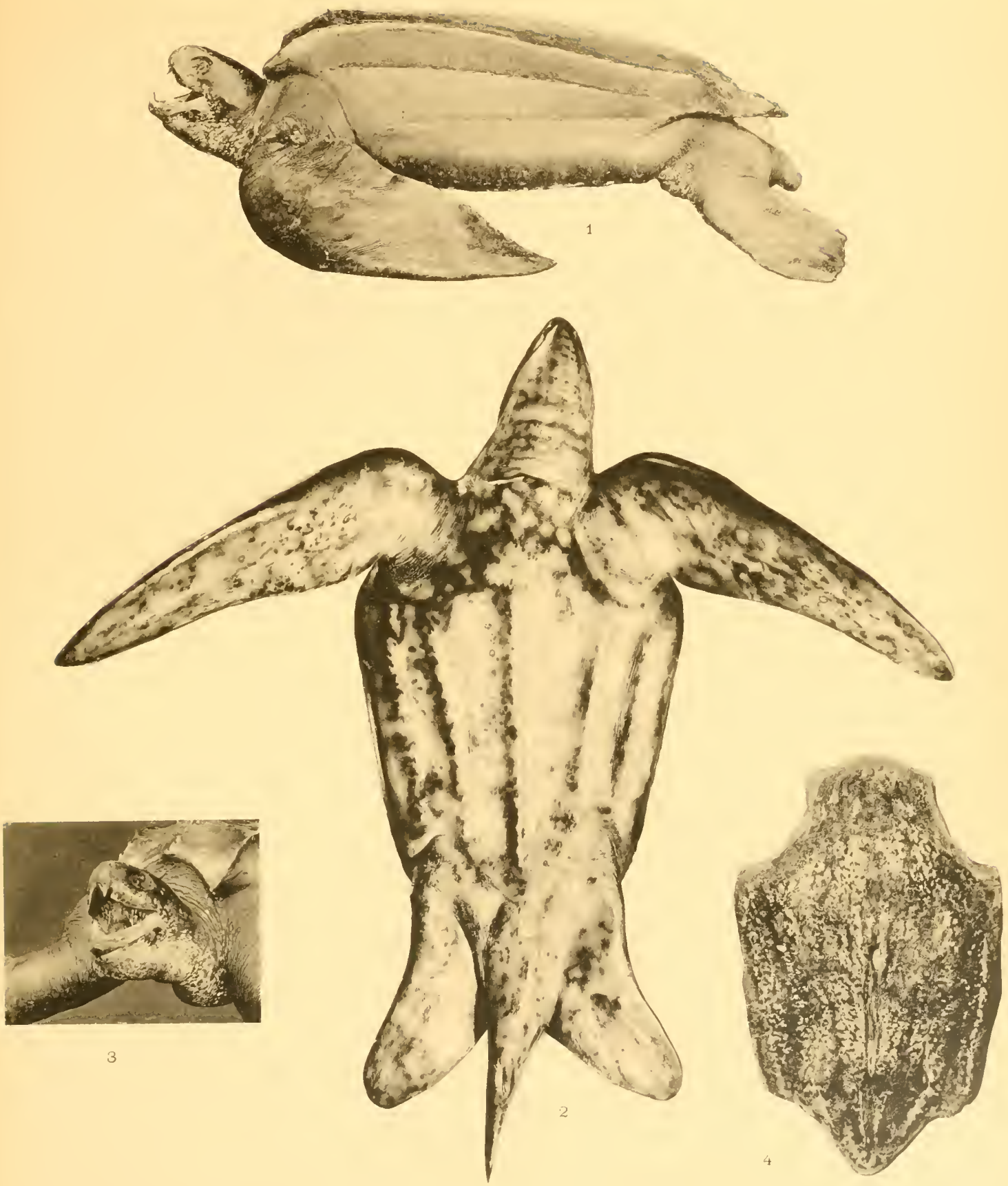

PLATE 18. 


\section{PLATE 18.}

Green Turtle, Chelonia mydas (Linné).

Fig. 1. Upper view. Fig. 2. Lower view. Market specimen.

Loggerhead Turtle, Caretta caretta (Linné).

Fig. 3. Upper view. Fig. 4. Lower view. Market specimen. Note the barnacles on the shell. 

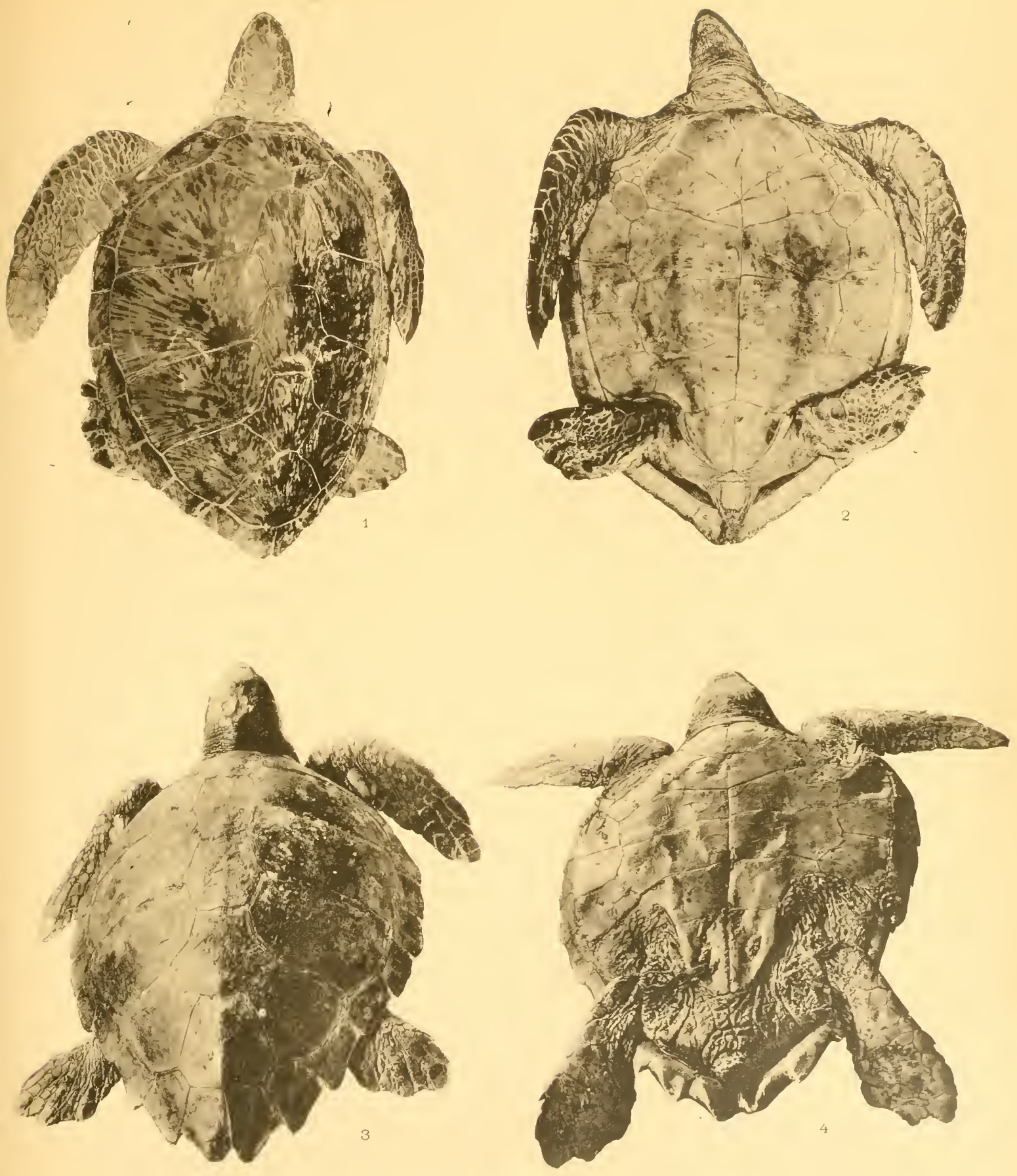

GREEN AND LOGGERHEAD TURTLES. 

PLATE 19. 
PLATE 19.

Hawksbill Turtle, Eretmochelys imbricata (Linné).

Fig. 1. Upper view. Fig. 2. Lower view.

From a young living specimen in the New York Aquarium. 

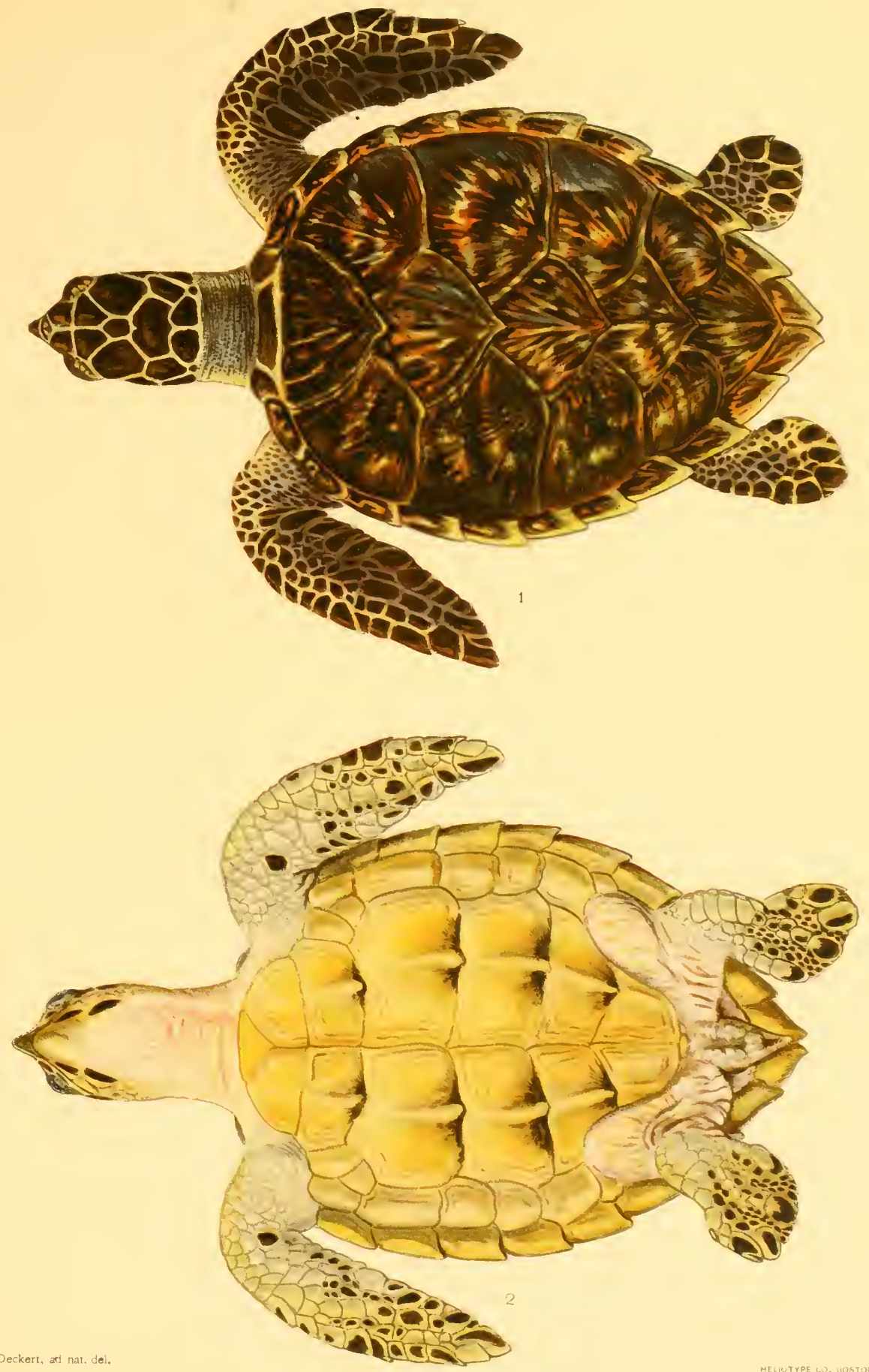

HAWKSBILL TURTLE. 
PLATE 20. 
PLATE 20.

Svapping Turtle, Chelydra serpentina (Linné).

Fig. 1. Side view. Fig. 2. Lower view.

From a young individual living in the New York Zoölogical Garden, near which it was captured. 

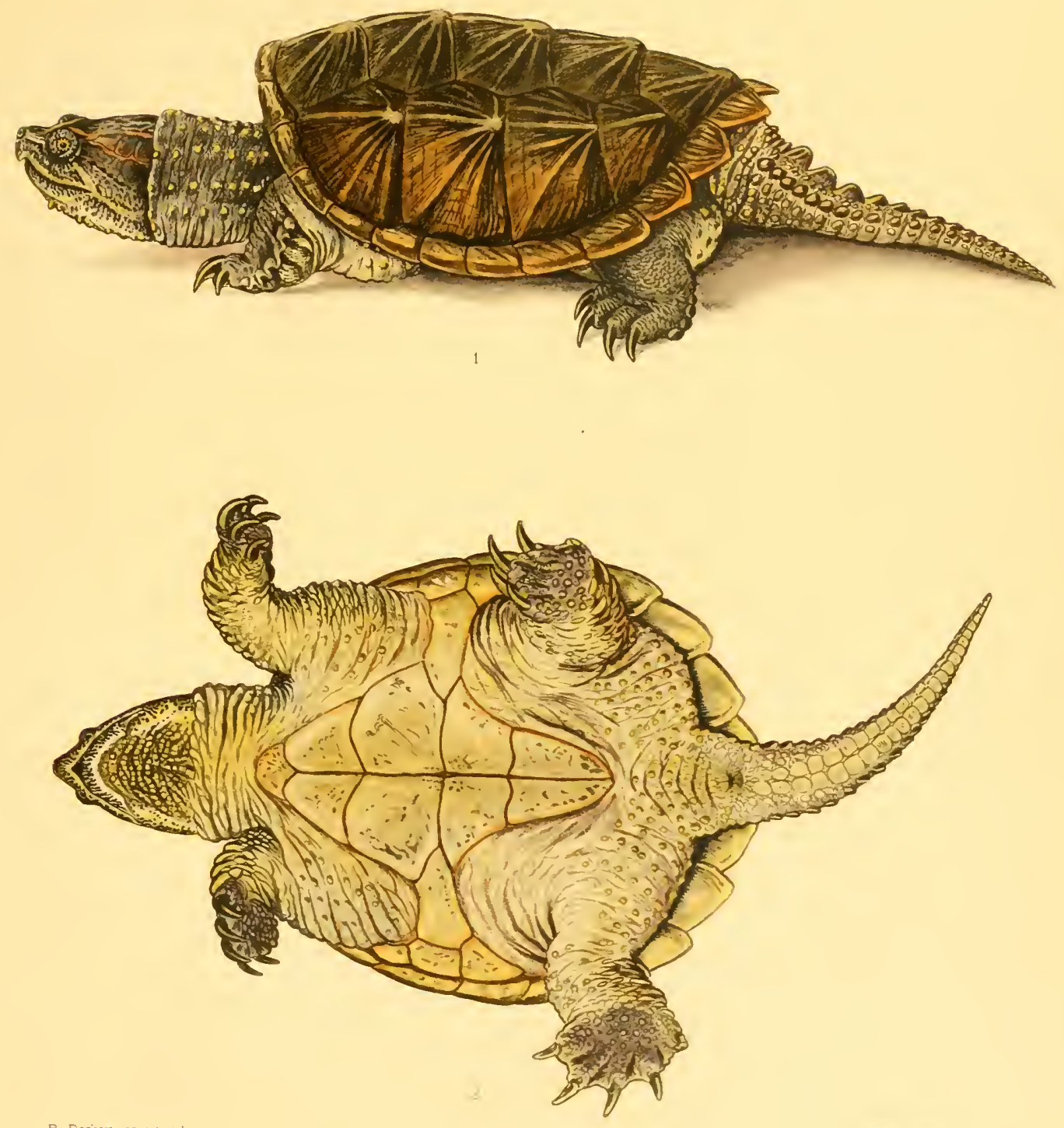

SNAPPING TURTLE. 
PLATE 21 
PLATE 21.

Musk Turtee, Kinosternon odor

Fig. 1. Upper view. Fig.

From a living female example taken in $\mathrm{B} 1$ m. : $:$, 

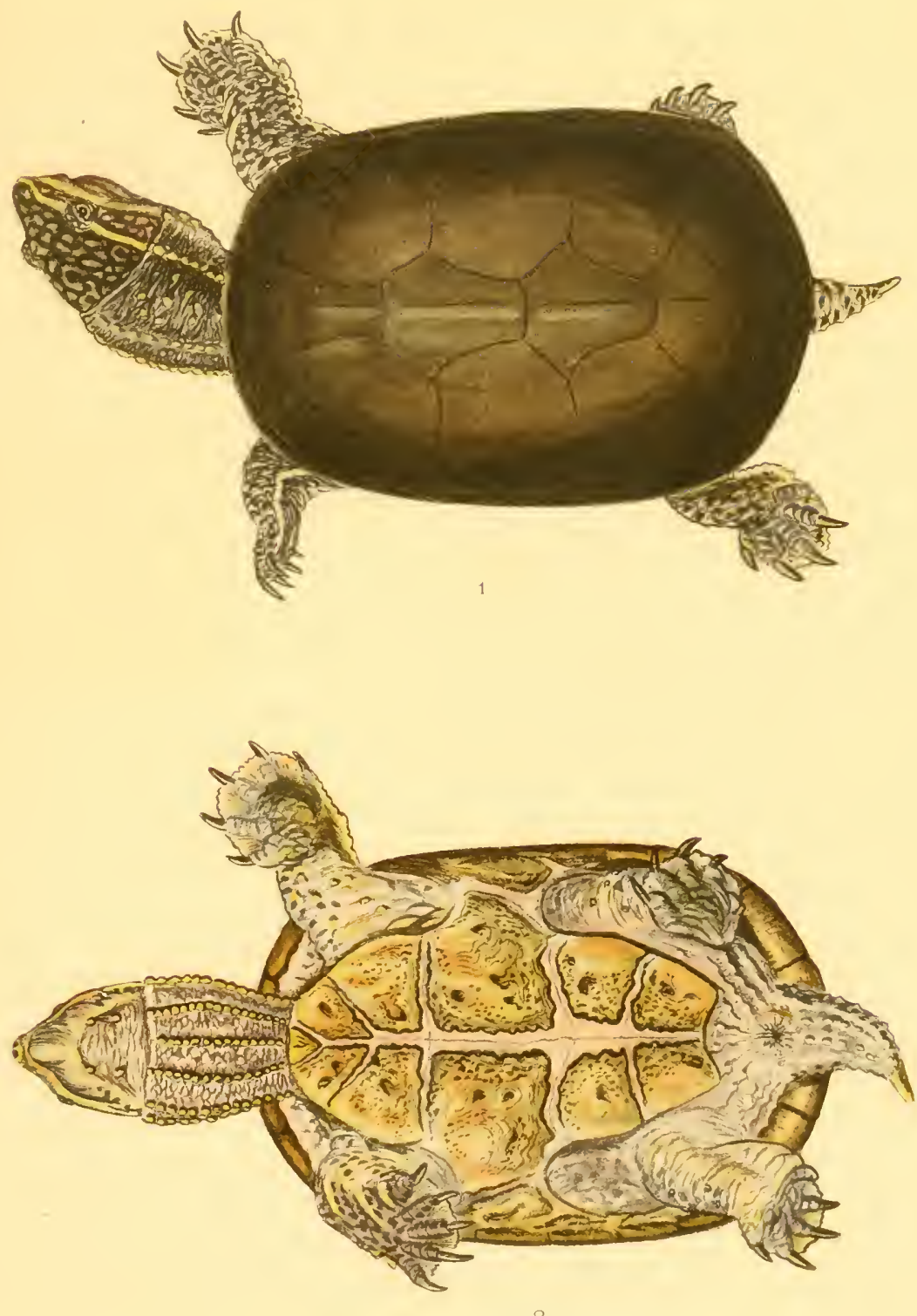
PLATE 22. 
PLATE 22.

Mud TurtLe, Kinosternon subrubrum (Lacépède).

Fig. 1. Upper view. Fig. 2. Lower view.

From a living female example captured in New York. 

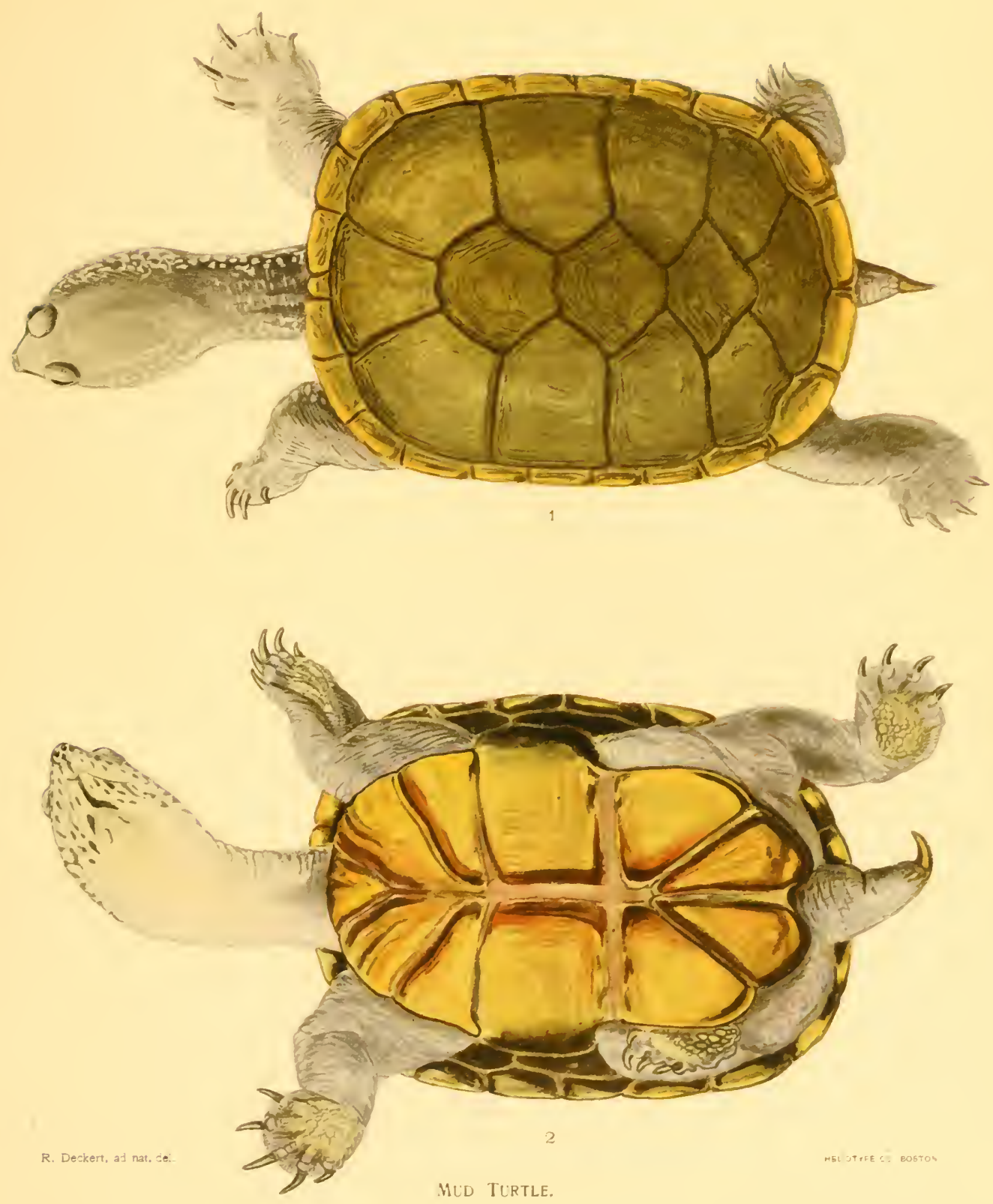




\section{PLATE 23.}

Painted Turtue, Chrysemys picta (Schneider).

Fig. 1. Upper view. Fig. 2. Lower view.

From a living example, female, from Charles River, Dedham, Massachusetts. 

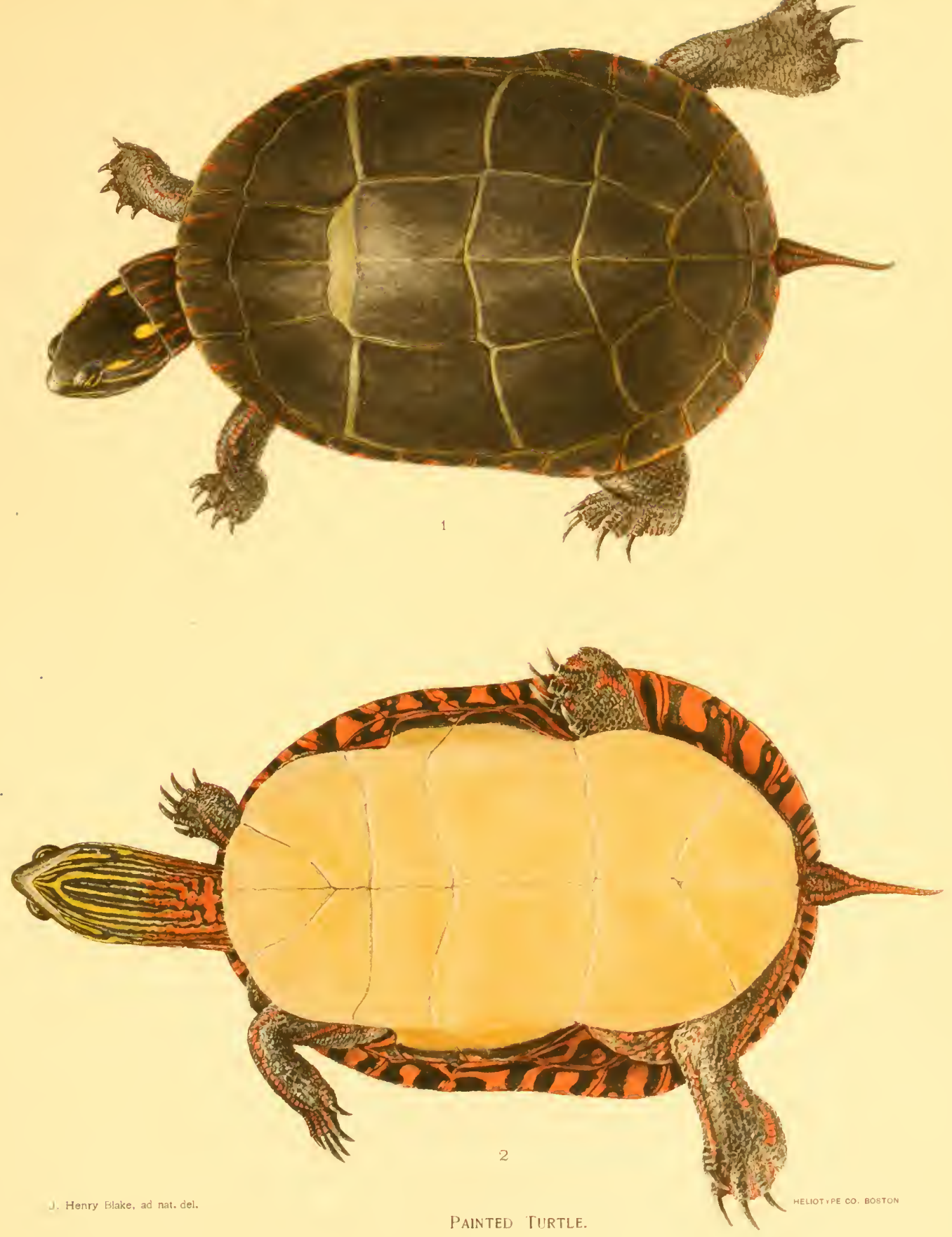

PLATE 24. 


\section{PLATE 24}

Red-bellied Terrapin, Pseudemys rubriventris (LeConte).

Fig. 1. Side view. Fig. 2. Lower view.

From a male specimen captured at Plymouth, Massachusetts. 

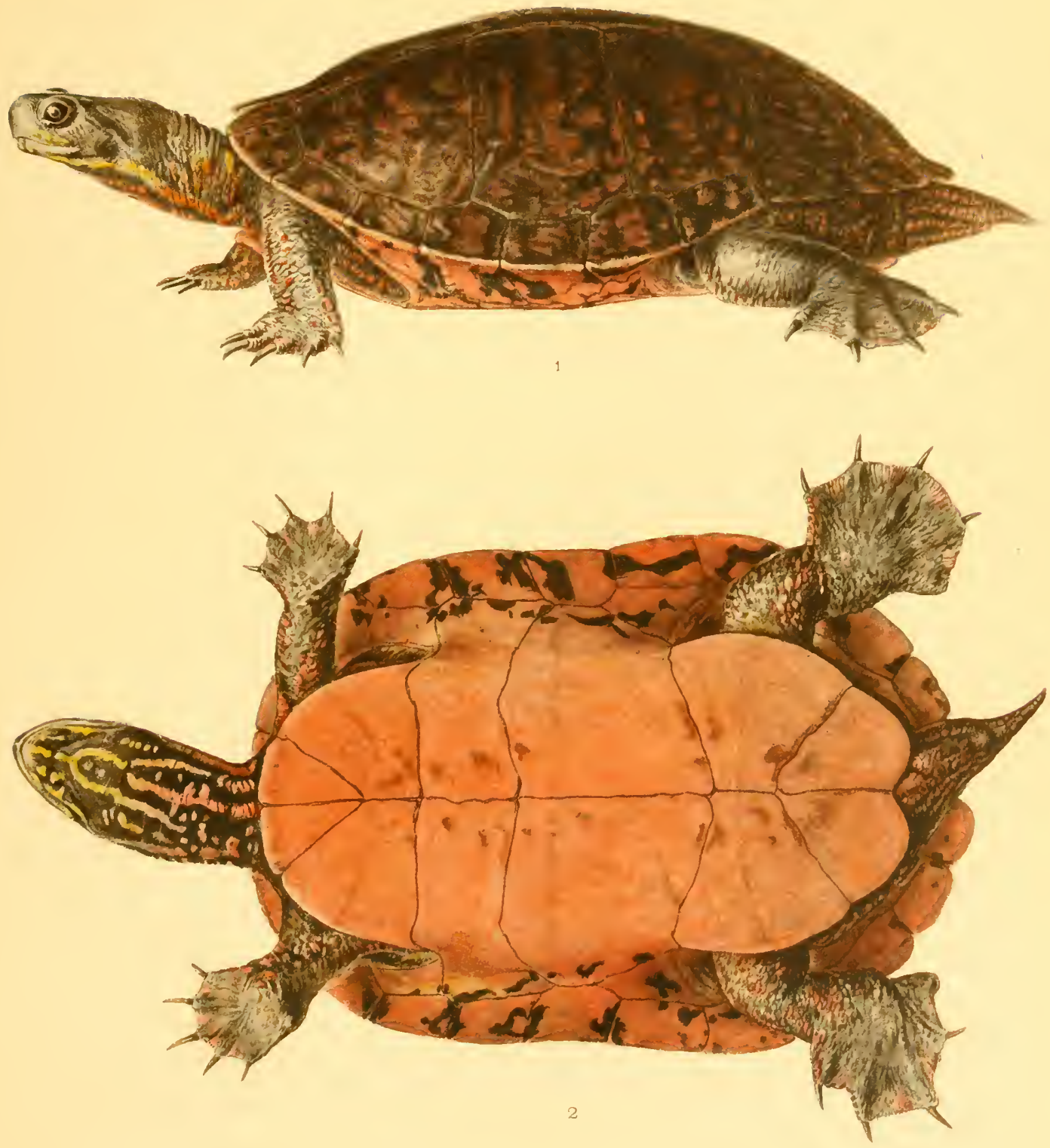

PLATE 25. 


\section{PLATE 25.}

\section{Geographical Terrapin, Graplemys geographica (LeSueur).}

Fig. 1. Upper view. Fig. 2. Lower view.

From a living female captured at Venice, Ohio, and presented by Alexander Nielsen. 

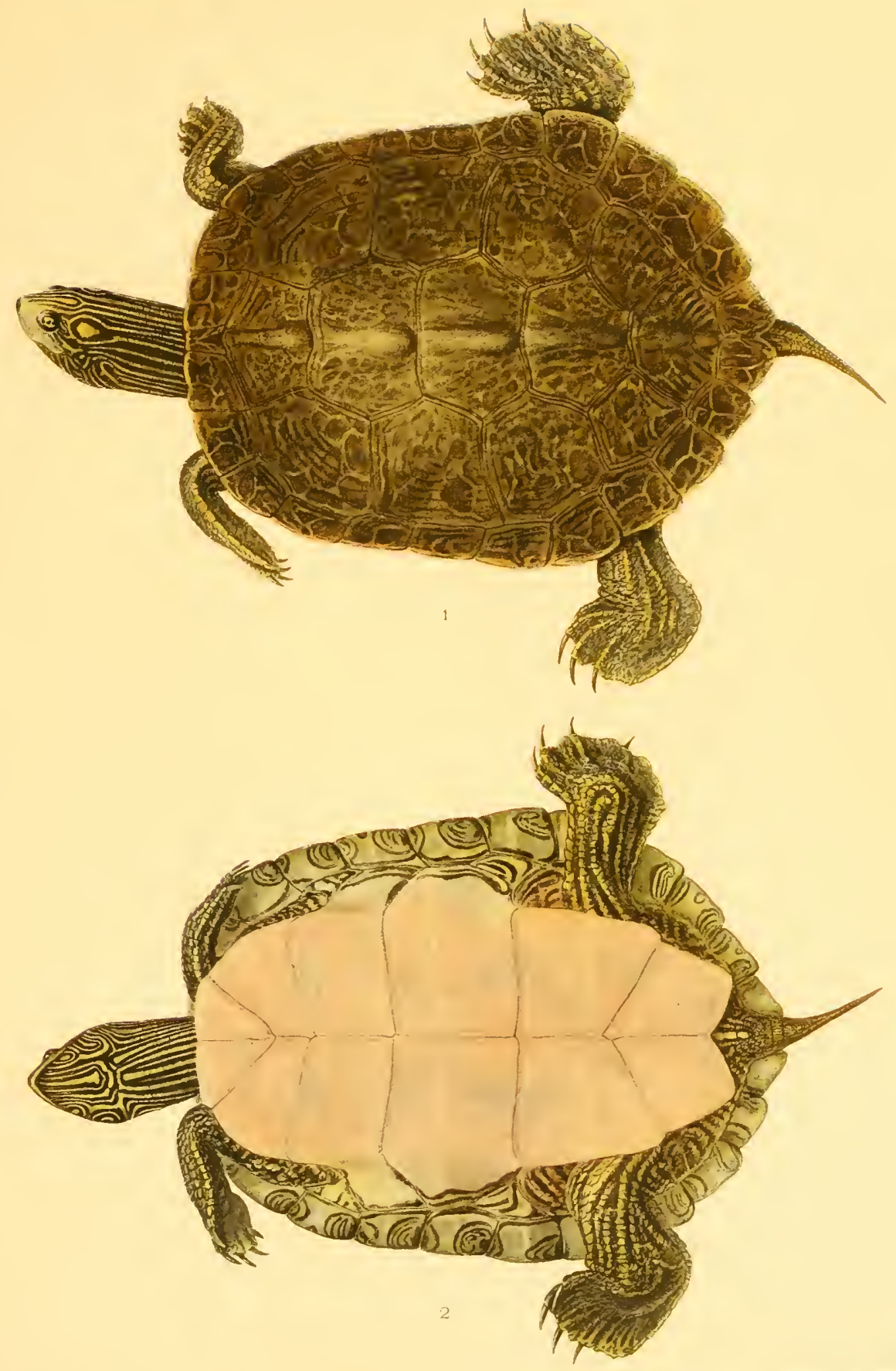
,

• 
PIATE 26. 
PLATE 26.

Diamond-Back Terrapin, Malaclemys rentrata concentrica (Shaw).

Fig. 1. Upper view. Fig. 2. Lower view.

From a male individual captured in Chesapeake Bay, and living in the New York Aquarium. 
Memoirs Boston SOC. NAT. Hist.. VOL. 8. No. 3.
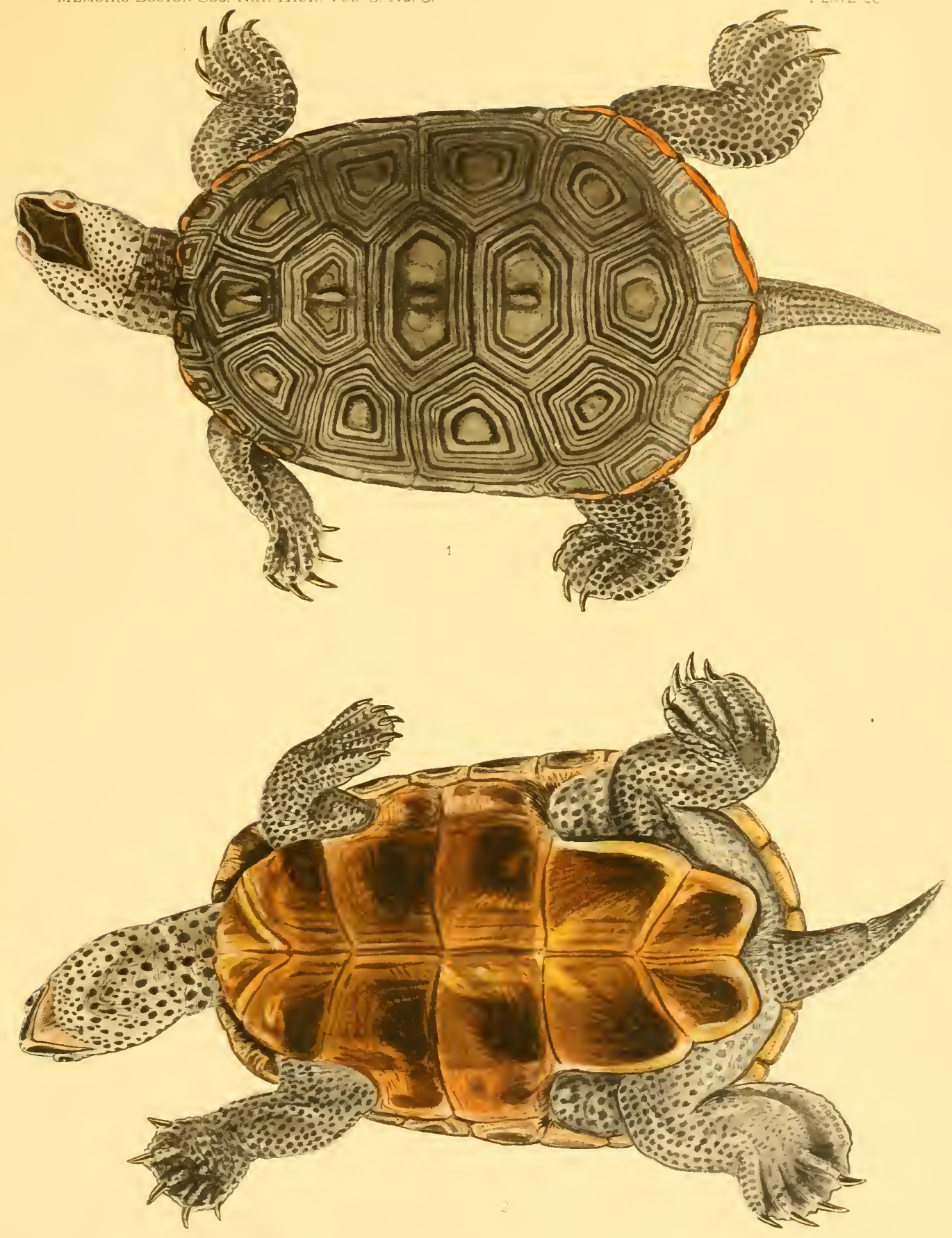
. 
PLATE 27. 
PLATE 27.

Spotted Turtle, Clemmys guttata (Schneider).

Fig. 1. Upper view. Fig. 2. Lower view.

The colors of the carapace are from a shell of a specimen taken in Sagamore, Cape Cod, Massachusetts; the soft parts are colored from a live male captured in New York City. 

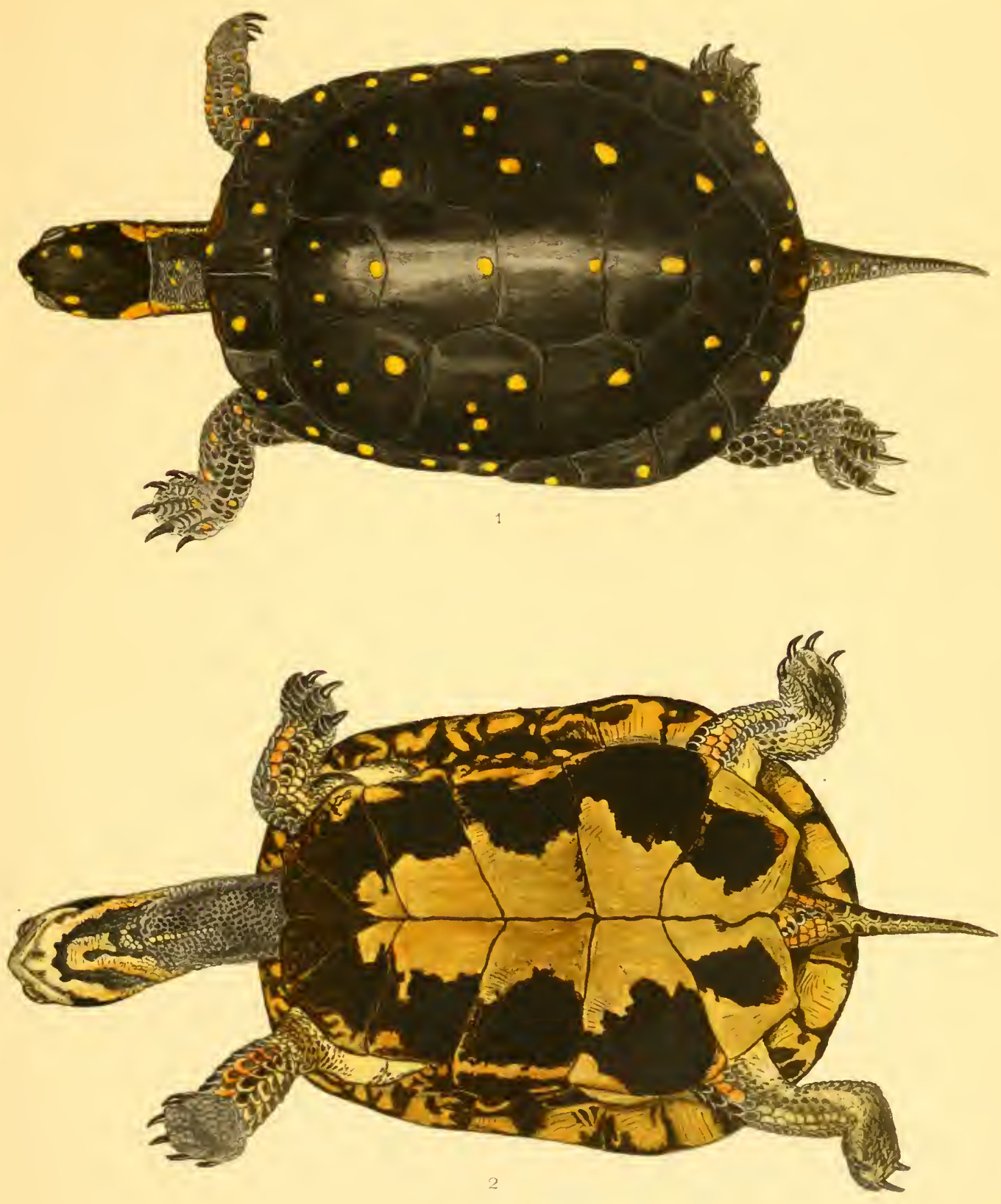

PLATE 28. 
PLATE 28.

Muhlenberg's Turtle, Clemmys muhlenbergii (Schoepff).

Fig. 1. Upper view. Fig. 2. Lower view.

From a living female belonging to the Zoölogical Society of Philadelphia, and presumably captured near that city. 

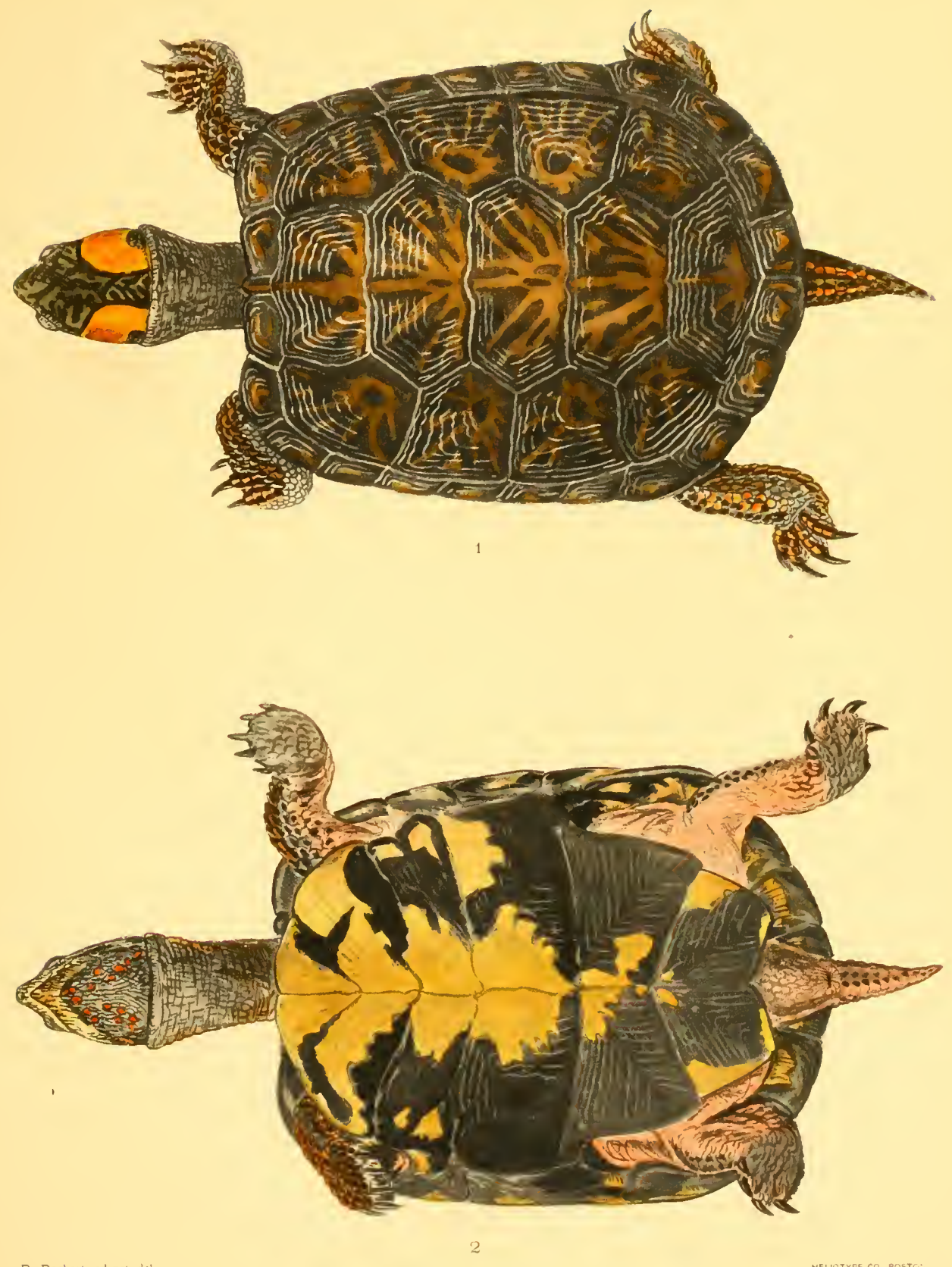

R. Deckert, ad nat, dol. 

PLATE 2 


\section{PLATE 29.}

Wood Tortorse, Clemmys insculpta (Le Conte).

Fig. 1. Upper view. Fig. 2. Lower view.

From a living male individual captured in Westchester County, New York. 

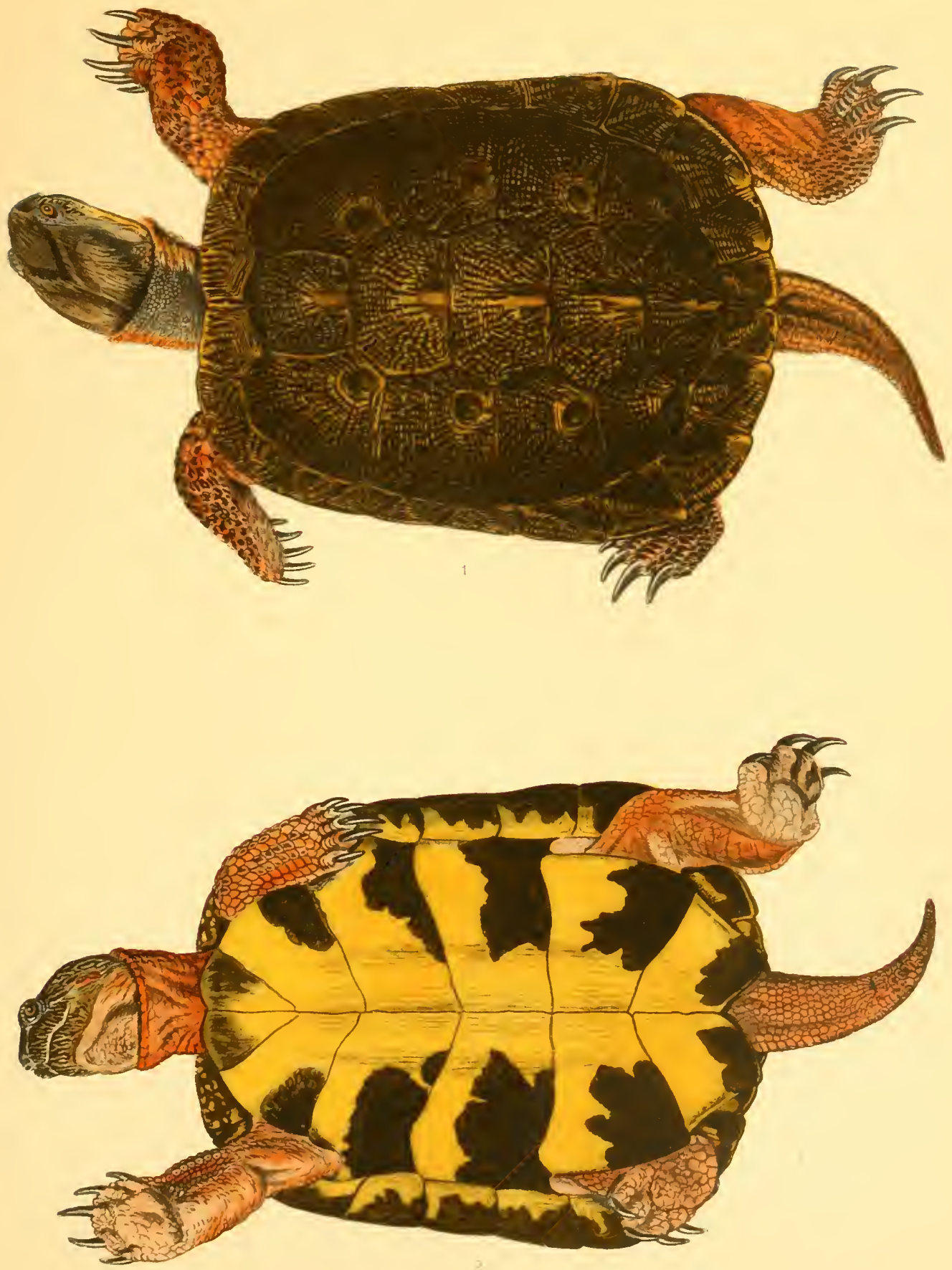

PLATE 30. 


\section{PLATE 30.}

Blanding's Turtle, Emys blandingii (Holbrook).

Fig. 1. Upper view. Fig. 2. Lower view.

From a living male individual captured at Venice, Ohio, and presented by Alexander Nielsen. 

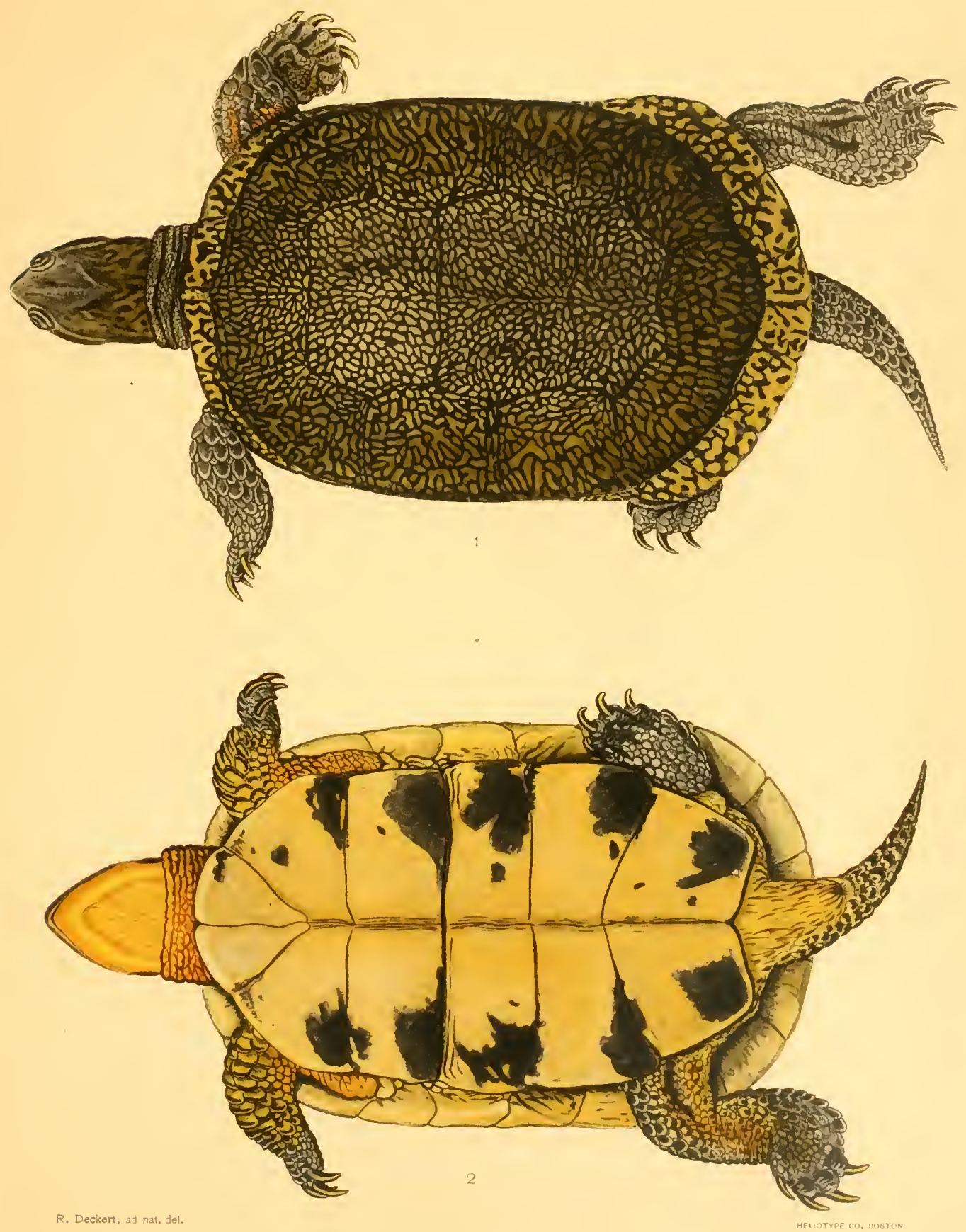

BLANDING'S TURTLE. 

PLATE 31. 


\section{PLATE 31.}

Box Tortorse, Terrapene carolina (Linné).

Fig. 1. Side view. Fig. 2. Lower view.

From a live female individual captured at West Barnstable, Cape Cod, Massachusetts. 

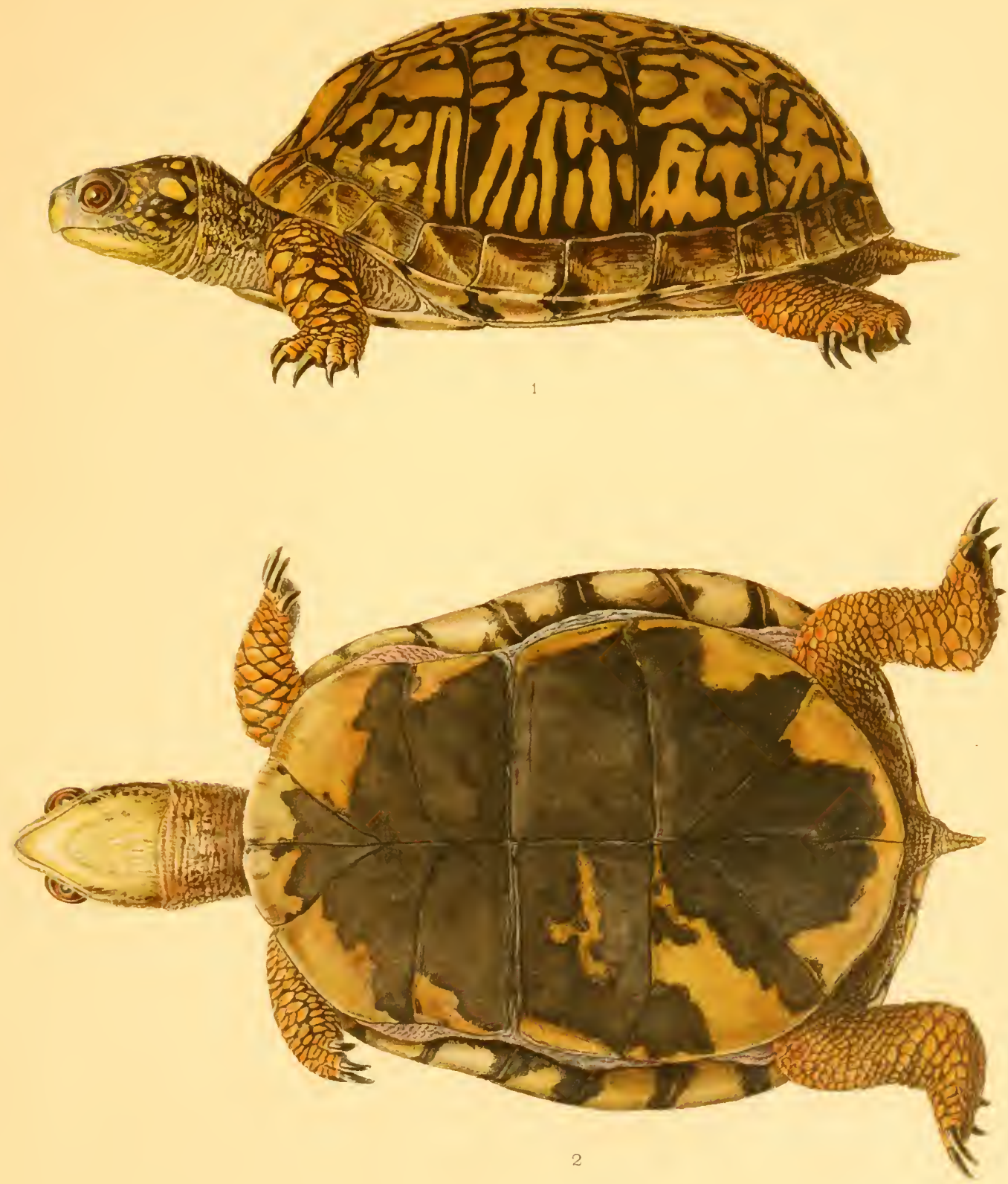

PLATE 32. 


\section{PLATE 32.}

Spiny Soft-shelled Tuntle, Amyda spinifera (LeSueur).

Fig. 1. Upper view. Fig. 2. Lower view.

From a living male individual in the New York Zoölogical Park. 

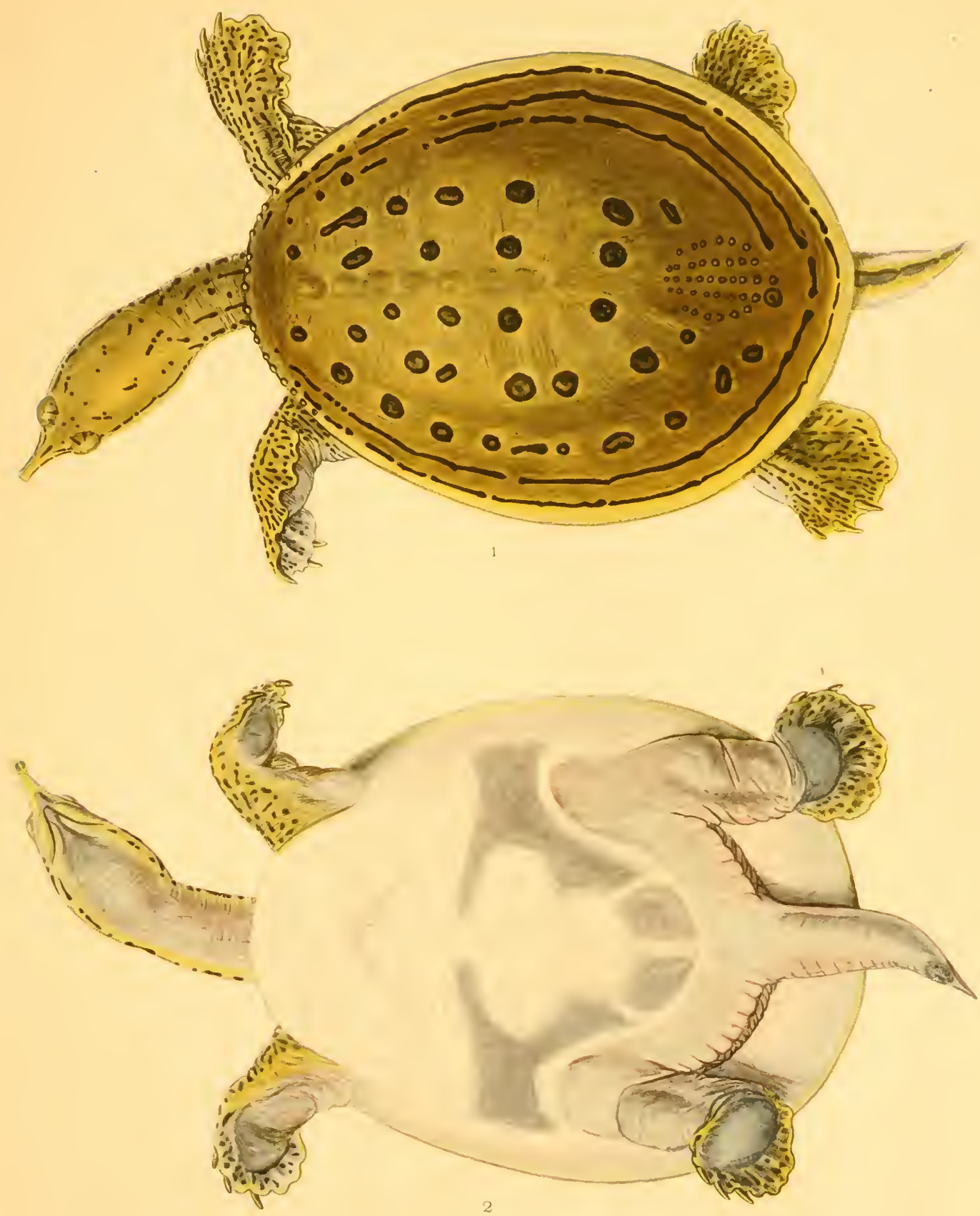







SMITHSONIAN INSTITUTION LIBRARIES

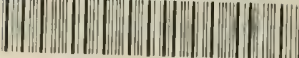

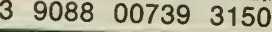

